\title{
DOE- -97008851 CONTENTS
}

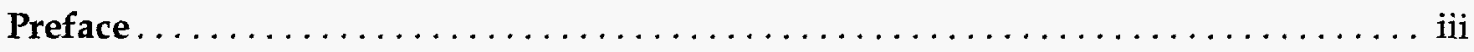

Introduction - Ushering in a New Era for the Department of Energy $\ldots \ldots \ldots \ldots \ldots v$ Fueling a Competitive Economy: The Department of Energy's

First Strategic Plan $\ldots \ldots \ldots \ldots \ldots \ldots \ldots \ldots \ldots \ldots \ldots \ldots \ldots \ldots \ldots \ldots \ldots \ldots \ldots$

The Critical Success Factors: Putting the Plan into Practice $\ldots \ldots \ldots \ldots \ldots \ldots$ viii

Strategic Alignment: Saving Taxpayer Dollars .................... viii

Reinventing Government: The Department's Contribution $\ldots \ldots \ldots \ldots \ldots$ ix

1. Energy Resources - Building a Bridge To a Sustainable Energy Future . . . . . . 1

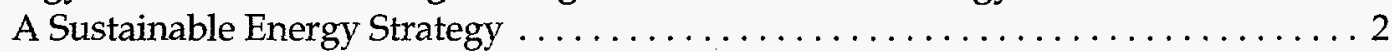

Partnerships To Develop More Efficient Vehicles $\ldots \ldots \ldots \ldots \ldots \ldots \ldots \ldots \ldots 2$

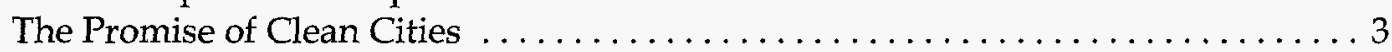

Innovative Partnerships for Climate-Friendly Technologies $\ldots \ldots \ldots \ldots \ldots \ldots 4$

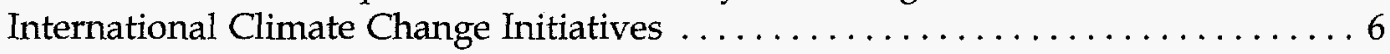

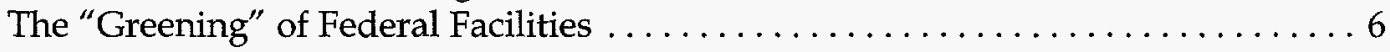

The Domestic Natural Gas and Oil Initiative ..................... 8

Government-Industry Cooperation To Expand Natural Gas Production . . . . . . . 10

The Strategic Petroleum Reserve: Restoring and Extending Its Readiness . . . . . . 10

Electric Power From U.S. Agricultural Products . . . . . . . . . . . . . . 10

The Next Generation of Nuclear Powerplants . . . . . . . . . . . . . . 11

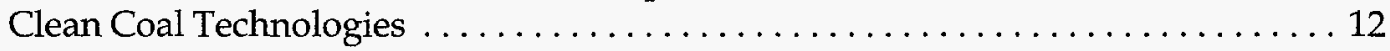

\section{Science and Technology - Providing the Knowledge That Drives}

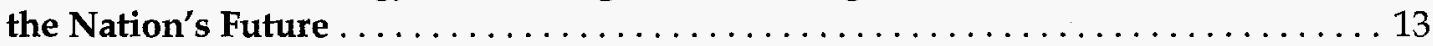

Scientific Excellence, Technological Leadership ..................... 13

Investigating the Causes of Global Climate Change . . . . . . . . . . . 15

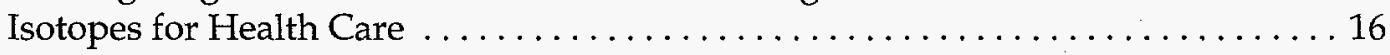

Peaceful Uses of the Atom: Proceeding With Caution $\ldots \ldots \ldots \ldots \ldots \ldots \ldots \ldots$

Commitment to Service and Performance at Our Science Facilities . . . . . . . . . 17

High-Performance Computing: Advancing the State of the Art . . . . . . . . . . 19

Science on the "Information Superhighway" .................... 20

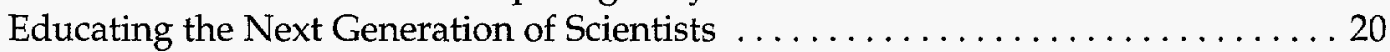

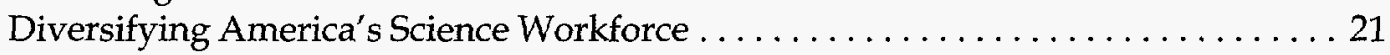

3. National Security - Reducing The Global Nuclear Danger.............. 22

A Safe, Secure, and Reliable Nuclear Weapon Stockpile . . . . . . . . . . . . 22

Continued Headway in Dismantling Warheads . . . . . . . . . . . . . . . 24

Leadership in Arms Control and Nonproliferation .................. 25 
Leading Worldwide Control of Weapon Materials .................. 25

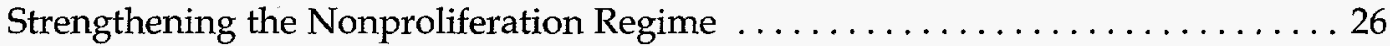

Management of Surplus Fissile Materials . . . . . . . . . . . . . . . . . 28

Naval Nuclear Reactors: 100 Million Accident-Free Miles . . . . . . . . . . . . . . . . . . 29

The Human Dimension of Our Changing Mission . . . . . . . . . . . . . . 29

4. Environmental Quality - Working Toward a Cleaner, Healthier Environment . . . . 31

The Challenge of the Cold War Legacy .......................... 31

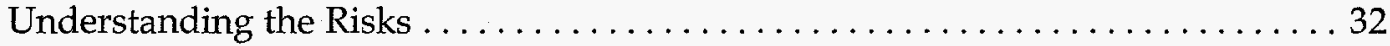

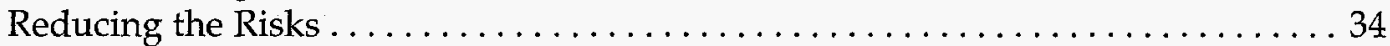

Innovative Environmental Technologies . . . . . . . . . . . . . . . 35

Efficiency Improvements in Environmental Management................ 35

Building Consensus on Waste Treatment . . . . . . . . . . . . . . . . 36

Pollution Prevention. . . . . . . . . . . . . . . . . . . . . . . . 37

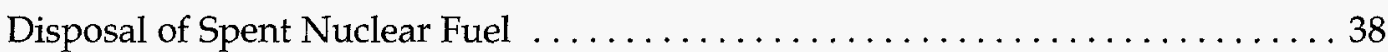

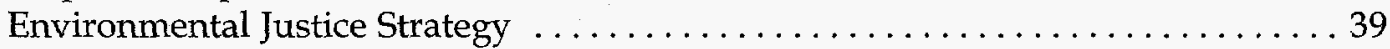

International Sustainable Development Agreements . ............... 40

5. Economic Productivity - Fueling a Competitive Economy $\ldots \ldots \ldots \ldots \ldots \ldots \ldots$

U.S. Energy Technology Exports and Investments . . . . . . . . . . . 41

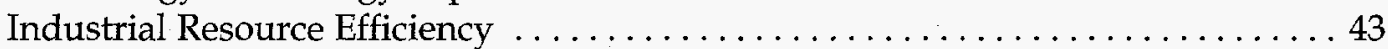

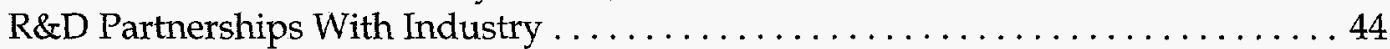



Industrial Use of Department of Energy R\&D Laboratories $\ldots \ldots \ldots \ldots \ldots \ldots 45$

Access for Small Business . . . . . . . . . . . . . . . . . . . . . . . 46

6. The Critical Success Factors - Assessing the Way We Do Business . . . . . . . 47

Communication and Trust: Establishing an Open Relationship

With the American People . . . . . . . . . . . . . . . . . . . . . . . . . . . . . 47

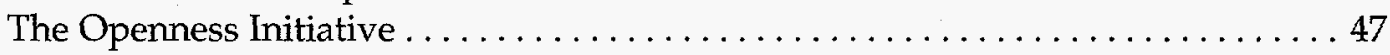

Improved Services to Customers and Stakeholders $\ldots \ldots \ldots \ldots \ldots \ldots \ldots \ldots 49$

Public Participation . ..................................... 49

Human Resources: Creating Meaningful Opportunities.................. 49

Toward a Streamlined Management Structure ...................... 49

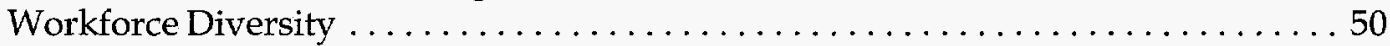

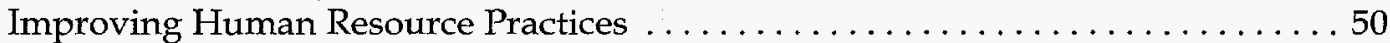

Environment, Safety, and Health: Protecting Workers, the Public,

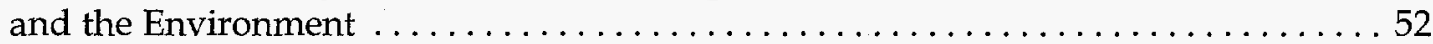

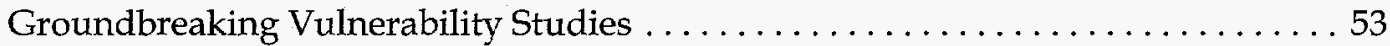

New Approach to Managing Hazards . . . . . . . . . . . . . . . . . . . 53

Streamlined Environmental Compliance ....................... 54

External Regulation of Department of Energy Nuclear Facilities . . . . . . . . . . 54

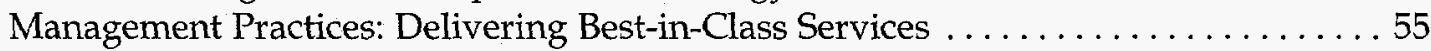

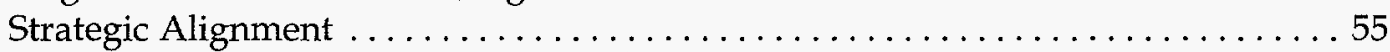

Contractor Accountability and Performance ..................... 56

Reduced Costs of Litigation ............................... 57

A 50 -Percent Cut in Internal Directives . . . . . . . . . . . . . . . . 57

The Quality Transformation: Becoming a World-Class Organization . . . . . . . 58

Alternative Uses of the Department's Lands and Facilities ................. 59

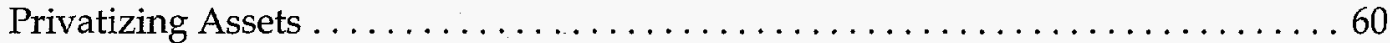

We Changed Our Priorities - Proceeding With Our Goals and Commitments .... 61 


\section{PREFACE}

The Department of Energy is delivering on the Clinton Administration's commitment to reinvent government by changing the way we do business. One of these changes is reflected in this new Annual Performance Report, which reports the Department's progress toward filling some of the Nation's most important needs in fiscal years 1994 and 1995. We have adopted strategic planning and performance measurement as the tools to clarify our goals, priorities, and commitments.

The title, Annual Performance Report, is itself an indicator of how we are reinventing the Department of Energy and adopting the principles of the President's National Performance Review. The predecessor to this document, The Secretary's Annual Report to Congress, was a more than 500-page document that reported activities by program and was not performance oriented. We wrote this new report with our customers in mind. It provides them with a readable progress report on how the Department is serving the country and doing it for much less cost. It reflects the integration of business lines and critical success factors that have been implemented throughout the Department.
The Annual Performance Report meets the requirements for agency annual reporting as stated in the Department of Energy Organization Act of 1977. It is also a forward-looking effort toward meeting the Government Performance and Results Act of 1993 reporting requirements, which begin with fiscal year 1999. We intend for future reports to also meet the requirements for an audited financial statement including results required by the Government Management Reform Act of 1994.

\section{How This Report Is Organized}

This Annual Performance Report is closely linked to the April 1994 Department of Energy Strategic Plan and the Secretary of Energy's Performance Agreement with the President for fiscal year 1995. The two earlier documents established goals and commitments for the Department, organized according to the Department's five business lines and the four critical success factors. This report describes our accomplishments during físcal years 1994 and 1995 relative to those goals and commitments, and it is therefore structured in the same way, Chapters 1 through 5 each focus on one of the business lines - energy resources, science and technology, national security, environmental quality, and economic productivity. Our performance related to the critical success factorscommunication and trust; human resources; environment, safety, and health; and management practices - is discussed in Chapter 6 . 
This page intentionally left blank 


\section{DISCLAMMER}

Portions of this document may be illegible in electronic image products. Imsges are produced from the best available original document. 


\section{INTRODUCTION \\ USHERING IN A NEW ERA FOR THE DEPARTMENT OF ENERGY}

In 1993, President Clinton challenged all Federal agencies to create a government that works better and costs less. Given the dramatic changes in the post-cold war world and our role as a major contributor to the Nation's economic strength, the Department of Energy realized that this challenge provided a tremendous opportunity to sharpen our mission focus and fundamentally rethink how we achieve our goals.

We have taken bold action to reshape our missions, priorities, and business practices. We now have a clearly defined vision for our contribution to the Nation's future. Using our unparalleled scientific and technological resources, we are making significant progress toward achieving our goals of improving the Nation's economic competitiveness, reducing the nuclear danger, enhancing national security, increasing energy efficiency, securing energy supplies, and protecting global environmental quality.

Over the past 50 years, the Department of Energy and its predecessor agencies have built an extensive network of national laboratory expertise in science and technology, including 30,000 scientists and engineers. We have a rich history in this area. We have supported the work of many Nobel Prize winners, including four of the five scientists who won Nobel Prizes in physics and chemistry in 1995. Research sponsored by the Department was also recognized with 28 "R\&D 100" awards in 1994 and 33 in 1995. These prestigious honors are awarded by a panel of science and technology experts and the editors of $R \mathcal{E} D$ Magazine to recognize the 100 most outstanding technology developments each year. Over the years, technologies developed through Departmental sponsorship have won more than 400 of these awards, known in the science community as the "Nobel Prize of new technologies." This is more than all other government agencies combined and more than twice as many as the top industrial sector winner.

The Department has supported the Nation's civilian R\&D for many years although our laboratory network was originally developed for and remained highly focused on national security efforts, specifically to fight the cold war. With the end of the cold war and the shift in our economy, we realized that now more than ever, our resources in science and technology are a critical component of U.S. industry's ability to compete in a global economy.

The Department has a unique role in using its assets to help industry compete. We understand better today the benefits of sustainable energy technologies, both to the economy and the environment, and have shifted our 
emphasis over the past 2 years to energy efficiency and renewable energy resources. There are tremendous opportunities in domestic and international markets for technologies in this area, and we have begun to focus on them.

The end of the cold war provided an opportunity for laboratory $R \& D$ to focus on making our economy more competitive, but our laboratory network remains as vital to our national security as ever before. The challenges today are different, however, and we have begun to change the application of our resources from nuclear testing and production of new weapons to sciencebased stockpile stewardship, nuclear weapons dismantlement, and nonproliferation of nuclear materials. The United States is committed to a ban on nuclear testing, yet we are still responsible for the maintenance of a safe and reliable nuclear deterrent, as well as of the technical competencies of our laboratories.

The end of the cold war has brought about yet another challenge: the estimated $\$ 300$ billion cleanup of the weapons complex, which consists of 130 sites in 33 States. The scope of the Environmental Management program, the single largest environmental program in history, is so enormous that determining the environmental and safety risks and the resources required to complete this program has become a monumental task itself. In the last 3 years, we have redirected our resources to reducing the highest risks first. In 1995 we completed 119 interim and 75 large-scale environmental actions at contaminated sites throughout the Department complex. A key component of our environmental management efforts is the technology development activities in our laboratories and through industry partnerships to clean up our sites and to reduce future risks and costs through waste minimization and pollution prevention. The new era of openness and two-way communication also means we are meeting the challenges of the cold war legacy through meaningful stakeholder involvement, including other Federal agencies, State and local governments, Native American nations, and citizens.

\section{Fueling a Competitive Economy: The Department of Energy's First Strategic Plan}

The Department of Energy, in partnership with our customers, is entrusted to contribute to the welfare of the Nation by providing the technical information and the scientific and educational foundation for the technology, policy, and institutional leadership necessary to achieve efficiency in energy use, diversity in energy sources, a more productive and competitive economy, improved environmental quality, and a secure national defense.

-Department of Energy Strategic Plan, April 1994

These words are the culmination of the first stages of the unprecedented strategic planning process in the Department of Energy that has taken place over the last 3 years. We realized that dramatic changes in the world required dramatic change in the Department's mission areas and management practices. This change could only be brought about by involving the Department's employees and external stakeholders in rethinking everything we do as a Federal agency.

The first comprehensive Strategic Plan in the Department of Energy's history emerged from the process that began with a meeting of the Department's senior leaders at the Motorola-Milliken 


\section{We have clarified and integrated the Department's business activities- with science and technology at the center of our vision}
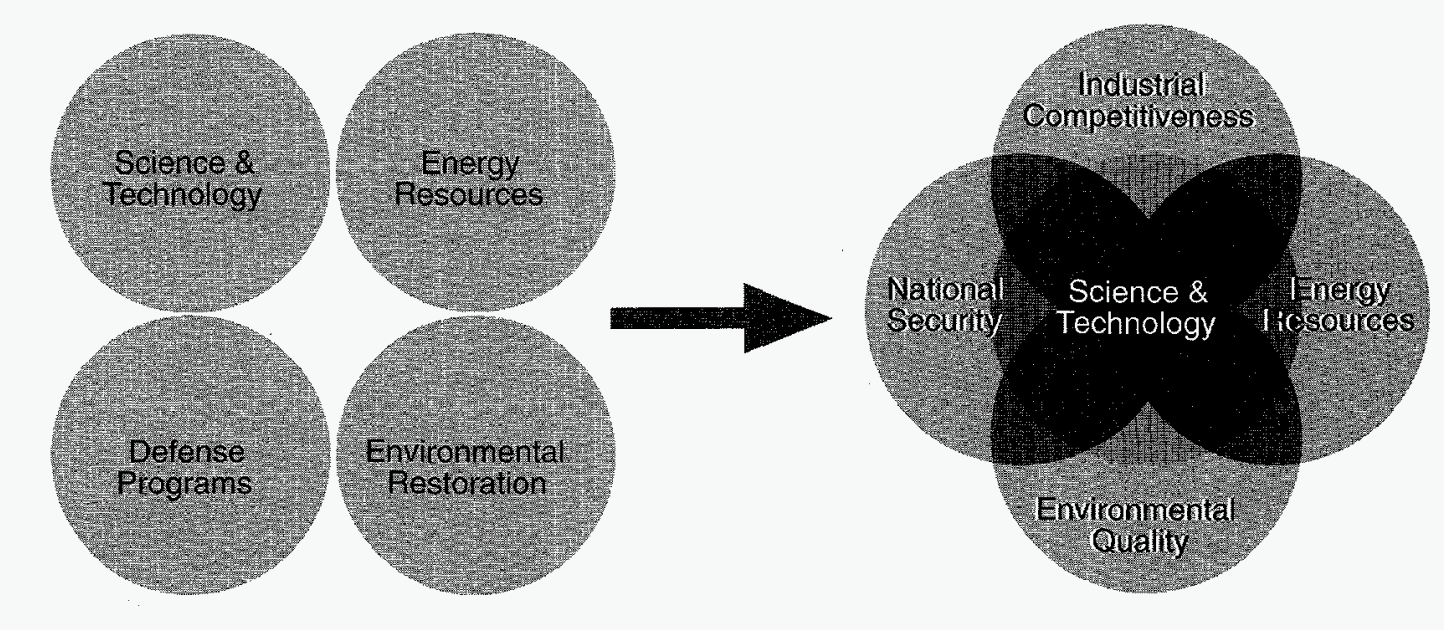

Quality Institute. The Plan, which was published in April 1994, provides the framework and shared vision for our missions in national security, energy resources, environmental quality, science and technology, and economic productivity. It is one component of our ongoing effort to integrate our business lines and clarify our vision, priorities, and strategies. The Department's following five business lines encompass and define our missions, which directly affect the security and the quality of life of every American:

- Energy Resources: Encourage efficiency and advance alternative and renewable energy technologies; increase energy choices for all consumers; ensure adequate supplies of clean, conventional energy; and reduce U.S. vulnerability to external events.

- Science and Technology: Use the unique resources of the Department's laboratories and the country's universities to maintain U.S. leadership in basic research; increasingly focus applied research to support the Department's other business lines; and maintain world technical leadership through longterm, systemic reform of science and mathematics education.

- National Security: Support and maintain the safety and reliability of the enduring stockpile without nuclear testing; safely dismantle and dispose of excess weapons; and provide the technical leadership for national and global nonproliferation activities.

- Environmental Quality: Reduce the environmental, safety, and health risks and threats from DOE facilities; and develop the technologies and institutions required for solving domestic and global environmental problems.

- Economic Productivity: Promote economic growth and the creation of high-wage jobs through research and development partnerships with industry; drive products into the domestic and international marketplace; and help industry become more competitive by costeffectively shifting from waste 


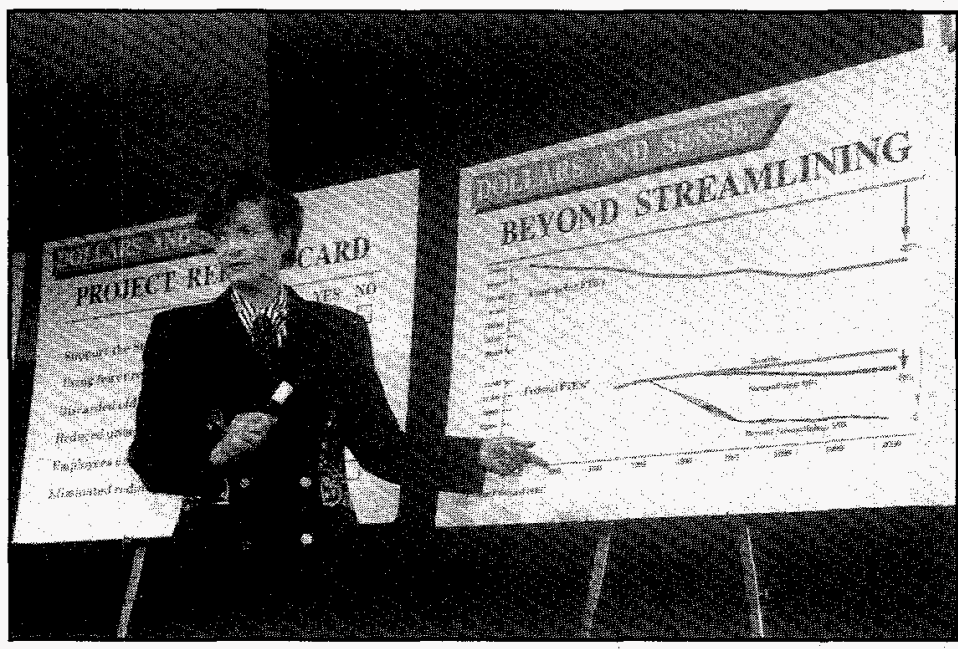

Secretary O'Leary discusses the Department's Strategic Alignment at a Departmental "all hands" forum.

management to resource efficiency and pollution prevention.

\section{The Critical Success Factors: Putting the Plan into Practice}

The Department is strongly committed to using the principles and tools of quality management to improve our services and reduce our costs so that we may better serve the American people. We recognized that achieving the goals of the Clinton Administration required changing not only what we do, but also how we do business. We identified four factors that we integrated into our five business lines to realize our vision and to be successful in our mission. These four factors will determine how effective we are in each of our business lines:

- Management Practices: We must implement the best practices in allocating, spending, and accounting for resources and procuring, producing, and contracting for goods and services.

- Communication and Trust: We must communicate information and build trust within the organization and with our stakeholders and customers.

- Human Resources: We must recruit, train and develop, reward performance, motivate, and promote diversity within our workforce.

- Environment, Safety, and Health: We must ensure the safety and health of workers and the public, and we must protect and restore the environment.

We realized during the strategic planning process that our plan for the Department can only prove successful through the efforts of all our employees. Together we developed a set of core values that have driven our efforts in fulfilling our mission. These values, such as customer-orientation, commitment to excellence, respect for the environment, and regard for teamwork, have defined our new culture and commitment to the American people we serve.

\section{Strategic Alignment: Saving Taxpayer Dollars}

In December 1994, Secretary O'Leary announced that the Department's budget would be reduced by $\$ 14.1$ billion over the next 5 years to help the President fulfill his pledge to reduce the deficit and cut taxes for middle-class Americans. This plan has since been revised to reduce the budget by $\$ 10.5$ billion to reflect the decision not to sell the Alaska Power Administration. We are achieving most of this goal through reductions in Environmental Management and applied energy programs and through savings in the Department's laboratory complex.

A significant portion of these reductions results from a major package of initiatives that include organizational 


\section{We are taking a systematic approach to making sweeping changes in the Department}
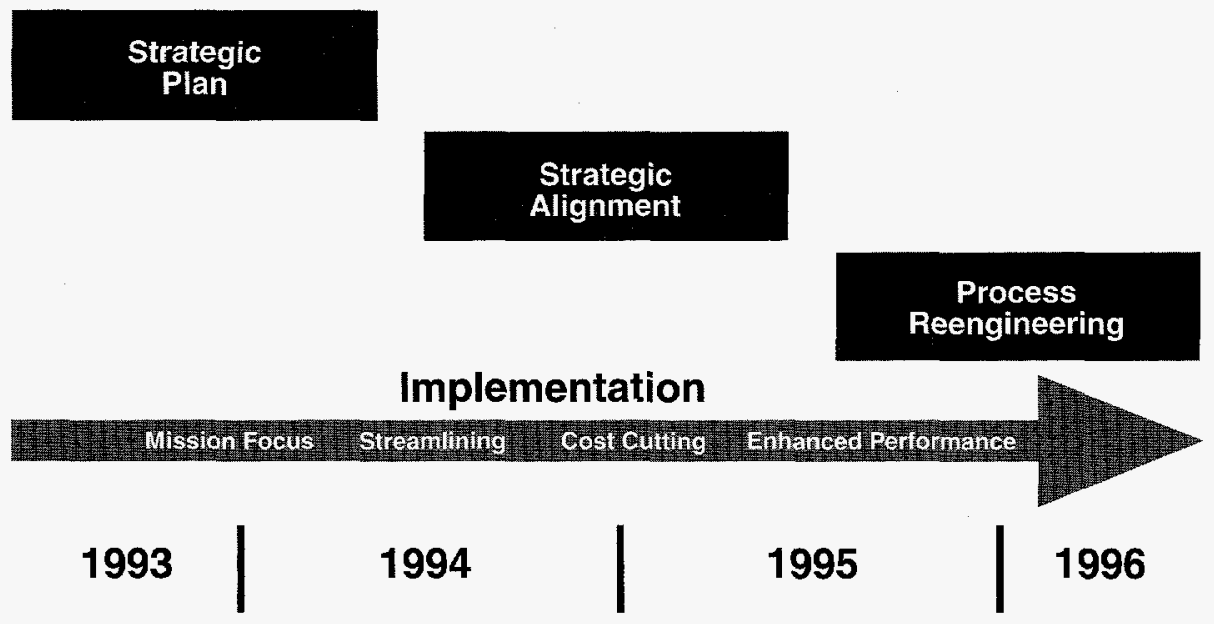

reforms, privatization, and cost-cutting measures. In 1995, we entered into a collaborative effort to align our programs strategically to achieve greater efficiencies and cost savings in support of our key missions. In May 1995, following months of intensive review by a team of Department of Energy employees, Secretary O'Leary released the plan for the Department's Strategic Alignment. She announced that alignment of the Department's programs and changes to our management practices alone could save more than $\$ 1.7$ billion.

\section{Reinventing Government: The Department's Contribution}

The Department's Strategic Plan and Strategic Alignment have brought about sweeping changes to provide more for less. The driving theme for these changes has been this Administration's commitment to reinventing government.
Part of the Administration's plan to reinvent government is the development of a performance agreement between each Cabinet Secretary and the President. The Department's first Performance Agreement, signed by the President, Secretary O'Leary, and the Department's Secretarial Officers in 1995, contained 59 commitments and 133 performance measures. We have tracked our progress against these commitments and performance measures. The Performance Agreement is becoming a valuable tool for setting performance goals for the agency and establishing our commitments to the American people.

The Vice-President's Hammer Award recognizes excellence in agency efforts to reinvent government in support of the President's National Performance Review principles: putting customers first, cutting red tape, empowering employees, and getting back to basics. The Department of Energy has earned 


\section{Hammer Awards for Innovative Efforts to Reinvent Government}

In 1994, a Hammer Award was earned for the Chief Financial Officer's streamlining of financial management services to save more than $\$ 1$ million annually. In 1995, an award was given for a cooperative effort between our Oak Ridge Operations Office and Lockheed Martin Energy Systems for saving about $\$ 390$ million through more than 350 cost-savings projects completed since 1993. The Bonneville Power Administration received an award for cutting its projected costs over the next 5 years by more than $\$ 500$ million annually so that it can offer competitive and stable prices to its custamers. Af the Albuquerque Operations Office, the Uranium Mill Tailings Remedial Action Team received an award for the saving or cost avoidance of more than $\$ 70$ million fhrough hundreds of ideas implemented since 1988. A fifth award was given in 1995 to the "EM Change Gang," 11 Department employees who organized, conducted, and coached an Environmental Management Program Change Summit that resulted in commitments to save more than $\$ 200$ million through productivity improvements. Finally, a sixth award was presented to the Departments of Commerce and Energy in recognition of the innovative use of another Federal agency's equipment and staff 10ak Ridge's Y-12) for delivery of a National Instifule of Standards and Technology (NIST) calibration service that NIST could not otherwise provide. Before the establishment of this service, key U.S. manufacturing companies had to rely on a foreign national laboratory for this high-accuracy calibration service. $Y-12$ is performing this service at a lower cost and in half the time.

six Hammer Awards since adopting the Clinton Administration's promise of a government that produces more for less money.

The efforts that have earned Hammer Awards are but a few of the many changes that our employees have taken the initiative to make happen. As we proceed with our efforts in 1996, we will continue to contribute to the Clinton Administration's objectives through a focus on our mission priorities, customer service, and reinvention of government to achieve greater results for less cost to the American taxpayer. 


\section{ENERGY RESOURCES BUILDING A BRIDGE TO A SUSTAINABLE ENERGY FUTURE}

The ever-increasing demand for energy services throughout the U.S. economy and the world shapes the Department of Energy's mission of developing new and improved energy technologies. If current trends persist, U.S. oil imports will continue to rise, our Nation's annual trade deficit in oil will more than double by 2010, and the Persian Gulf will achieve its highest share ever of the world oil market - all of which point to potentially significant economic and security concerns. Moreover, rapidly growing energy demand worldwide is expected to exacerbate problems with urban air quality and global climate. Fortunately, new energy supply and demand technologies and fuel substitution can reduce the Nation's vulnerability to supply disruptions and dramatically improve environmental quality, both domestically and worldwide.

The Department is working with industry to develop and deploy energyefficient and renewable energy technologies and to advance the efficient

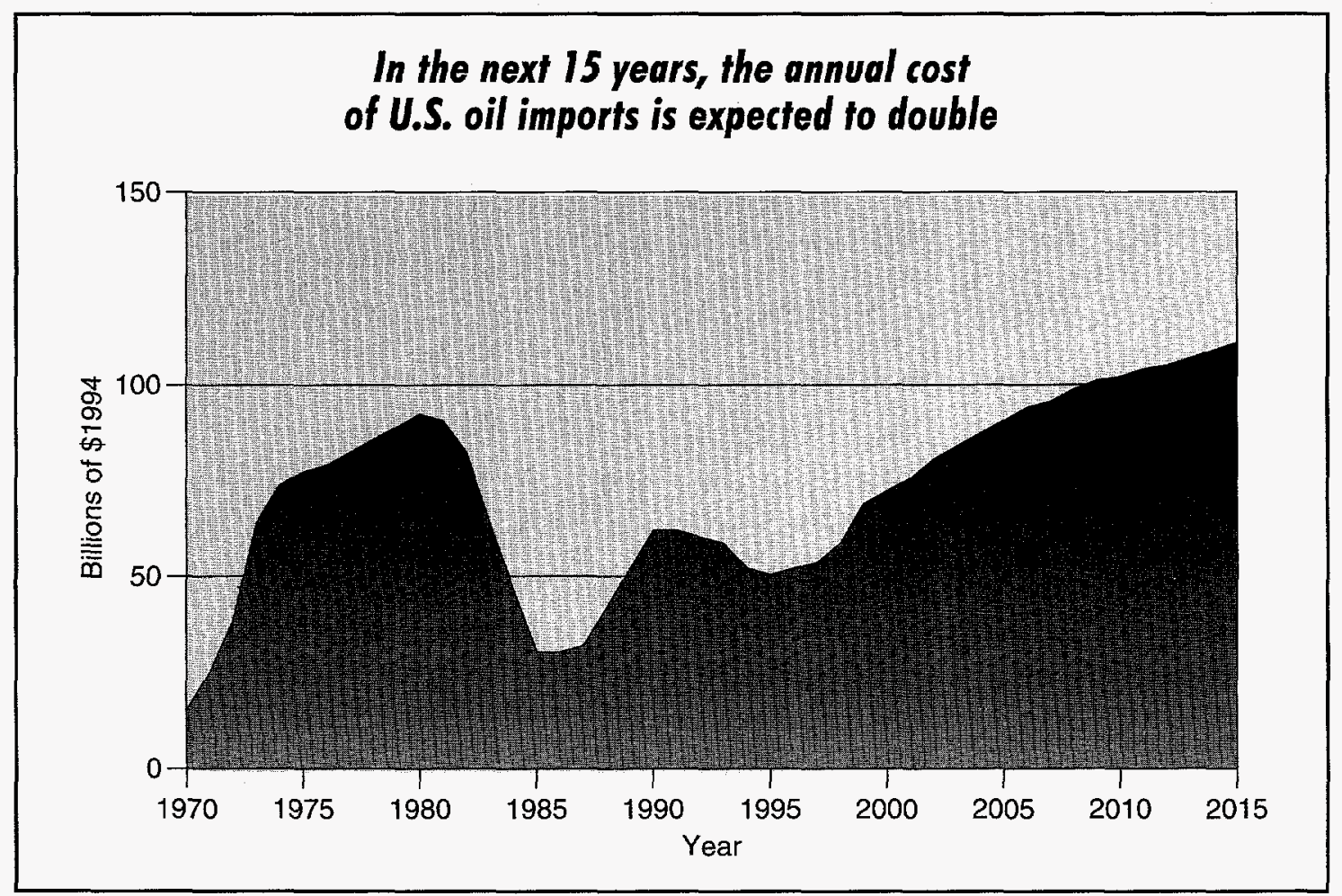


and environmentally responsible production and use of conventional energy sources. Our vision is for the United States to be a worldwide leader in developing, using, and exporting sustainable, environmentally attractive, and economically competitive energy systems. We seek to have in place a flexible, clean, efficient, market-based system of energy supply and end-use, with minimum vulnerability to disruption.

\section{A Sustainable Energy Strategy}

The Department's energy mission and priorities are guided by the Administration's long-term National Energy Policy Plan, which the President transmitted to Congress on August 4, 1995. Entitled Sustainable Energy Strategy: Clean and Secure Energy for a Competitive Economy, the plan identifies three goals of sustainable energy policy: maximizing energy productivity,

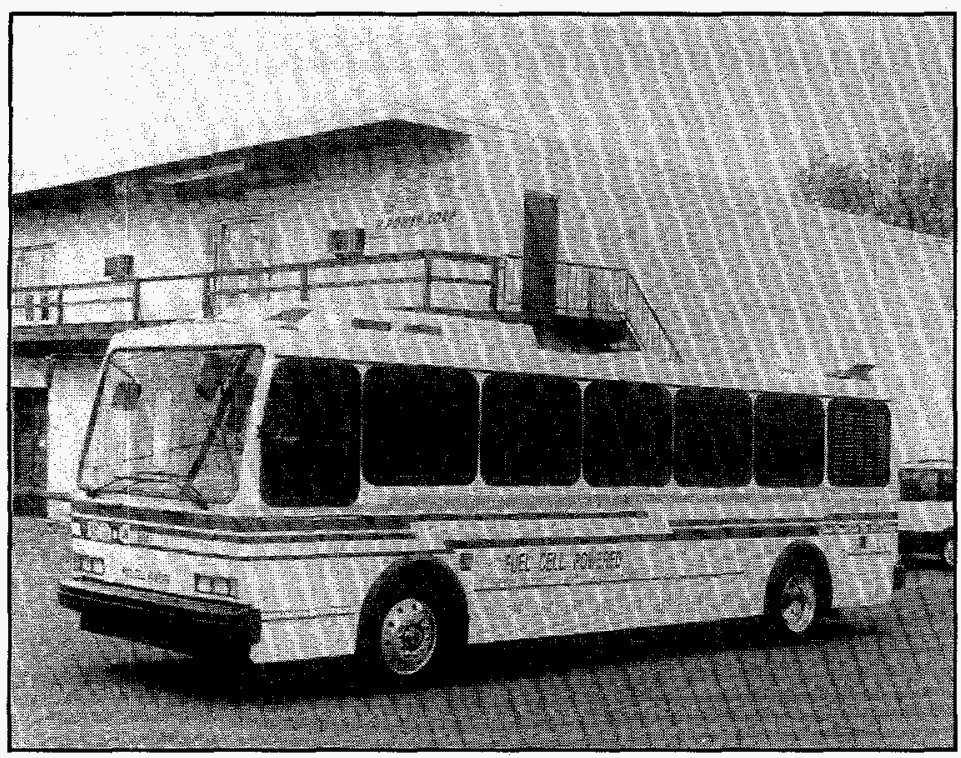

This bus was developed by $H$. Power Corporation of Belleville, New Jersey, for DOE as part of the fuel cell bus project. Fuel cells produce electricity by combining hydrogen and oxygen atoms. Since they have no moving parts, they produce little or no noise. Except for ordinary water, they produce near zero emissions and can offer the same performance as conventional gasoline and diesel fueled vehicles. preventing pollution, and keeping America secure. The following five strategies were developed in 1995 to deliver on these goals:

- Increase the efficiency of energy use

- Develop a balanced domestic energy resource portfolio

- Invest in science and technology

- Reinvent environmental protection

- Engage the international market

The Department developed the 1995 National Energy Policy Plan with extensive stakeholder involvement across the Nation. In August 1994, Secretary $\mathrm{O}^{\prime}$ Leary held a town meeting in Washington, D.C., to kick off the national effort to seek public input. The interagency development process included 8 regional town meetings held around the country and featured 16 panels of experts who advised on energy policy.

\section{Partnerships To Develop More Efficient Vehicles}

Radically improving the energy efficiency of transportation is vital to lowering the Nation's high consumption of imported oil and reducing pollution. The Department continues to emphasize the development of technologies that could significantly increase automobile fuel economy. We are spearheading a joint industry-government effort to develop a clean, fuel-efficient car capable of traveling 80 miles on a gallon of gasoline. The goal is to demonstrate a prototype by 2004 . In February 1995, the research and development plan for this "Partnership for a New Generation of Vehicles" was completed, and the industry engineering design team was established in March.

We have been carrying out promising work on hybrid propulsion systems, 
automobile fuel cells, ceramic and aluminum components, and heavy-duty diesel engines. The Department, General Motors, and Ford progressed through the second year of cost-shared efforts to develop hybrid automobile-propulsion systems that will improve fuel economy, meet future emission standards, and support the use of alternative fuels. In cooperation with two of our industrial partners, Tecogen and United Parcel Service (UPS), the Department developed and gained certification in 1995 for a 4.3-liter natural-gas-powered truck engine with ceramic components that already meets the 1998 ultra-lowemissions performance standard for heavy-duty engines. In 1996, UPS will expand its fleet of alternative-fuel trucks with 276 of these new natural gas engines.

To accelerate development of fuel cell propulsion systems for light-duty vehicles, the Department was instrumental in the December 1994 formation of the Fuel Cell Alliance. Stakeholders in this governmentindustry alliance include domestic automakers, component suppliers, fuel cell developers, national laboratories, universities, and the fuels industry. In conjunction with the Department, the automotive industry establishes program policies, identifies precompetitive $R \& D$ priorities, sets intellectual property guidance, and reviews technical progress. Under costshared research projects with the Department, each of the three major U.S. automakers is pursuing different technical approaches, utilizing its own vehicle design, data, and analysis methods. A key additional element of the alliance is the Department's coordination of precompetitive $R \& D$ that is intended to resolve fundamental issues associated with fuel cells and ancillary components that apply to different fuel cell propulsion systems.

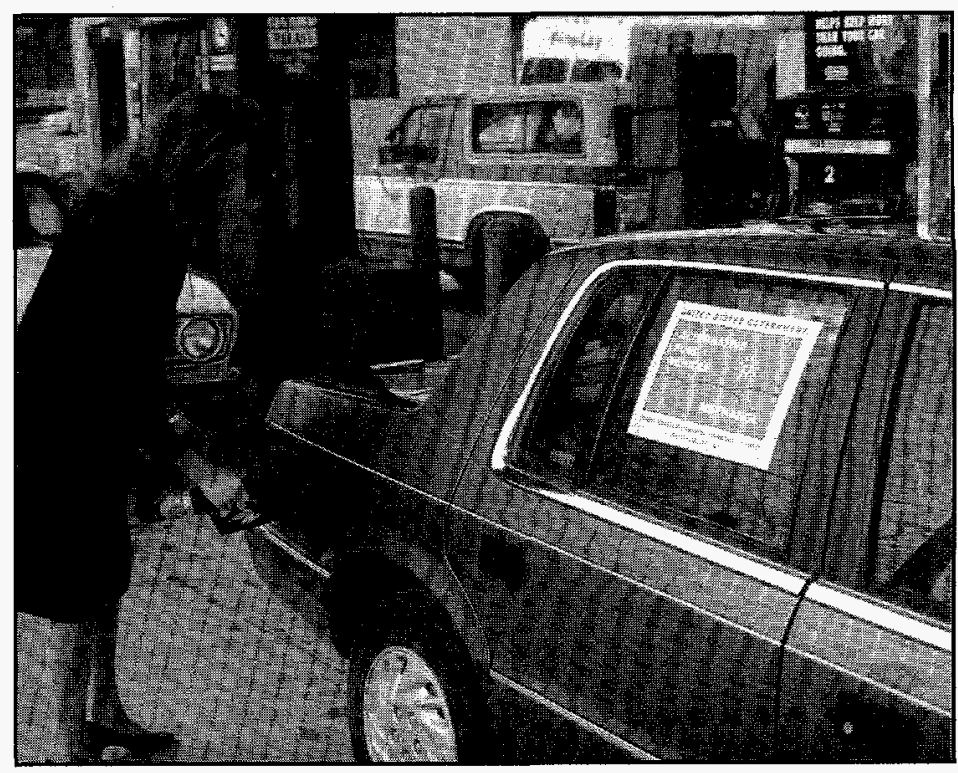

An employee of the National Renewable Energy Laboratory (NREL) refuels a government car with methanol. The Clean Cities campaign aims to develop fueling stations, repair service stations, and other infrastructure necessary to support the use of alternative-fuel vehicles.

Each automaker team will have access to the technology and products resulting from precompetitive $R \& D$.

The United States Advanced Battery Consortium, consisting of the Big Three U.S. automakers and DOE, is now in its sixth year and is placing increased emphasis on long-term lithium polymer batteries. The Consortium is working toward a Phase II cooperative agreement that will cover these activities for the next 4 years. The Consortium's role has become more important in view of the recent agreement between the automakers and the State of California emphasizing advanced battery development.

\section{The Promise of Clean Cities}

Use of low-cost, clean, domestic transportation fuels also can counteract the drawbacks of importing oil, while reducing urban air pollution and greenhouse gas emissions. 
Clean Cities is a locally based government-industry partnership, coordinated by the Department to promote the use of alternative transportation fuels. By combining local decision-making with the voluntary action of partners, the "grass-roots" approach of Clean Cities departs from traditional top-down Federal programs. The program works with local officials to develop a plan that will create a sustainable nationwide alternative-fuels market. The Department is working with Clean Cities coalitions nationwide to create new jobs and commercial opportunities, facilitate alternative-fuelvehicle (AFV) production and conversion, expand local refueling infrastructure, develop "Clean Corridors," increase public awareness, and advance clean air objectives.

By the end of 1995, 43 Clean Cities were involved in the program, reaching as far as Hawaii and across the border to Mexico, representing almost 1,900 stakeholder organizations.

In 1995, a total of $45,000 \mathrm{AFVs}$ (including 5,000 Federal AFVs) were added to Clean Cities locations exceeding the 25,000 goal for the year. These vehicles displaced up to 0.8 million barrels of oil during the year.

In 1995, the Department held the first national Clean Cities conference, which addressed the real life challenges of owning and operating AFVs and sought program strategies to assist Clean Cities stakeholders to overcome related obstacles. We also published the first Clean Cities Guide to Alternative Fuel Vehicle Laws and Incentives, which provides potential AFV operators with a checklist of funds available to reduce AFV purchase costs.

We partnered with Chrysler Corporation in 1995 to use the Clean Cities network to promote natural gas vehicles and supporting refueling infrastructure in targeted local markets. Ultimately, the goal of this long-term sales and marketing effort is to secure 50 percent of the van and pickup fleet market for natural gas vehicles.

\section{Innovative Partnerships for Climate-Friendly Technologies}

The Department has been playing a major role in launching the President's Climate Change Action Plan. We are implementing 26 of the actions contained in the plan in an effort to meet Energy Policy Act of 1992 mandates and to help meet the U.S. commitment under the Framework Convention on Climate Change to reduce U.S. greenhouse gas emissions. Our goal is to reduce these emissions in the United States to 1990 levels by the year 2000 .

Since 1993, the Department's Climate Change programs have fostered joint efficiency and renewable energy efforts with hundreds of small, medium, and large businesses, municipalities, States, and other Federal agencies. The programs rely largely on voluntary partnerships driven by our partners rather than on directives from Washington. They have proven to be flexible enough to meet the diverse needs of customers across the Nation while focused enough to achieve U.S. economic and environmental goals.

Even though funding levels for most programs have been lower than originally anticipated, several programs are meeting partnership and other goals, such as dollars saved from energy saved, jobs created, and pollution prevented. Many others are performing at a higher level than expected given the funding cutbacks. 
As of June 1996, the Department received 108 participation accords from electric utilities pledging to reduce greenhouse gas emissions by the year 2000. These agreements represent 567 of the 800 utilities that have expressed interest in the Climate Challenge program, a voluntary program developed by the Department and the electric utility industry. Sixty-one percent of 1990 electric collaboratives attracted utility participation that will result in new renewable energy supply for the Nation.

In the buildings sector, the Department's Rebuild America program awarded six regional partnership teams a total of $\$ 4.29$ million to make energyefficiency improvements. The U.S. Conference of Mayors accepted the Rebuild America Energy Smart Challenge and obtained commitments from mayors of 28 cities to develop action plans for community-wide building energy-efficiency improvements.

In the area of technology introduction, we launched our Energy Saver initiative with major appliance retailers, including Sears, Montgomery Ward, Home Depot, and Circuit City. Another partnership launched in 1995 with the National Association of Energy Service Companies is anticipated to save building owners as much as $\$ 700$ million per year in energy costs by the year 2000. The Department and the energy service companies will encourage building owners to reduce their energy use and save money by investing in energy-efficient equipment. The goal is to reduce annual U.S. energy consumption by an amount approximately equal to all the gasoline consumed in the United States during a two-and-a-half-day period.

The Department has also been working with States to expand energy-efficiency

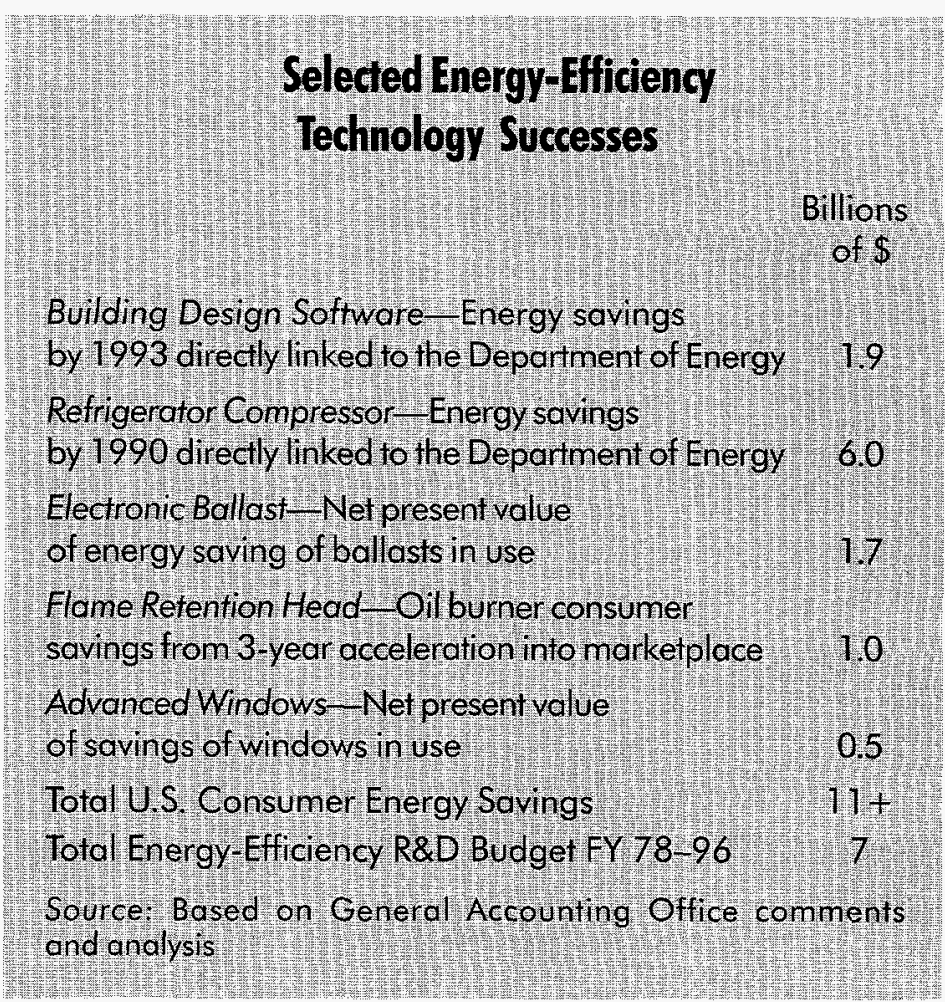

and renewable energy activities across all energy-use sectors. In 1995, each State Energy Program dollar leveraged $\$ 11$ in non-Department of Energy funds. We have also been aggressively transferring proven energy-efficiency measures to reduce energy use and energy costs in low-income homes, schools and hospitals. We exceeded our 1995 goal by weatherizing 118,000 lowincome homes, upgrading 1,455 schools and hospitals, and employing 13,000 people.

Through the Motor Challenge program, the Department and industry have been promoting the adoption of a systems approach to developing, purchasing, and managing motors, drives, and motor-driven equipment. The program's 1995 membership goal was 300 - but 1,000 companies enlisted. Our National Industrial Competitiveness for Energy, Environment, and Economics program funded 17 projects with 1995 funds to produce the next wave of cost-effective, pollution-prevention technologies that will spawn further innovation as project 


\section{Industry's rapidly increasing participation in the Climate Wise program will significantly reduce future greenhouse gas emissions}

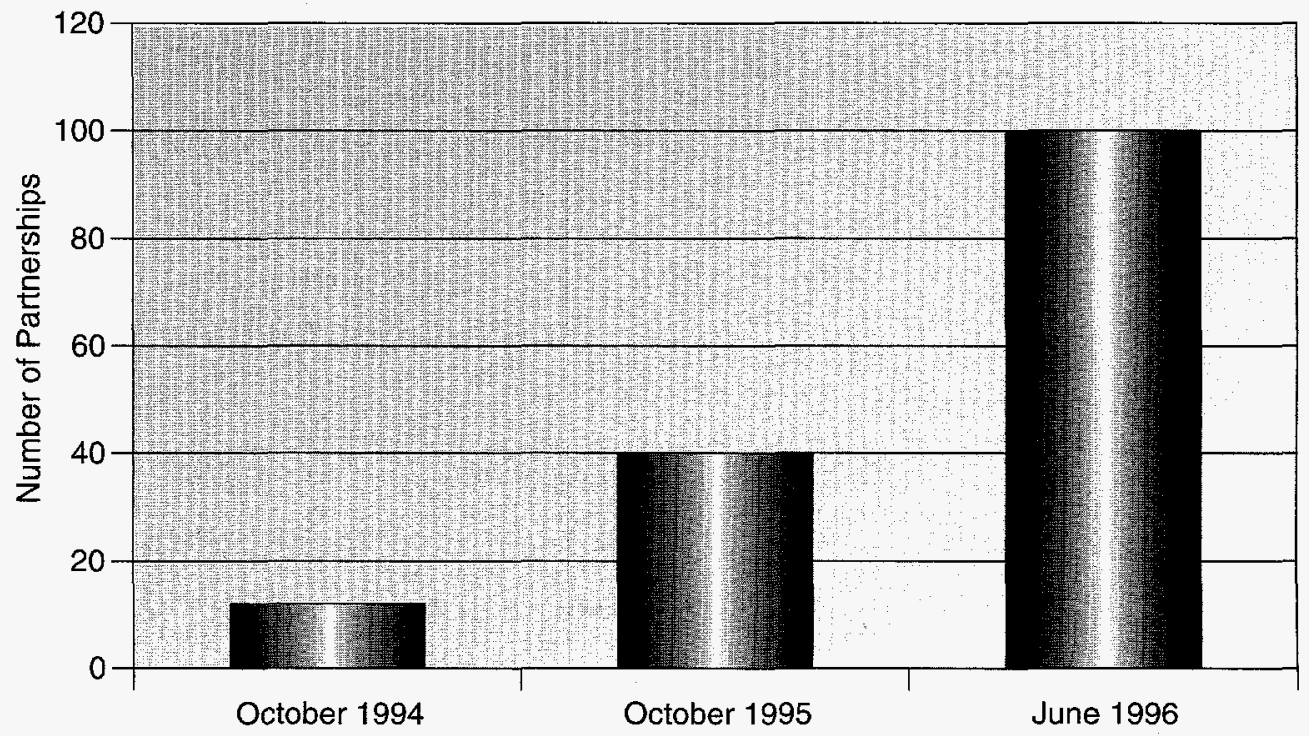

successes come to fruition. The overall industrial greenhouse gas reduction program, Climate Wise, received 40 pledges from industry in 1995 to reduce emissions significantly over the next several years.

\section{International Climate Change Initiatives}

The Department has completed development of guidelines and established the data collection system for voluntary reporting on greenhouse gases emitted in the United States. We issued the guidelines on October 20 , 1994, and the Energy Information Administration's information management system for receipt and storage of voluntary submissions became operational on July 21, 1995. The first reporting period closed October 31, 1995.

Working with the Environmental Protection Agency, the Department formally established the U.S. Initiative on Joint Implementation (USIJI) to further U.S. goals under the Climate Change Treaty. Joint implementation is a mechanism by which parties share emission-reduction activities. On January 27, 1995, seven USIJI projects plus eight other potential USIJI projects were selected. Several international and domestic workshops were conducted to broaden participation in the program. In response to a second solicitation in July, 21 proposals were received.

\section{The "Greening" of Federal Facilities}

As a major energy user itself, the Federal Government must take the lead in using innovative energy technologies and approaches that reduce costs and pollution. To help reduce the intensity of energy use in Federal facilities by 30 percent by 2005 (relative to the 1985 level), the Department has begun to facilitate the transfer of energy-efficient and environmentally sound technologies used in the "Greening of the White House" to all Federal buildings. "Greening" is a comprehensive 
energy and environmental assessment process involving many partners that results in specific recommendations and an action plan.

During 1995, the Department initiated three new Federal "Greening Models": the Pentagon, the Presidio in San Francisco, and the Forrestal Building in Washington, D.C. The Pentagon recommendations were completed. The Federal Energy Management Program (FEMP) assisted agencies in developing and implementing six (doubling from three) energy-savings performance contracts and attracted $\$ 21$ million in private-sector investments in Federalsector energy projects.

In a White House ceremony on September 12, 1995, highlighting "Environmental Excellence in Government," more than 22 Federal agencies signed the Energy Efficiency and Resource Conservation Challenge. Conceived by the Department and co-sponsored by the Environmental

\section{Making the Department's Own Buildings More Energy Efficient}

At the Department of Energy's own headquarters buildings, we implemented measures that have reduced energy consumption by 20 percent from the 1985 baseline, 5 years ahead of the deadline mandated by the Energy Policy Act of 1992 (EPACT). Headquarters energy consumption was down 19.6 percent in $F Y 1994$ and 20.6 percent in $F Y 1995$. The projects undertaken at the forrestal and Germantown facilities included the replacement on retrofit of light fixtures. windows, roofs, and various kinds of energy-consuming equipment; the installation of sensors that automatically turn off lights when they are not needed; changes in the operation and maintenance of energy consuming equipment; the installation of devices to monitor energy consumption; and the launching of a new energy-conservation awareness program. In addition, the Department increased its use of recycled paper far beyond the amount required by Execufive Order 72873.

Protection Agency and the Office of

Federal Procurement Policy, the

Challenge is a voluntary commitment

by Federal agencies to use the Federal

Government's buying power to create

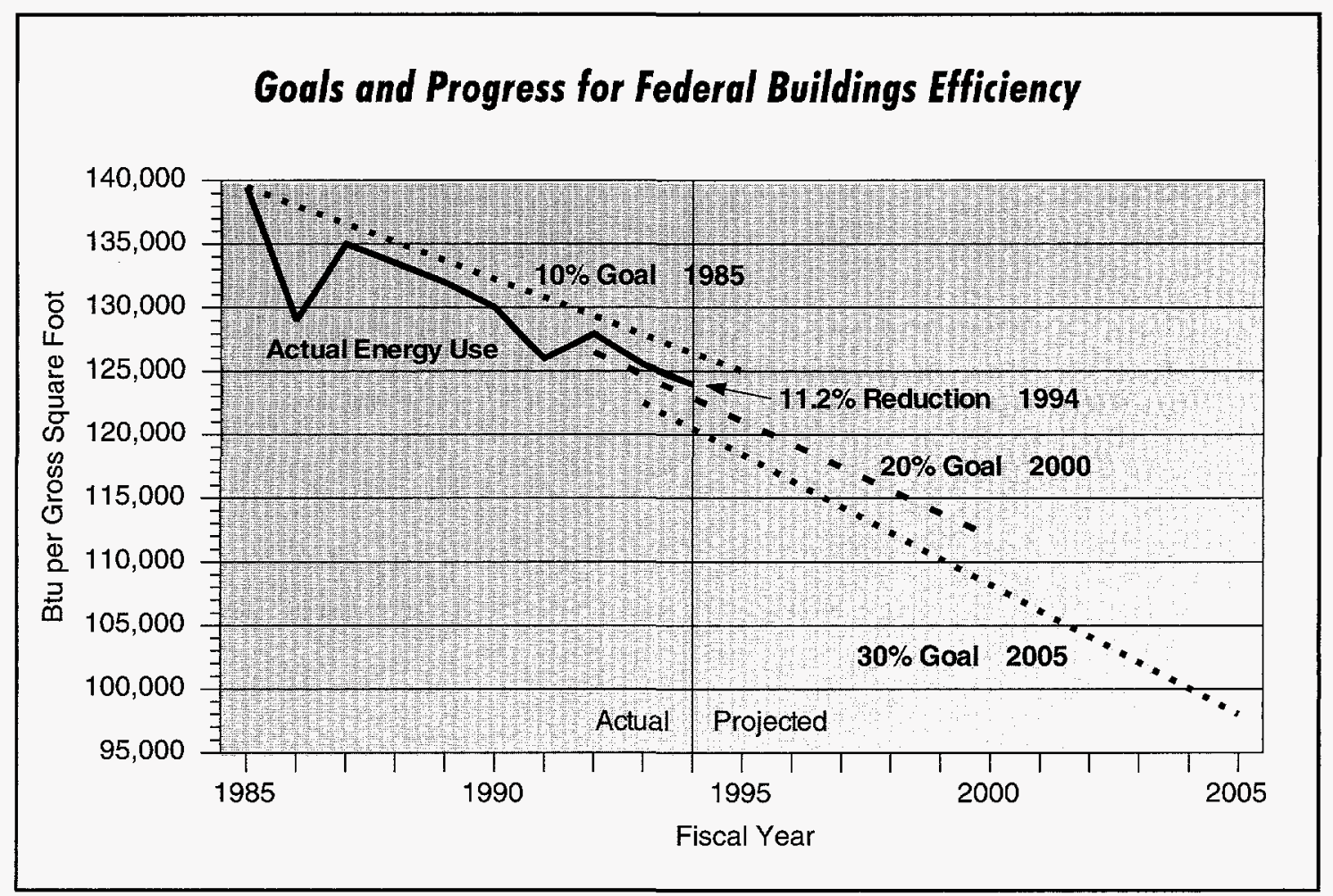




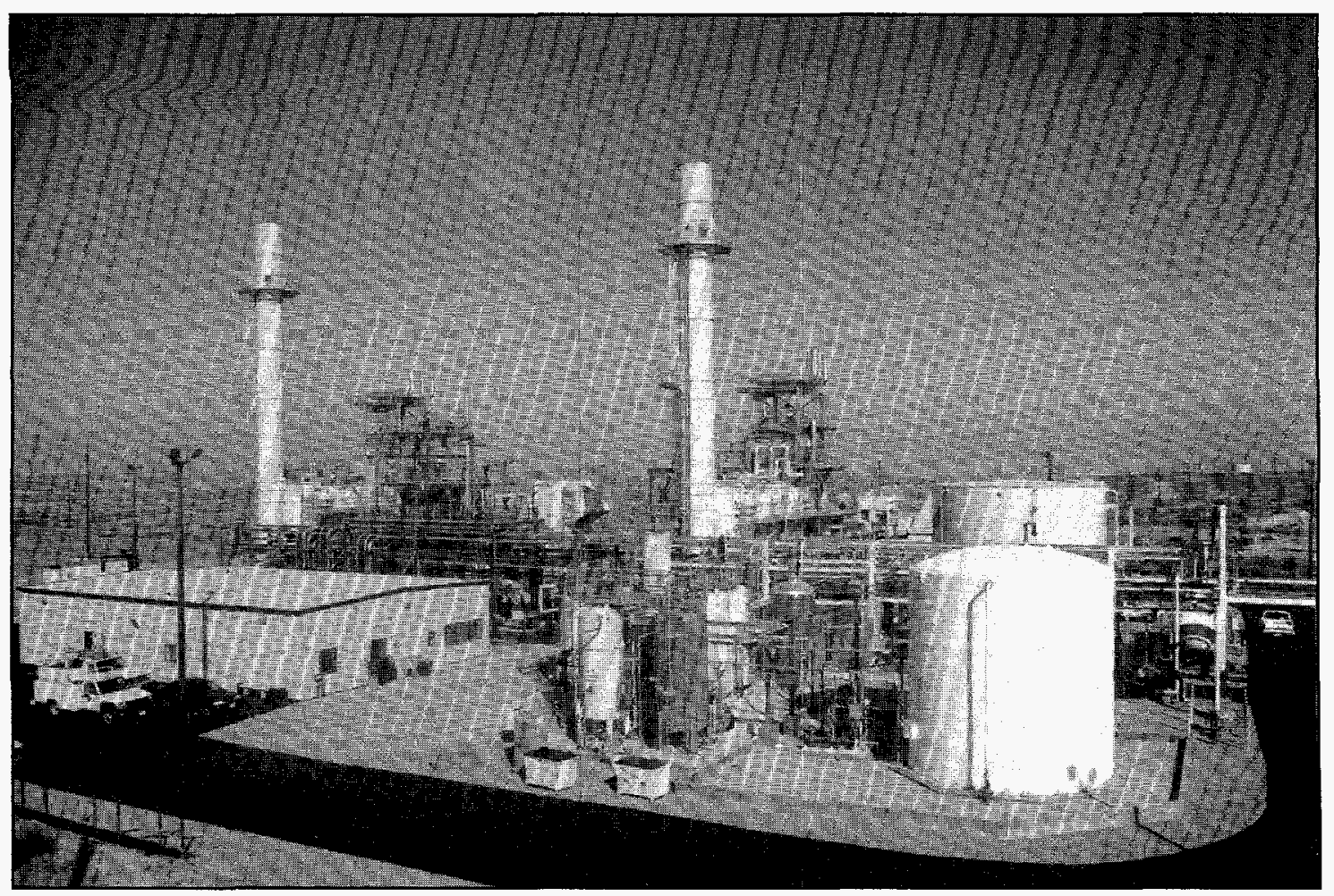

The Department of Energy's first cogeneration plant, completed at Elk Hills Naval Petroleum Reserve in California in November 1994, was one of 52 projects named nationwide as Federal Showcase Facilities for using technology to increase energy efficiency and reduce costs. Members of the Cogeneration Team also were selected for a 1995 Federal Energy Efficiency and Water Management Award. Elk Hills saves nearly $\$ 14$ million per year by generating its own electricity to power daily operations and earns another $\$ 2$ million annually by selling any excess electricity that is produced.

new entry markets for advanced energysaving technologies and products. The purpose of the Challenge is to help agencies meet the energy and water conservation goals of EPACT and Executive Order 12902, which direct agencies to buy products in the upper 25 percent of energy and water efficiency.

At the annual awards ceremony in October 1995, Federal Energy

Management Program Awards were presented to 67 winners from throughout the Federal Governmentemployees, small groups, and organizations - for their outstanding contributions in promoting energy efficiency, reducing energy costs, and creating a cleaner environment. The award winners achieved savings of approximately $\$ 130$ million in energy costs, saving the Federal Government approximately $\$ 3.8$ billion in accumulated energy costs over the last 10 years.

\section{The Domestic Nałural Gas and Oil Initiative}

The Administration announced the Domestic Natural Gas and Oil Initiative in December 1993. The initiative is an industry-driven effort designed to develop new and expanded opportunities for jobs in the domestic natural gas and oil industries, increase gas and oil production from domestic resources, and reduce U.S. reliance on foreign oil. Of the initiative's 49 proposed actions, one-third were 
completed by the end of 1995, and most of the remaining are scheduled for completion by the end of 1996 . These actions are expected to increase gas and oil production by an average of 450,000 barrels per day (oil- equivalent) during the 2001-2010 period.

In January 1995, the Department selected 31 proposals for funding under the Advanced Computational Technology Initiative Program. The program aims to accelerate analysis of oil and gas exploration and production potential by transferring national laboratory advances in computational technology to the private sector. For example, the Sandia National Laboratories have developed an algorithm, SALVO, that dramatically reduces the time needed to discover oil and gas in areas such as the Rocky Mountains and the Gulf of Mexico. The computer program rapidly processes exploratory sound waves sent into the earth. Because of thick salt sheets that refract sound at extreme angles, current algorithms take so long that the imaging of formations beneath the Gulf of Mexico is not feasible. A commercial version of SALVO is expected in early 1997.

We have been actively forming partnerships with States, other Federal agencies, industry, and others to simplify regulations that affect gas and oil supply without compromising environmental protection. The Department developed three common permit forms that four States and the Bureau of Land Management (BLM) agreed to use on Federal land; the new forms will reduce industry paperwork for these permits by 50 percent. We also identified seven areas of responsibility for downhole operations for which BLM will accept State approvals rather than duplicating the approval process, and we developed a memorandum of understanding between four States and BLM in which they agreed to a division of responsibilities to avoid duplication of effort-such as sending two inspectors to witness the same operation. As a result of the Department's analysis, BLM proposed a royalty reduction for heavy oil that could add more than 130 million barrels of oil reserves on Federal land in two States. During 1995, we also developed an oil and gas data management system to allow States and industry to save money by targeting their environmental management resources to areas of high environmental risk, and we created a State Computer Users Group to allow States to help one another implement the system with their own funds.

The Department added nine new joint government-industry oil field demonstration projects in 1995 to a nationwide program that is showing producers new ways to use technology to prolong the economic life of the Nation's most endangered oil fields. The selection brought to 33 the number of projects in the program. Industry is contributing more than $\$ 165$ million, more than matching the Federal Government's contribution of $\$ 125$ million. One of the program's earlier projects, the Lomax project in Utah, helped stimulate enough new activity in surrounding oil fields in 1995 to generate Federal royalties and taxes that will exceed the Government's investment in the entire field demonstration program. In Michigan, a government-university-industry project began demonstrating a horizontal drilling approach that produced 100 barrels per day from a field where conventional wells had typically produced less than 5 barrels per day. Overall, projects in this governmentindustry program have brought more than 50 million barrels of additional domestic oil into production, with the 
potential to add 3.5 billion barrels of new oil reserves from U.S. fields that otherwise were likely to be abandoned.

\section{Government-Industry Cooperation To Expand Natural Gas Production}

In 1995, the Department developed the Natural Gas Strategic and Multi-Year Plan in cooperation with industry and other government agencies. The aim of the plan is to focus all Departmental gas activities on the highest priority goals and objectives - and thereby help expand natural gas production and use to meet the Nation's environmental and energy-efficiency needs. We also began 27 cooperative, cofunded research and development projects with the Gas Research Institute. The projects focus on four key areas-drilling completion and stimulation, low-permeability

formations, resources and reserves, and gas processing - and they include significant individual projects, such as advanced slimhole drilling, natural fracture detection and optimization, Greater Green River Basin demonstration, secondary gas recovery, and gas processing.

\section{The Strategic Petroleum Reserve: Restoring and Extending lis Readiness}

The Strategic Petroleum Reserve was established to help reduce the economic and national security risks of oil supply disruptions. The Reserve currently stores more than 580 million barrels of crude oil in underground salt chambers.

During the past 2 years, the Department has been correcting problems that might have prevented some of the Reserve's oil from being withdrawn in the event of an energy emergency. An unusually high gas content in some of the oil, caused by the migration of gas from the surrounding salt, is being reduced by circulating the oil through surface degassing equipment. Heat exchangers have been installed to lower the temperature of oil that has been heated by natural geologic conditions. When these efforts are complete, the Reserve will be fully capable of meeting its 3.9-million-barrel-per-day drawdown capability, up from the 3.2-millionbarrel-per-day capability in 1995.

In 1995, the Department began preparing to decommission its Weeks Island, Louisiana, storage site because of geologic instabilities created by a naturally occurring fracture. During 1996, the site's oil inventory will be transferred to other Reserve storage locations in Louisiana and Texas.

\section{Electric Power From U.S. Agricultural Products}

Despite being hampered by funding cuts, the Department is making significant progress toward our goal of establishing the basis for an integrated biomass power industry that uses abundant "home grown" energy crops for renewable electricity generation. The aim is to develop five initial demonstration plants to validate highefficiency conversion technologies and energy-feedstock production. Three of these projects will be online in 1998, providing at least 40 megawatts to the electrical grid, stimulating an additional 200 megawatts of capacity through replication, and displacing 0.5 million tons of carbon emissions by the year 2000 .

Eight integrated biomass energy project case studies have been completed, and the final reports were issued in December 1995. Two advanced gasification/gas turbine technology, pilot-scale projects are under way. 
Cost-shared awards for integrated feedstock production and advanced conversion systems validation will be initiated in 1996. (These projects were to be initiated in September 1995, but were delayed because of fiscal year 1995 budget recisions.)

\section{The Next Generation of Nuclear Powerplants}

Approximately 22 percent of the electricity generated in the United States comes from nuclear powerplants. To preserve the nuclear option for future generations, the Department has been working to resolve issues that prevent continued operation of existing plants and has been participating with industry in the development of improved, standardized light-water reactors that will be simpler, safer, and less expensive to build and operate than current plants.

In July 1994, the Nuclear Regulatory Commission (NRC) gave final design approval to two evolutionary nuclear powerplant designs under joint development by the Department and the nuclear power industry: the Advanced Boiling Water Reactor and the System $80+$. This was a key step toward receiving NRC design certification, which is expected by the end of 1996 . Work is also proceeding on two passive plant designs. Final design approval for the first of these, the AP-600, is targeted for April 1997, with design certification following approximately 1 year later. The Department's technical work related to existing nuclear plants will help ensure the continued safety of the Nation's nuclear powerplants and will support the extension of powerplant life beyond the current arbitrary 40-year licensing period.

\section{Construction Begins on Advanced Clean Coal Powerplant in Florida}

The second of the major coal gasification demonstration powerplants in DOE's Clean Coal Technology Program moved off the drawing board in late 1994 and into field construction near Lakeland, Florida. Groundbreaking ceremonies on November 2,1994 , officially began construction of the $\$ 560$ million advanced power demonstration facility. DOE is providing $\$ 130$ million of the project cost (\$110 million for ope ations).

The 250-megawatt demonstration facility will be the centerpiece of Tampa Eledric Company's 1, 150 -megawall Polk Power Station. The plant will be built on the site of a mined-out phosphate mine in southwestern Polk County, Florida. A third of the 4,400-acre site will be converted to a habitat area consisting of wetlands, uplands, and a wildlife corridor. When it begins operating in fall 1996, the plant will be one of the Nation's cleanest and most efficient power facilities for generating electricity from coal. The advanced powerplant will clean more than 98 percent of the sulfur pollutants from coal while reducing nitrogen oxide emissions by more than 90 percent.



Secretary Hazel O'Leary tours Wabash River Coal Gasification plant during dedication ceremonies on November 8,1995 for the 262-megawatt clean, high-efficiency power project, one of the most important milestones in the Department of Energy's 10-year-old Clean Coal Technology Program. 


\section{Clean Coal Technologies}

Coal is projected to remain the Nation's dominant fuel for electric power generation well into the 21 st century. To ensure that the United States can continue to rely on its abundant domestic coal supplies, the

Department promotes the development of advanced technologies that can generate power from coal in an environmentally responsible, efficient, and affordable manner. The cost-shared Clean Coal Technology Program has brought many of these advanced concepts to the threshold of commercial acceptance, and the Department's coal research program is developing even more advanced technologies that will offer further environmental and economic benefits.

One of the Nation's largest Federalprivate energy and environmental initiatives, the Clean Coal Technology Program has evolved from an early focus on emission-control systems to an emphasis in later rounds on highly efficient, environmentally superior advanced power systems. Throughout the program, Federal funds have been leveraged nearly 2 to 1 by private and State financing. By the end of 1995, 19 of the 42 projects in the program had completed operations. Another 12 were either operating or in advanced stages of construction.

In 1995, the Nation for the first time began seeing major commercial dividends from its investment in clean coal technology. More than $\$ 9$ billion in domestic and international projects are benefiting directly from advances made in the Clean Coal Technology Program and associated research efforts. One major technological improvement, advanced low-nitrogen-oxide burners, has become a standard utility environmental compliance technology. Fully one-quarter of U.S. coal-fired capacity now uses this technology, accounting for nearly $\$ 1$ billion in commercial sales.

Late in 1995, the program achieved another major milestone when the pioneering Wabash River Project in Indiana completed construction and generated its first electricity. The 262-megawatt plant is the largest of its type in the world to use integrated gasification combined-cycle technology, a new electric power generating option being readied for the 21 st century. Rather than burning coal directly, the gasification combined-cycle technology allows the facility to first gasify it, and then burn the gases in a combustion turbine. Heat from the process is also used to create steam for a conventional steam turbine cycle. This new technology effectively doubles the output of the old steam generator while reducing sulfur and nitrogen oxide pollutants by 98 percent and 90 percent, respectively. 


\section{SCIENCE AND TECHNOLOGY PROVIDING THE KNOWLEDGE THAT DRIVES THE NATION'S FUTURE}

Science and technology provide the foundation underlying all current Departmental missions and activities and the springboard for ensuring a clean, safe, and prosperous future.

The Administration's commitment to a sustainable energy future is reflected in our emphasis on research and development (R\&D) of technologies that advance energy productivity and protect the environment. Our programs to develop advanced materials and manufacturing processes are part of that effort. The Department also funds research aimed at mapping the human genome by 2005 , developing advanced medical technologies and pharmaceuticals, and determining the structure and function of living cells and molecules. In addition, we are working to develop and understand the data needed to predict if and how energy can affect climates.

Our vision is to have world-class scientists and engineers, working in world-class facilities on leading-edge problems, spawn the knowledge that revolutionizes technology that others need to achieve their visions.

\section{Scientific Excellence, Technological Leadership}

The Department's science and technology infrastructure and continued sponsorship of precompetitive research maintain U.S. technological leadership and sustain the Nation's scientific excellence. Over the past 50 years, the Department and its predecessor agencies have established an extensive national laboratory and university network of expertise in science and engineering. This network consists of 9 major multiprogram laboratories, 10 single-purpose laboratories, 11 smaller special-mission laboratories, and a wide range of special user facilities that the private sector simply cannot afford to provide. The scientific and technical talent at these laboratories is extraordinary. In 1994, the Department's funding for $R \& D$ was $\$ 7$ billion, which is the fourth largest for a Federal agency and represents nearly

\section{Nobel Prize Winners and DOE Research}

The Department of Energy and its predecessor agencies funded the research of four of the five scientists awarded the Nobel Prize in 1995 for their work in physics and chemistry Mario Molina of the Massachusetts Insfitute of Technology and $F$. Sherwood Roland of the University of California at Irvine were recognized as codiscoverers in 1974 of the connection between chlorofluorocarbons (CFCs) and ozone depletion.

Martin Perl of the Department's Stanford Linear Accelerator Center discovered the tau lepton subatomic particle in 1976. He shared the physics prize with Frederick Reines, who was employed at Los Alamos National Laboratory when he discovered the neutrino particle using a reactor at the Savannah River Site. 


\section{The Department's network of laboratories and user facilities form the backbone of the Nation's scientific and technical infrastructure}

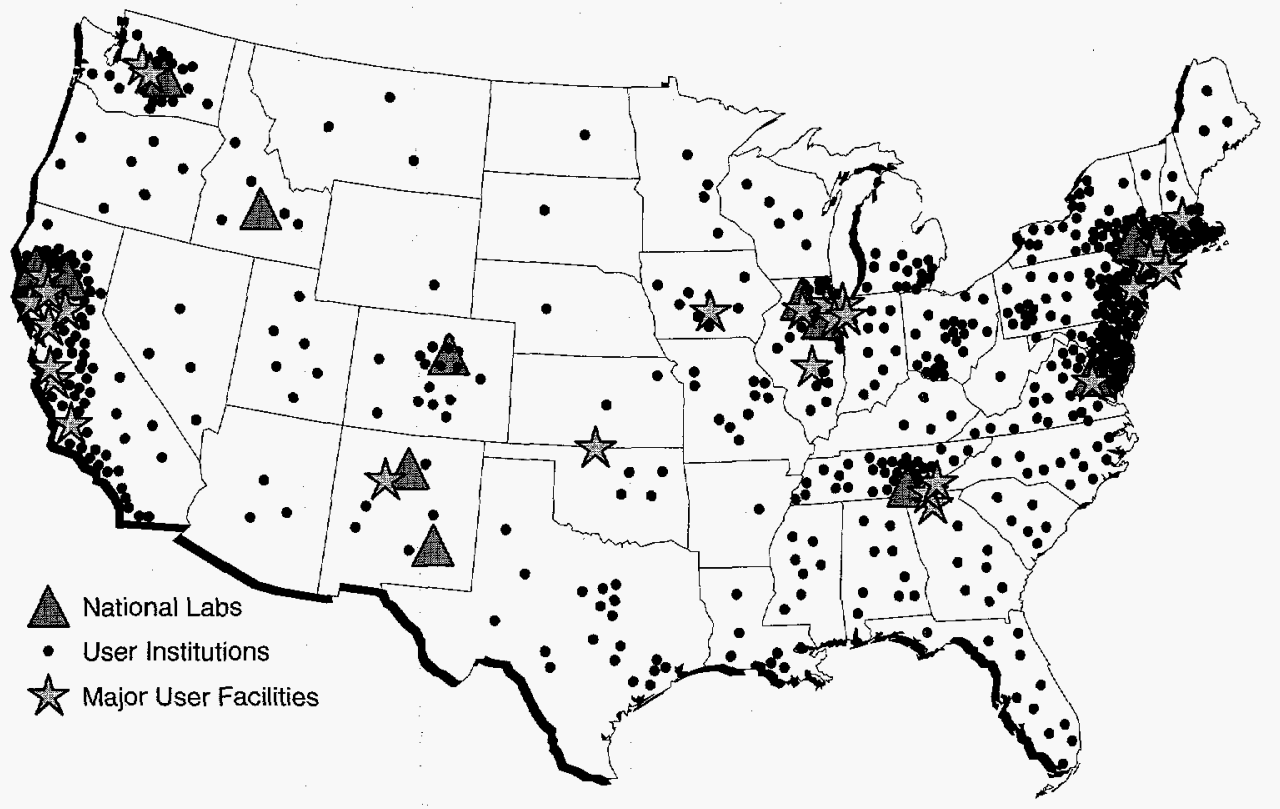

10 percent of total Federal spending on R\&D.

Our research extends to materials sciences, chemical sciences, engineering and geosciences, energy biosciences, applied mathematical sciences, high energy and nuclear physics, fusion energy, and the biological and environmental sciences. Our Office of Energy Research programs continue to contribute the fundamental science necessary to understand and predict the consequences of energy production and use, as well as understand the fundamental nature of matter.

The importance of continuing Federal R\&D efforts was emphasized in Energy RED: Shaping our Nation's Future in a Competitive World, the final report of the Task Force on Strategic Energy Research and Development. The report was the product of a 9-month study, undertaken at the request of Secretary O'Leary, by a 30 -member task force of leading experts from industry, academia, and research under the chairmanship of Daniel Yergin, president of Cambridge Energy Research Associates. The June 1995 task force report described Federal R\&D efforts as "essential to our Nation's future well-being" and said that they contribute to the Nation's economic growth, security, environmental quality, and competitiveness in the international marketplace. Declaring that "research and development is our Nation's investment in its own future" and that "America's science and technology base may well stand as our most important renewable resource," the report found that, nonetheless, the Department's energy $R \& D$ funding had been reduced in constant dollars by 75 percent over the past 17 years.

The task force warned that widespread cutbacks in Federal and private-sector $R \& D$ may portend an $R \& D$ crisis. Private-sector energy $R \& D$ is being scaled back and is shifting away from 


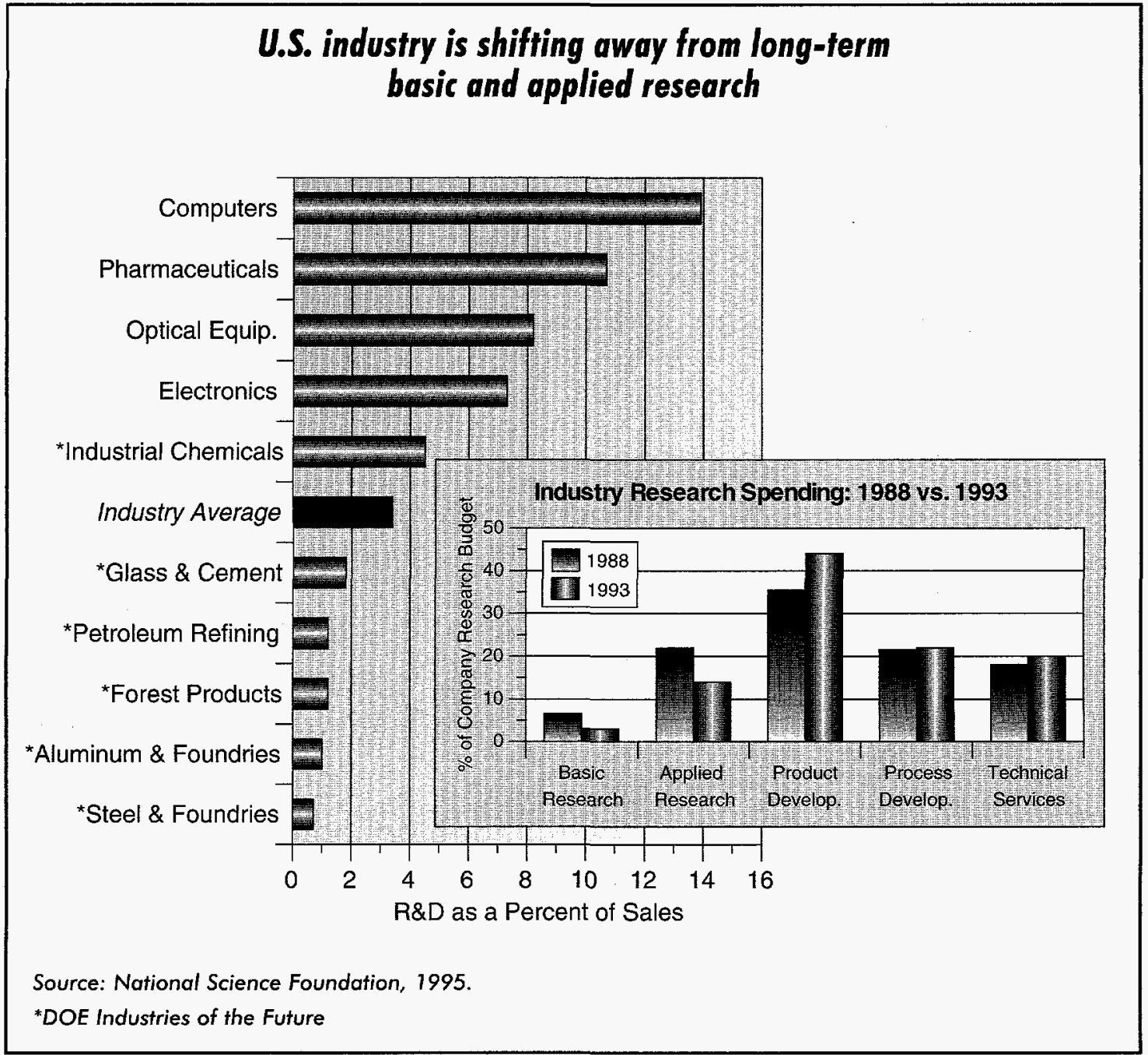

research with long-term and midterm goals. Despite potential benefits to their competitiveness in the long term, U.S. businesses are increasingly reluctant to undertake energy research in the public interest where profits are unlikely to be realized in the short term.

\section{Investigating the Causes of Global Climate Change}

The Department played a major role during the past 2 years in advancing fundamental knowledge of the natural and human causes of climate change, including geologic and atmospheric processes that affect such change. For example, the Department completed the highest resolution ocean general circulation model and delivered it to the climate and ocean modeling communities. We also completed the first Atmospheric Model Intercomparison Experiment, which identified where models need improvement and explained the reasons model results differ. Through the National Science and Technology Council, in cooperation with other Federal agencies, we funded new research on the effects of climatic and atmospheric changes on terrestrial ecological systems. 


\section{Department of Energy Labs Map Human Chromosomes}

Two of the Department of Energy's Human Genome Research Centers published detailed maps of two complete chromosomes in 1995. These are the most detailed maps yet of the locations of human genes. These maps are the result of 5 years of research thus far in the international effort to identify all DNA found in humans.

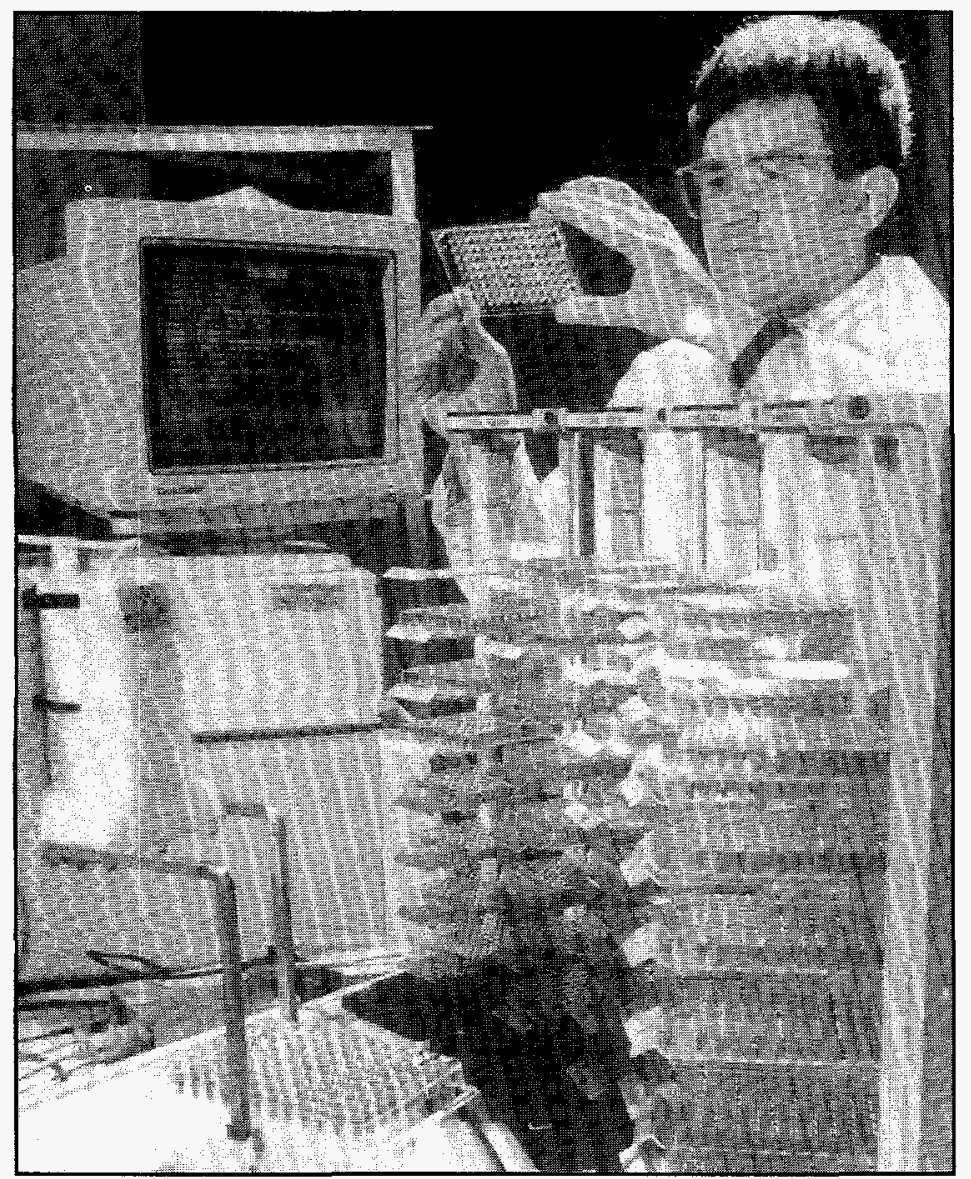

In 1994, HYSEQ, Inc. of Sunnyvale, California, a leader in gene sequencing was granted patent rights to a biochemical "super chip" developed at ANL that can decipher the human genome faster than before. Gene sequencing enables scientists to study a gene's function, develop treatments for bith defects, genetic diseases, and tools for early detection of cancer. This technology transfer promises to have farreaching medical impact.

\section{Isotopes for Health Care}

Molybdenum-99 is an extremely important isotope for cancer diagnosis; in the United States alone, more than 15 million diagnostic medical tests per year rely on this isotope. Although the U.S. medical community uses about 60 percent of the worldwide supply, no private-sector production of this vital isotope has occurred in the United States since 1989. The entire North American supply comes from a single aging reactor in Canada. The nuclear medicine community has requested that the Department help ensure a stable backup source of this important material until reliable alternative sources become available.

To ensure sufficient U.S. supply in the interim, the Department has been working on the environmental evaluation for establishing a domestic source of this isotope. On October 1, 1994, the Department began formal planning and the National Environmental Policy Act (NEPA) evaluation. Once the NEPA process is complete, and depending on the options finally selected, domestic production of molybdenum-99 could begin in 1997. When Canadian, U.S., or other suppliers establish new reliable sources, the Department will terminate support for this backup production.

\section{Peaceful Uses of the Atom: Proceeding With Caution}

Although four cooperative agreements under the U.S.-Russian Federation Peaceful Uses of Atomic Energy Agreement are proceeding satisfactorily, a new umbrella agreement was not signed in 1995 because of a decision reached by the Department of Energy, the State Department, the National Security Council, and the Office of the 
Vice President that the United States should not proceed with the agreement so long as Russia intends to move forward with a contract to provide nuclear reactors to Iran. The U.S. Government is concerned that Iran will use Russian technology to develop a nuclear weapons program. Extension of the agreement would allow at least temporary continuation of cooperative efforts begun in 1973 for energy research, reactor safety, environmental restoration, and nuclear waste disposition.

\section{Commitment to Service and Performance at Our Science Facilities}

The Department's world-class user facilities form the backbone of the Nation's scientific and technical infrastructure. In the field of high energy physics, our facilities at Fermi National Accelerator Laboratory, Stanford Linear Accelerator Center, and Brookhaven National Laboratory provide scientists with the means to conduct experimental research on subatomic particles. The Tevatron accelerator at Fermilab continues to set world records for particle beam intensity by greatly exceeding its original 1981 design luminosity. At the Stanford Linear Accelerator Center, scientists recently achieved the world's most precise measurement of the weak mixing angle, a fundamental parameter of the Standard Model.

In nuclear physics, the research forefront is focused on incorporating the quark substructure of the nucleon into the understanding of nuclear structure. The Thomas Jefferson National Accelerator Facility became operational in 1995 and construction of the Relativistic Heavy Ion Collider (RHIC) remains on cost and schedule for completion in 1999. Completion of the Radioactive Ion Beam Facility (RIB) at

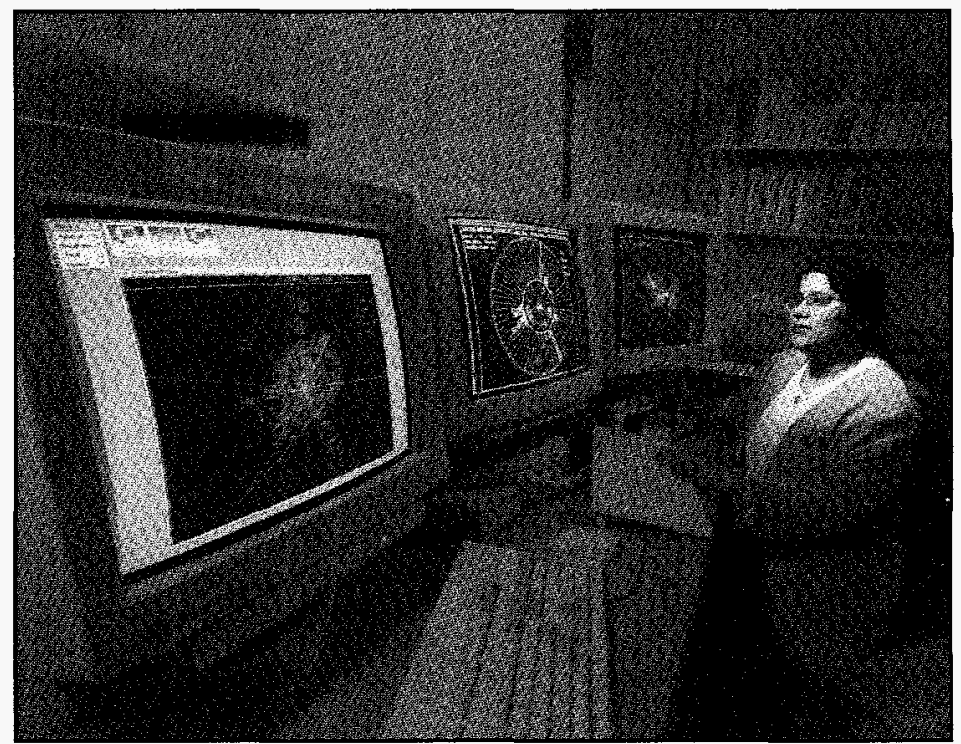

Dr. Meenakshi Narain examines possible top quark events at Fermilab's DZero experiment.

Oak Ridge National Laboratory will allow for experiments in nuclear astrophysics and unstable nuclei.

The Department is committed to improving the efficiency of the operations of our basic research facilities and the quality of their services to scientists. The Secretary of Energy

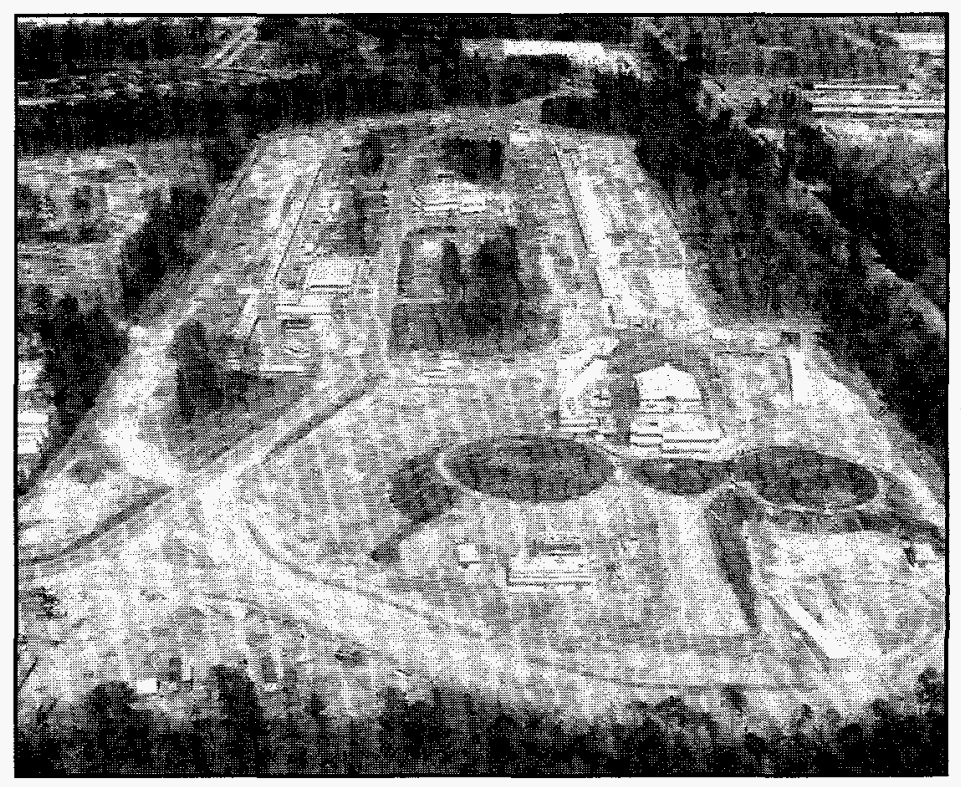

An aerial view of the Thomas Jefferson National Accelerator Facility site shows the two parallel straightways of buildings that hold the power supply to the linear accelerator buried 25 feet directly below them. 
Advisory Board Task Force on Alternative Futures for the Department's National laboratories, chaired by Robert Galvin, chairman of the executive committee of Motorola, Inc., completed its report in February 1995. The report concluded that the "laboratories' research role is part of an essential, fundamental cornerstone for continuing leadership by the United States" and recommended "bold alternative" means of governance for the laboratories.

\section{The Department set out an} implementation plan to respond to the Task Force's recommendations. Deputy Secretary Charles Curtis testified in September 1995 that the goals of this "Management Improvement Roadmap" are to-

- Create a more productive, missionfocused, and cost-effective Department and laboratory system

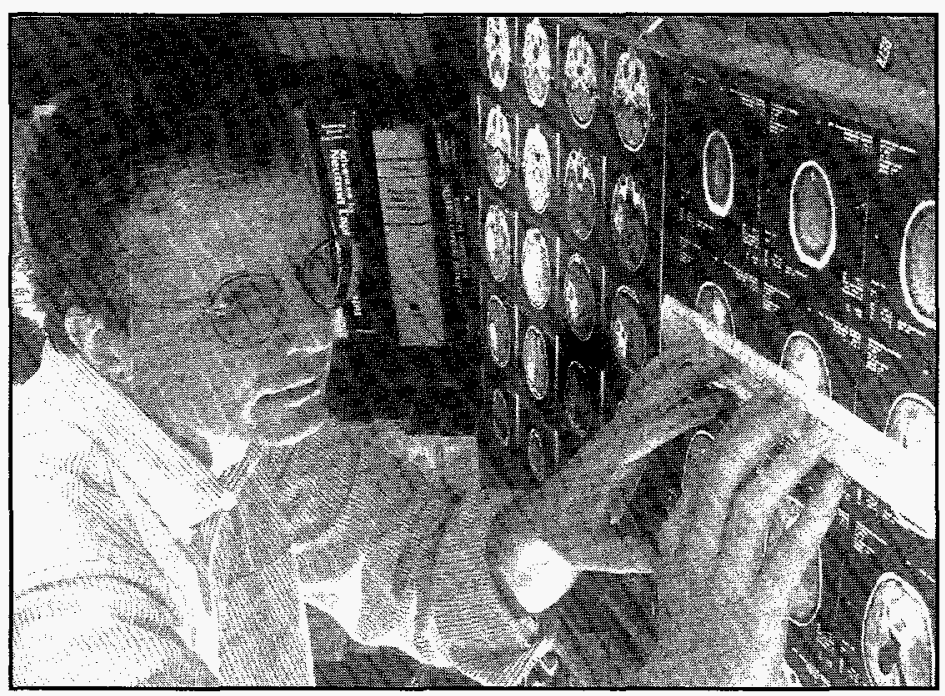

Brookhaven National Laboratory's Dr. Jeffrey Coderre, a leading Boron Neutron Capture Therapy researcher, examines brain scans from patients with glioblastoma multiforme, an especially deadly brain tumor. These patients, often given less than 9 months to live, may benefit from the experimental treatment being performed only at Brookhaven and MIT under strict FDA guidelines. Fiffeen patients were treated at Brookhaven in a 1995 clinical trial, and more patients are now being treated with higher radiation doses in the program's second experimental phase.
- Adopt best business practices throughout the system

- Require performance-based, resultsoriented contractor accountability

- Work aggressively to achieve credible external regulation and oversight

- Shift the focus at the laboratories away from process compliance and toward mission success and results

The Galvin report and the Department's response were considered in an Administration review of Federal laboratories, the results of which were released in September 1995. The President concluded that "these laboratories provide essential services to the Nation." To ensure that the laboratories' resources will be used in the most efficient and effective manner possible, the President announced reforms to do away with excessive management, clarify missions, and coordinate and integrate laboratory resources. The President also signed a directive affirming that "the continued vitality of all three of the Department's nuclear weapons labs will be essential" for the purpose of ensuring "confidence in the safety and reliability of the nuclear weapons stockpile in the absence of nuclear testing."

During 1995, we increased operational efficiency throughout the Department's laboratory system. For example, the percentage of available operating time delivered to users was 90 percent or better at the synchrotron radiation facilities. The Advanced Light Source increased the number of users by 80 percent; the High Flux Beam Reactor increased neutrons provided to users by 50 percent; and our nuclear physics accelerators delivered 5 percent more beam hours, and utilization increased from 40 to 67 percent.

Technical performance of the accelerator facilities also improved in 1995. Beams 
at all operating synchrotron facilities were made at least 3 times more stable, and Advanced Light Source beamlines increased by 50 percent. The neutron beam at the Brookhaven Medical Research Reactor was optimized for Boron Neutron Capture Therapy Phase I/II trials, and 10 patients were treated there through the end of September.

In 1995, we also made significant advances in the termination activities associated with the Experimental Breeder Reactor-II (EBR-II) and the Fast Flux Test Facility (FFTF). The EBR-II and the FFTF are sodium-cooled liquidmetal reactors that were used extensively for fuels and materials testing. When missions ceased for these reactors, our goal was to shut them down to an industrially and radiologically safe condition. All of the fuel has been removed from the FFTF, and defueling operations have begun for the EBR-II. The EBR-II activities should be complete in 1998; the FFTF activities should be complete in 2001 .

\section{High-Performance Computing: Advancing the State of the Art}

The Department is using its supercomputing and computational science capabilities to advance the state of the art in high-performance computing and to support the Department's missions.

To meet the computing needs of scientific researchers, the Department conducted a competitive procurement at the National Energy Research Supercomputer Center for the next generation production super-computer. We also deployed advanced network services to major sites on the Department's nationwide high-speed

\section{Our high-speed Energy Science Network links the Department's labs to each other and to scientific facilities worldwide}

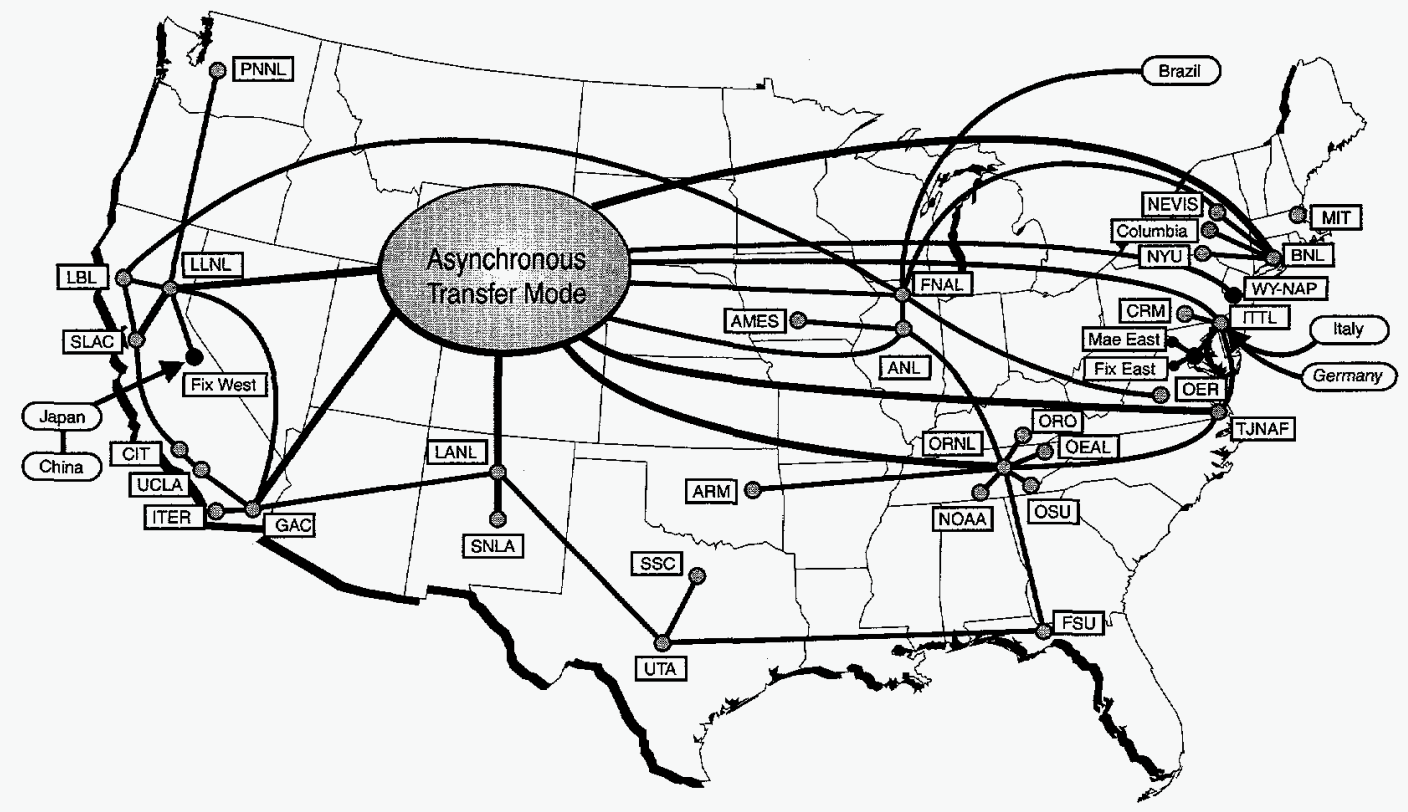


computer network, the Energy Science Network (ESnet), via a competitively awarded contract with U.S. Sprint that will allow a tenfold increase in available bandwidth between sites. Sprint is demonstrating a new communications technology known as Asynchronous Transfer Mode (ATM) on the Department's network. Sprint is investing $\$ 500$ million in the technology, and the contract has helped speed up the industry timetable for introducing ATM into commercial operation by 2 years.

We have also made progress in highperformance computing applications. Through publications and a joint workshop with the Electric Power Research Institute and the National Economic Council, the Department has helped define the critical policy and technical issues for high-performance computing applications in energy supply and demand management. We also began two new research activities to develop energy- and power-quality monitoring equipment that can be used via the Internet to monitor and control multiple buildings, as well as four new collaborative laboratory-industry computational research projects that will improve oil and gas recovery under the Advanced Computational Technology Initiative program.

\section{Science on the "Information Superhighway"}

The Department is using the

"information superhighway" to make its scientific and technical information readily available. We are upgrading connections to the Internet from many of the Department's advanced research sites to allow remote access by approved researchers at universities, industries, and government agencies. The joint Energy Research and Defense
Programs DOE 2000 Initiative is deploying advanced communications and high-performance computing that will transform the national laboratories. As "National Collaboratories," the Department's research facilities will allow scientists nationwide to network to solve problems as easily as if they were in the same building.

Moreover, through the Internet and other communications systems, we are increasing access to the Department's scientific and technical information for all our customers. In 1994, 178,000 of our customers accessed the Department's scientific information. From October 1, 1994, through June 30, 1995 , this number more than doubled. The 363,500 customers served in those 9 months exceeded the original goal of 231,000 customers served in all of 1995 by 57 percent.

\section{Educating the Next Generation of Scientists}

The Department supports the Administration's Goals 2000 objective of recapturing U.S. preeminence in science and math education. From October 1, 1994, though June 30, 1995, the Department provided new instructional tools to more than 100,000 teachers in urban and rural school districts across the United States. This surpassed our goal for the entire fiscal year by 50 percent. Also during 1995, the Department entered into agreements with the National Science Foundation and the Department of Education to encourage collaboration by Federal agencies to provide new instructional tools to teachers. In addition, teachers and students (and anybody else) can now access new instructional materials and tools via the Department of Energy's Home Page. 
In 1995, more than 2,480 students and faculty from more than 400 U.S. colleges and universities participated in the Department's Laboratory Cooperative Program. The program provides participants with access to our unique facilities and technical expertise generally not available on academic campuses. Also during the year, 420 undergraduates were selected by scientists at seven of the national laboratories to participate in academic term research appointments at the labs. In the summer of 1995, the Department issued University Reactor Sharing Grants totaling $\$ 600,000$ to enable 28 universities to share their research reactors with high schools, colleges, and universities that do not have comparable research facilities. We have also been working with U.S. electric utilities to provide matching aid to university nuclear engineering programs. Matching grants totaling $\$ 800,000$ were issued to 17 universities during the summer of 1995 . These programs help ensure the adequate future availability of nuclear professionals in fields related to nuclear science and technology.

Also in 1995, the Department awarded $\$ 5.3$ million in University Coal Research grants to 25 student-teacher research teams to conduct fundamental studies of the science of coal and how coal affects the world environment. This program, in its 16 th year, has funded more than 470 research projects and helped train a new generation of scientists and engineers. Later in the summer, the Department selected seven natural gas, oil, and coal research projects to be carried out by studentteacher teams at historically black colleges and universities (HBCUs).

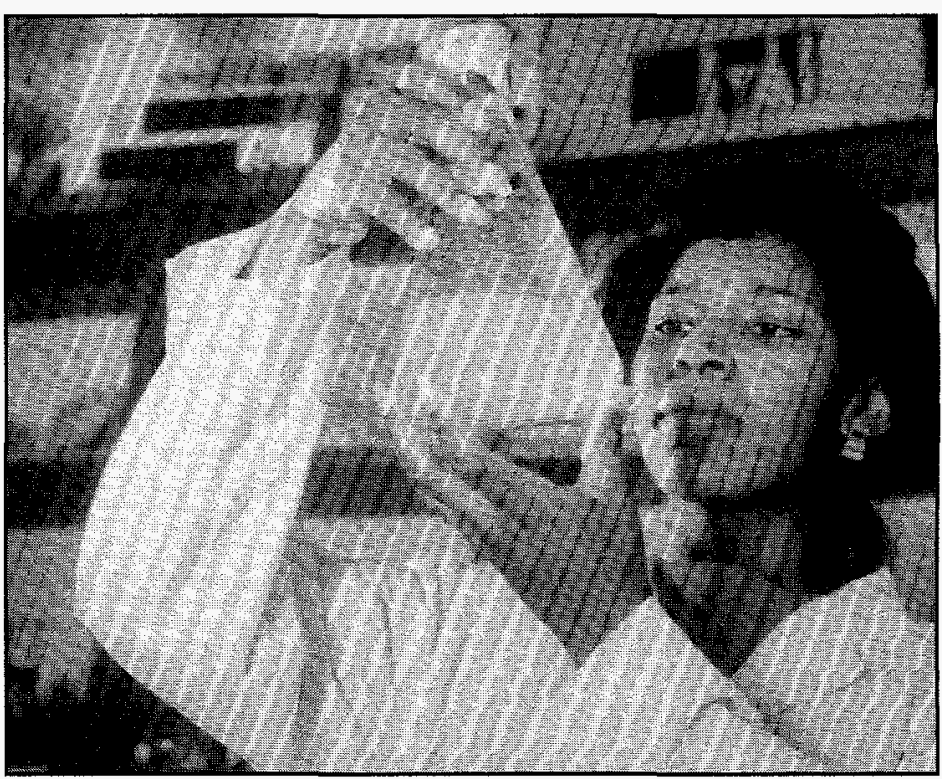

Through our national laboratories, the Department collaborates with historically black colleges and universities to promote research and education. Laboratory support takes the form of assistance in research collaborations with faculty and students, equipment loans, and consulting for development or enhancement of curricula and degree programs.

\section{Diversifying America's Science Workforce}

A strong U.S. economy relies on the full use of the talents and capabilities of our Nation's diverse workforce. Recognizing that the Department plays an important role in diversifying and developing an effective technical workforce to meet the critical technology needs of our Nation, the Department has established partnerships with HBCUs and other minority institutions in promoting academic excellence and strengthening and expanding their capacity to conduct $R \& D$. We support HBCUs to improve institutional infrastructure, support scientific research, and provide equipment as part of the overall support for minority students, engineers, and educational institutions. In 1995, the Department provided slightly more than $\$ 50$ million to these colleges and universities. 


\section{NATIONAL SECURITY REDUCING THE GLOBAL NUCLEAR DANGER}

Reducing the global nuclear danger is one of the primary goals of the U.S. national security strategy. Nuclear deterrence, an essential part of the U.S. investment in national security, has paid extraordinary dividends over the last 45 years. Because of the nuclear dangers we continue to face, it is an investment the United States cannot afford to neglect. As the President has stated, "We will retain strategic nuclear forces sufficient to deter any future hostile foreign leadership with access to strategic nuclear forces from acting against our vital interests and to convince it that seeking a nuclear advantage would be futile. Therefore, we will continue to maintain nuclear forces of sufficient size and capability to hold at risk a broad range of assets valued by such political and military leaders."

The Department's contributions to national security include maintaining a safe, secure, and reliable nuclear weapon stockpile; dismantling excess weapons; and making and implementing decisions regarding the long-term storage and disposition of surplus fissile materials that could be used in weapons.

The Department also plays a pivotal role in the areas of nonproliferation and nuclear threat reduction. The Department's unique capabilities in these areas can be seen in the wide array of ongoing activities and initiatives designed to reduce the threat of nuclear proliferation. The Department provides major policy and technical support of the U.S. Government's foreign policy and national security objectives in the areas of arms control and nonproliferation, and to the international arms control and nonproliferation community as a whole.

\section{A Safe, Secure, and Reliable Nuclear Weapon Stockpile}

In 1994 and 1995, the U.S. nuclear weapon stockpile underwent dramatic changes as this Nation took steps to reduce the global nuclear danger. Thanks to unprecedented arms control agreements between the United States and the former Soviet Union, nuclear forces continue to be dramatically reduced. Full implementation of the START I and START II protocols, assuming Russian ratification or compliance, is projected to result by 2003 in a 79-percent reduction in the total active stockpile from the 1988 level. The United States has halted the development and production of new nuclear weapons and closed portions of the weapon complex no longer needed to support the significantly smaller, less diverse stockpile of the future. But the United States still must ensure the 


\section{We've changed the focus of our nuclear deterrence activities}

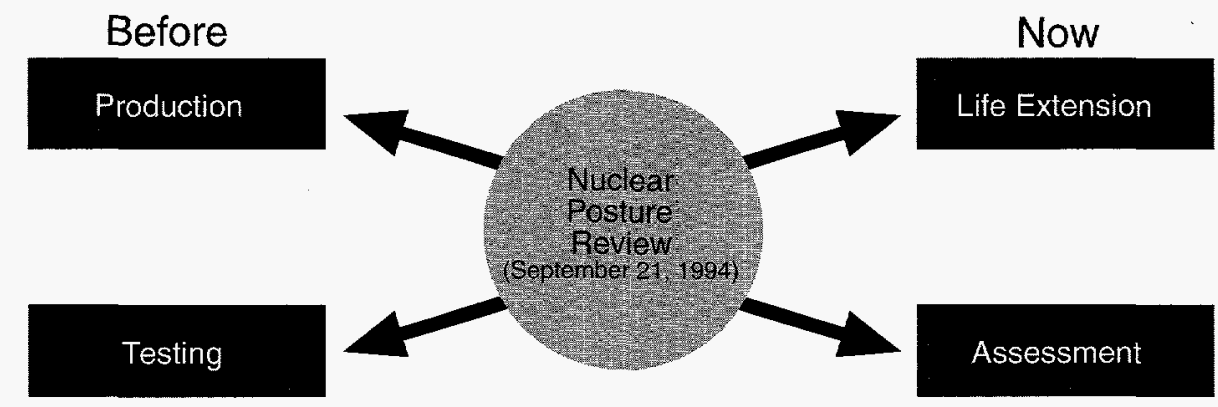

safety, security, and reliability of the enduring nuclear weapon stockpile. Even in a world of fewer nuclear weapons, the task before the Department of Energy, its laboratories, and plants is extraordinarily challenging.

In the past, confidence in the stockpile was ensured through weapon research and development (R\&D) in the national laboratories, the production of new weapons, and underground nuclear testing. However, no U.S. underground nuclear tests have been conducted since October 1992. In July 1993, the President announced a continuation of a moratorium on underground nuclear testing that was extended until September 1996. The President challenged the Department "to explore other means of maintaining our confidence in the safety, reliability and performance of our own weapons." The President directed that "this include stockpile surveillance; experimental research, development, and engineering programs; and the maintenance of a production capability to support these efforts." This challenge was codified when Congress passed the 1994 National Defense Authorization Act, which directed the Secretary of Energy "to establish a stewardship program to ensure the preservation of the core intellectual and technical competencies of the United States in nuclear weapons." It was also substantiated in the Department of Defense's Nuclear Posture Review completed in September 1994.

The President reemphasized the importance of the Stockpile Stewardship and Management program when he announced on August 11, 1995, that the United States would seek a "zero yield" Comprehensive Test Ban Treaty. The President's decision was based in part on assurances from the Secretary that an adequately funded Stockpile

Stewardship and Management program, along with a series of additional safeguards, would ensure the continued safety and reliability of the nuclear weapon stockpile.

The Department developed the Stockpile Stewardship and Management program as a single, highly integrated technical program with three objectives:

- To support the enduring nuclear weapon stockpile with safe, secure, and reliable nuclear weapons, while transforming the weapon complex 
into one that is smaller and more cost-efficient.

- To preserve the core intellectual and technical competencies of the weapon laboratories. Without underground nuclear testing, confidence in the U.S. nuclear deterrent will rest with our confidence in the competency of the people who must make the scientific and technical judgments related to the safety and reliability of U.S. nuclear weapons using new computational approaches.

- To ensure that the activities needed to maintain the Nation's nuclear deterrent are coordinated and compatible with the Nation's arms control and nonproliferation objectives.

During 1994 and 1995, the Department took a number of important actions in establishing this program.

Key to ensuring the reliability of the stockpile is having an assured tritium production source. Tritium is a vital component of every weapon in the stockpile; and with a short radioactive half-life of 12.3 years, it must be replenished periodically. If the tritium is not replaced, the weapons will not perform as designed. In 1995, the Department completed work on the Tritium Supply and Recycle Programmatic Environmental Impact Statement and associated studies.

Understanding and controlling fusion in the laboratory setting will greatly enhance our studies of the physics of nuclear weapons by verifying predictions of extremely complex computer models. In October 1994, the Secretary announced that the Department would proceed with the engineering and design of the National Ignition Facility (NIF) and that the preferred site was the Lawrence
Livermore National Laboratory. Planned to be the world's largest and most powerful laser, NIF will help us improve our ability to evaluate problems in secondary components, make the necessary repairs or modifications, and subsequently evaluate and recertify those nuclear components. The Secretary also directed that a careful review of NIF's impact on U.S. nonproliferation goals be undertaken by the Office of Nonproliferation and National Security.

Numerical simulation and computer modeling will be the principal means of recertifying the safety and performance of primary and secondary components and predicting full system behavior. On September 7, 1995, the Department announced a \$45-million joint development contract between the Department, Sandia National Laboratories, and the Intel Corp. to build the world's most powerful computer by the end of 1996 . This project, part of the Accelerated Strategic Computing Initiative, will produce a computer 10 times more powerful than any existing machine. It is a first step toward achieving the advanced computational capability needed to address national security needs in an era without underground testing.

\section{Continued Headway in Dismantling Warheads}

To reduce the nuclear danger and enhance international accord, the Department places primary importance on safely dismantling nuclear warheads. We are delivering on our commitments by publicly announcing our dismantling plans and results. In 1995, we safely dismantled 1,393 nuclear warheads. This included completely dismantling the B57, W68, and W71 warheads. 


\section{Leadership in Arms Control and Nonproliferation}

Nonproliferation of nuclear weapons is one of the Nation's highest priorities, and the Department is the preeminent U.S. agency for providing technical and analytical support in the areas of arms control, nonproliferation, and nuclear threat reduction. During 1994 and 1995, we focused our efforts on the following:

- Securing nuclear materials and expertise in Russia and the newly independent states

- Limiting weapons-usable fissile material worldwide

- Establishing transparent and irreversible nuclear reductions

- Strengthening the nuclear nonproliferation regime

- Controlling nuclear exports

One of the most significant accomplishments in this area was the transport in November 1994 of nearly 600 kilograms of weapon-grade highly enriched uranium (HEU) from Kazakhstan, where it was judged to be insufficiently secure, to the United States for interim storage pending conversion to low-enriched uranium suitable for use as reactor fuel. The then-secret operation, code-named "Sapphire," included an 8-week repackaging operation performed by U.S. Department of Energy experts in Kazakhstan who prepared the HEU for international shipment and storage at the Department's facility at Oak Ridge. In July 1995, the Department began shipment of Sapphire HEU to a commercial vendor where it was placed under International Atomic Energy Agency (IAEA) safeguards before being downblended for use as power-reactor fuel. More generally, the program to secure nuclear materials and expertise in Russia and the newly independent states has expanded rapidly. In 1995, we achieved material protection, controls, and accounting upgrades for more than 8 tons of plutonium and HEU at 26 facilities in those countries.

\section{Leading Worldwide Control of Weapon Materials}

To make the world a safer place, the Department has taken a leading role in the effort to control weapon materials in other countries. Our commitment to reducing the threat posed by the former Soviet Union's nuclear materials led the Department to undertake measures to secure those materials and to share appropriate expertise in nuclear material control and accounting. This same commitment motivated the Department to make transparent and irreversible reductions in nuclear weapon inventories and to seek the same from the Russian Federation. The Department's campaign to reduce the world's stockpiles of plutonium and HEU, and their civil use, met with great success.

The Department developed a comprehensive program to implement the June 23, 1994, Gore-Chernomyrdin

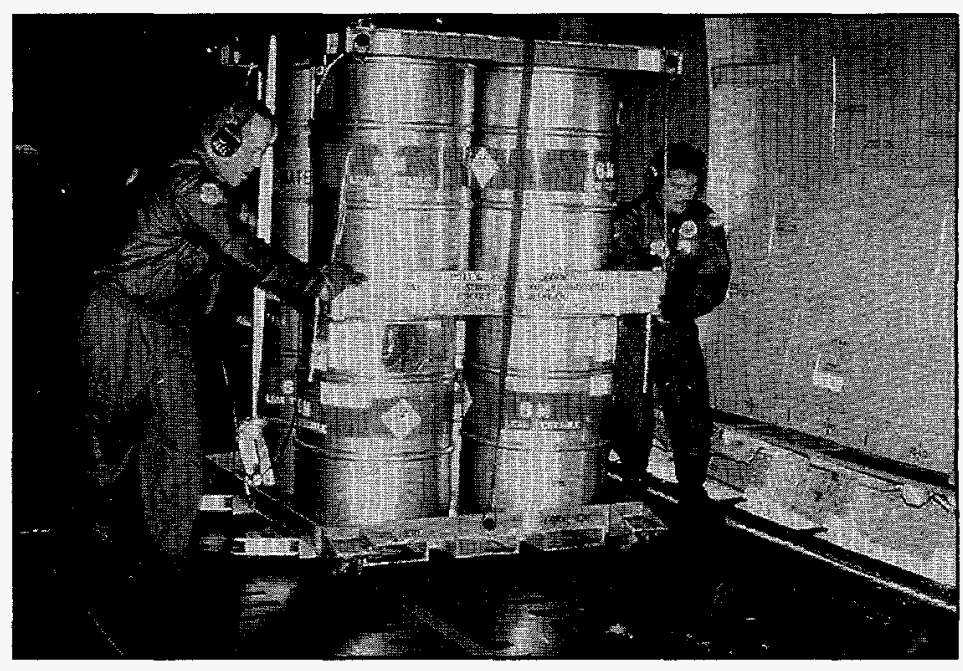

Loading materials from Kazakhstan onto U.S. Air Force Cargo aircraft during Project Sapphire. 
agreement to end the production of weapon-grade plutonium at three remaining production reactors in Russia. This program was outlined in a supplemental agreement signed on June 30, 1995, and included studies to examine the possibilities of replacing the reactors with fossil-fuel plants or replacing them with new nuclear plants and converting the cores so they could produce power but not weapon-grade plutonium. (The results of the studies subsequently focused efforts on the core-conversion option.)

Agreement has also been reached with the Russian Federation on a technical means of carrying out reciprocal inspections at facilities storing plutonium from dismantled weapons. An agreement was drafted on carrying out demonstration inspections. Negotiations have begun on other aspects of monitoring dismantlement.

In June 1995, the first shipment of lowenriched uranium delivered from HEU recovered from dismantled Russian nuclear weapons was received at the Department's Portsmouth Gaseous Diffusion Plant at Piketon, Ohio. Monthly deliveries to the United States have continued since then. The June 1995 deliveries were the first resulting from the historic February 1993 bilateral agreement between the United States and Russia concerning the disposition of HEU contained in excess Russian nuclear weapons. During 1995, the Department, working with an interagency team, continued negotiations with the Russian Federation on transparency measures to ensure that the low-enriched uranium being shipped to the United States from Russia under the Russian HEU Purchase Agreement is being derived from weapon-grade HEU. The second session of the Transparency Review Committee in July 1995 resulted in the signing of two, the initialing of three, and the drafting of nine annexes to the Protocol on Further Transparency Arrangements. The annexes govern monitoring activities in both the United States and the Russian Federation, where uranium subject to the February 1993 agreement will be processed or handled. Later, during the third session of the Transparency Review Committee in November 1995, the United States and Russia initialed all four facility annexes. These annexes outlined specific monitoring activities at Seversk and the Ural Electrochemical Integrated Enterprise (UEIE), where HEU metal from dismantled nuclear weapons will be converted and blended to lowenriched uranium, and at the Portsmouth Gaseous Diffusion Plant and U.S. fuel fabrication facilities, where Russian LEU shipped from UEIE will be fabricated into fuel for use in commercial power reactors. The annexes developed during 1995 pave the way for both special monitoring visits and permanent monitoring activities at processing facilities in Russia and the United States where material subject to the HEU Purchase Agreement will be processed.

\section{Strengthening the Nonproliferation Regime}

To strengthen nonproliferation worldwide, the Department of Energy has been working to-

- Increase the effectiveness of the IAEA safeguards and the international nonproliferation regime

- Encourage reform in unilateral nuclear export controls, while strengthening Nuclear Suppliers Group effectiveness by promoting expanded information sharing and analysis and by seeking adherence of key nonmember supplier states, such as China and South Korea 
- Promote regional nonproliferation measures, such as those under way in South America

Our successes in 1994 and 1995 were many. We committed ourselves to obtaining an indefinite extension of the Nuclear Nonproliferation Treaty, and in May 1995 we achieved that objective. With Argentina, Ukraine, and Chile now added to the list of signatories to the treaty, the Department began working with the Arms Control and Disarmament Agency to develop strategies to further increase the number of adherents. Among our numerous IAEA activities, we cooperated with many nations to strengthen international safeguards, supported inspections in Iraq, and also supported the agency as it addressed North Korean safeguards issues. As an outgrowth of the Gulf War, in Iraq the IAEA developed the " $93+2$ " program for detecting clandestine nuclear programs. We have provided key technology and policy support to this program. The denuclearization of the Democratic People's Republic of Korea (DPRK) was advanced through successful implementation of the U.S.-DPRK Agreed Framework of October 1994, governing the freeze on North Korea's nuclear weapon program. In support of this framework, we proceeded to clean up the fuel storage pool and are placing the spent fuel in canisters for safe storage.

With our development of the Nuclear Suppliers Group Information Sharing System, we achieved our goal of increasing that body's effectiveness. We also made substantial progress in the system's testing and demonstration phase. With the acceptance of South Africa, Argentina, and South Korea as members, the Nuclear Suppliers Group's numbers increased to 32 .
The Department negotiated and the United States signed bilateral export control agreements with Belarus, Ukraine, and Kazakhstan. A bilateral export control agreement is pending with Russia. The Department also developed a tailored work plan on export controls for all the countries that were formerly part of the Soviet Union. Experts from the Department's national laboratories began to work cooperatively with Russia's Kurchatov Institute on physical security, material accounting, and remote monitoring. In addition, the Department conducted international training on material protection, controls, and accounting and promoted and field-tested remote monitoring as a global monitoring tool with four global partners. We expanded regional nonproliferation activities in Northeast Asia, South Asia, Latin America, and the Middle East. In fact, the Department conducted the first-ever meeting of representatives of Egypt, Israel, Jordan, Oman, and other Middle Eastern states at a DOE laboratory to discuss the role of arms control, technology, negotiations, and verification in the Middle East.

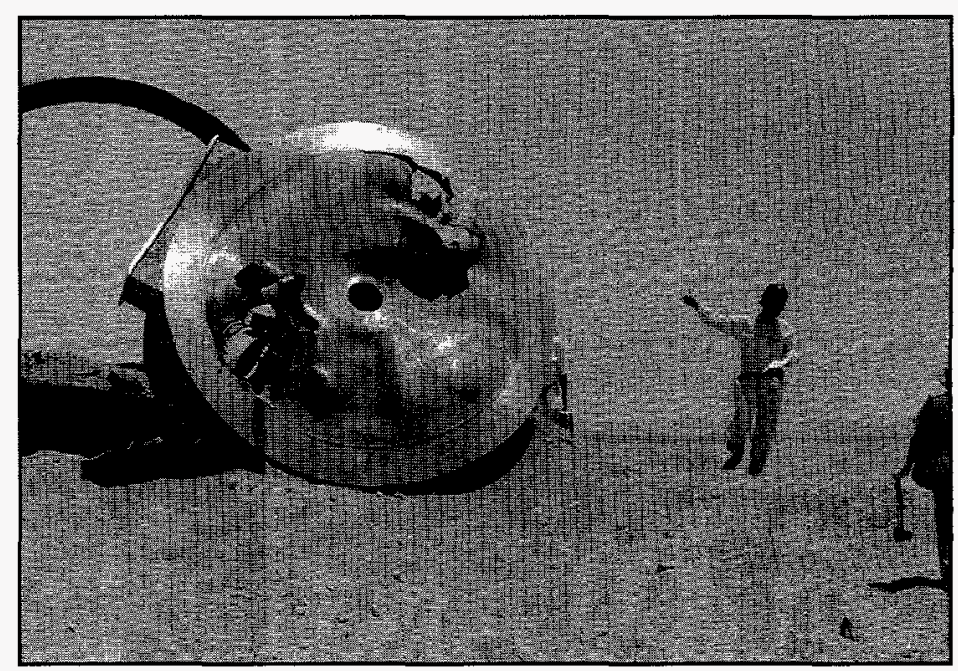

DOE personnel inspecting destroyed uranium enrichment equipment used in Iraq's nuclear weapons program. 


\section{Management of Surplus Fissile Materials}

In the aftermath of the cold war, significant quantities of weapons-usable fissile materials (primarily plutonium and HEU) have become surplus to defense needs both in the United States and Russia. The growing accumulation of these surplus materials poses both national and international security concerns. The safe, secure, and verifiable storage of these materials and their disposition in a manner that precludes reuse in nuclear weapons are essential to advancing U.S. nonproliferation and national security interests and to reducing the global nuclear danger.

In March 1995, the President directed that 200 tons of fissile materials be permanently withdrawn from the U.S. nuclear weapons stockpile. We have negotiated arrangements with the IAEA for international safeguards on 12 tons of HEU and plutonium at three DOE facilities. The Department is currently completing technical, schedule, nonproliferation, cost, and environmental analyses to provide the basis for building public and political consensus on the long-term storage of such materials and the disposition of weapons-usable fissile materials declared surplus to national defense needs.

We plan to issue a programmatic record of decision in early 1997 for the longterm storage of all weapons-usable fissile materials and for the technologies and systems to be used for the disposition of surplus plutonium. These efforts will result in an integrated plan for the safe, secure, cost-effective, environmentally responsible, and verifiable storage and disposition of surplus weapons-usable fissile materials.
We have separated the environmental analyses for HEU disposition from the broader programmatic environmental impact statement for surplus plutonium storage and disposition so that decisions on HEU disposition can be made on a faster track. The Department's preferred alternative is to blend down surplus HEU to low-enriched uranium for peaceful use in commercial reactor fuel. This will advance U.S. nonproliferation objectives, reduce stockpiles and associated safeguards and storage costs at our sites, and provide financial returns to the Treasury from the commercial use of the low-enriched uranium. We plan to issue the record of decision for the disposition of surplus HEU before the end of 1996.

The Department is also making progress in collaborative efforts with Russia to jointly develop technical alternatives for the disposition of surplus weapons plutonium. The President's Nonproliferation and Export Control Policy and the results of the January 1994 Moscow summit of Presidents Clinton and Yeltsin resulted in a commitment to jointly study options for the long-term disposition of fissile materials, particularly plutonium. The Department and the national laboratories lead the technical side of the effort for the United States. The joint study takes into account nonproliferation, environmental protection, safety, and technical and economic factors. Key objectives of the effort include providing decisionmakers from both countries with a set of consistently evaluated alternatives for plutonium disposition and for building further trust and cooperation in the area of fissile material disposition. The study is scheduled to be completed before the end of 1996 and will provide a good foundation for follow-on collaborative R\&D and small-scale demonstrations. 
The collaborative work of the Department and other agencies with Russia regarding fissile material storage and disposition is advancing U.S. nonproliferation objectives and providing a basis to support further cooperation in reducing the global nuclear danger.

\section{Naval Nuclear Reactors: 100 Million Accident-Free Miles}

The Department's joint effort with the Navy maintained its worldwide reputation for excellence and safety and reached a historic milestone in April 1994: 100 million miles steamed without a single reactor accident or nuclear harm to crews, the public, or the environment. The Naval Reactors program continues to be responsible for the operation of approximately 130 naval reactors while developing advanced components for the new attack submarine class. During 1994 and 1995, Naval Reactors continued design of the advanced fleet reactor plant for the Seawolf attack submarine, completed 25 percent of new attack submarine plant development, and conducted inactivation on five shutdown land-based prototype reactors.

\section{The Human Dimension of Our Changing Mission}

The end of the cold war and the reduced need for nuclear weapon production has affected the workers who had been dedicated to that industry. The mission of nuclear weapon production facilities, and therefore the workers' livelihoods, has changed dramatically and presented challenges to their communities as well. The Department is committed to fair treatment of those workers and communities.

Section 3161 of the National Defense Authorization Act for 1993 stated that, upon determination that a change in the workforce at a Department of Energy defense nuclear facility was necessary, the Secretary of Energy must develop a plan for restructuring that workforce. Such plans have been prepared for all sites undergoing restructuring. From the last month of 1993 through the end of 1994, plans were prepared for 10 sites. In 1995, the Department approved plans for two additional sites.

We minimized the disruption of affected workers' lives by maximizing the percentage of those who transfer, retrain, or retire within reasonable costs. Overall, we have been successful. Since the program began in late 1993, more than three-quarters of separations were voluntary across the sites completing workforce restructuring plans (see table on next page). In addition to the workers accounted for in the Transfer or Attrition column of the table, a total of 5,216 workers have been placed in other jobs at these sites, thus avoiding the need to separate them. Almost 1,700 of these workers were retrained in Department-supported retraining programs that facilitated their retention.

Through economic development initiatives, the Department also worked to help community-sponsored businesses compete, to increase the number of affected workers they employ, and to produce related community economic benefits. While community transition guidelines were being redrafted to reinforce business and job creation criteria, we expanded the program beyond economic development to provide job opportunities to separated workers. 
Management and Operating Contractor Employee Separations and Costs

\begin{tabular}{lcccccccc}
\hline Fiscal Year & $\begin{array}{c}\text { Early } \\
\text { Retirement }\end{array}$ & $\begin{array}{c}\text { Voluntary } \\
\text { Separation }\end{array}$ & $\begin{array}{c}\text { Transfer or } \\
\text { Attrition }\end{array}$ & $\begin{array}{c}\text { Involuntary } \\
\text { Separation }\end{array}$ & $\begin{array}{c}\text { Total } \\
\text { Voluntary }\end{array}$ & $\begin{array}{c}\text { Total } \\
\text { Costs }\end{array}$ \\
\hline $1993-1994$ & 1,090 & 2,827 & 632 & 1,242 & 5,791 & 78.6 & $165,375,910$ \\
1995 & 2,766 & 6,289 & 1,401 & 2,379 & 12,835 & 81.5 & $323,974,810^{\circ}$ \\
Total & 3,856 & 9,116 & 2,033 & 3,621 & 18,626 & 80.6 & $489,350,000^{\circ}$ \\
\hline
\end{tabular}

aEstimated.

Additional tools included retraining, job placement, and education programs to provide better near-term job opportunities, such as collaborative relationships between colleges and the Department that provide educational opportunities to employees affected by restructuring.
A survey of workers separated under the 1995 plans and amendments indicated that a majority of them were satisfied or very satisfied with the workforce restructuring process. A large majority of separated workers also indicated that the plan benefits were satisfactorily communicated. 


\section{ENVIRONMENTAL QUALITY WORKING TOWARD A CLEANER, HEALTHIER ENVIRONMENT}

In the quarter century since the first Earth Day, the United States has made substantial progress in protecting the environment and decreasing public health risks. Because energy production and use can significantly affect environmental quality and because past operations of the Department's defense-related facilities have left a legacy of unacceptable risks, the Department of Energy is centrally involved in efforts to solve domestic and global environmental problems.

To prevent the environmental legacy of the cold war from endangering the health and safety of this and future generations, the Department is engaged in a massive effort to understand and reduce the environmental, health, and safety risks at our nationwide complex of facilities. We also are working to resolve the Nation's long-standing concerns about the interim. storage and permanent disposal of spent fuel from the Nation's commercial nuclear reactors as well as defense wastes. And we are one of the principal players in U.S. efforts to work with the international community in protecting the global environment, especially in the area of potential climate change and other sustainable development agreements.

Our environmental quality vision for the Department is to-

- Fully incorporate improved environmental quality considerations in our daily operations and decisions to ensure no further degradation

- Fully understand the environmental, safety, and health risks at all Department of Energy facilities

- Manage, control, or return as much land as possible to alternative uses and ownership

- Be a world leader in environmental technology development and application

- Promote the use of cleaner energy and production processes

\section{The Challenge of the Cold War Legacy}

The greatest challenge facing the Department is to eliminate the risks and imminent threats posed by past

Departmental activities and decisions at the nuclear weapons facilities. Our Environmental Management program is responsible for both the short- and longterm disposal and treatment of nuclear and chemical wastes generated during nearly 50 years of nuclear weapons production at 137 sites and facilities in 33 States and 1 territory (see page 33). The overall efforts required to clean up the Nation's cold war environmental legacy are so extensive that it has been extremely difficult to estimate the total costs. We now estimate that the environmental management effort will cost $\$ 230$ billion over the next 75 years. Our efforts to date have taught us that significant cost savings 
will be realized through pollution prevention, development of win-win strategies with our stakeholders, and development of new technologies. The current budget for Environmental Management makes up more than a third of the Department's budget.

\section{Understanding the Risks}

In 1995, the Department turned the corner on addressing this complex and monumental cleanup effort and achieved tangible on-the-ground results. We shoveled more dirt and shuffled less paper. In previous years, much of the Department's Environmental Restoration program funding was spent on

\section{Environmental Management Technology Development Focus Areas}

Treat and Dispose of Mixed Wastes. The Department is pursuing versafile treatment methods such as plasma, vitrification, molten metal, and nonthermal techniques. These activities are being coordinated closely with waste management activities to meef Federal Facility Compliance Act requirements:

Retrieve and Process Tank Wastes. The Department is initiating full-scale demonstrations on technology systems to safely retrieve and efficiently process high-level tank waste for permanent disposal. Tank structural analysis and waste content analysis methods are being developed.

Remediate Contaminated Soils and Groundwater. The Department has initiated full-scale demonstrations on technology systems to characterize, contain, and remediate contaminated plumes in soils and groundwater. In-place treatment of dense nonaqueous phase liquids is one example.

Stabilize Landfills. Containment and in-place treatment methods for buried waste are being developed. Technology systems for retrieval, characterization, and trealment of landfill waste also are being pursued.

Stabilize, Decontaminate, and Decommission Facilifies. The Department will conduct a full-scale demonstration for the development of facility stabilization and decommissioning technologies that emphasize the recycling of materials. characterizing the contamination at more than 10,000 locations. We are now spending more money on actual cleanup work than on our legally mandated assessments and studies. Our draft report Risks and the Risk Debate: Searching for Common Ground provides a foundation of technical, environmental, financial, and social analysis that will help determine how costly it will be to stabilize and clean up the environmental damage.

We have established six priorities that cut across all activities of the Environmental Management program: address urgent risks, ensure worker safety, assume managerial and financial control, obtain on-the-ground results, focus the Department's technology development on the most pressing problem areas, and involve the public in decision-making. In 1994 and 1995, the Department made substantial progress in all these areas. We eliminated the three most urgent risks in the Nation's nuclear weapons complex: potentially explosive underground radioactive storage tanks at Hanford; corroding spent nuclear fuel at several locations, including Idaho and South Carolina; and unstable plutonium stored at the Rocky Flats site in Colorado.

We are also stabilizing nuclear materials at sites across our complex. At the end of the cold war, nuclear material production lines and reactor operations were halted in various stages, leaving nuclear material in various forms and packaging configurations. Collectively, these inadequately stored nuclear materials pose some of the highest risks in the country. Over the last year, we have stabilized more than 12,000 liters ( 3,200 gallons) of liquid uranium at the Idaho National Engineering Laboratory. We successfully started up the purification part of the F-Canyon at Savannah River to stabilize plutonium at that facility. Disposition of 26,500 liters (7,000 gallons) of plutonium nitrate at our Plutonium Uranium Extraction Plant at 

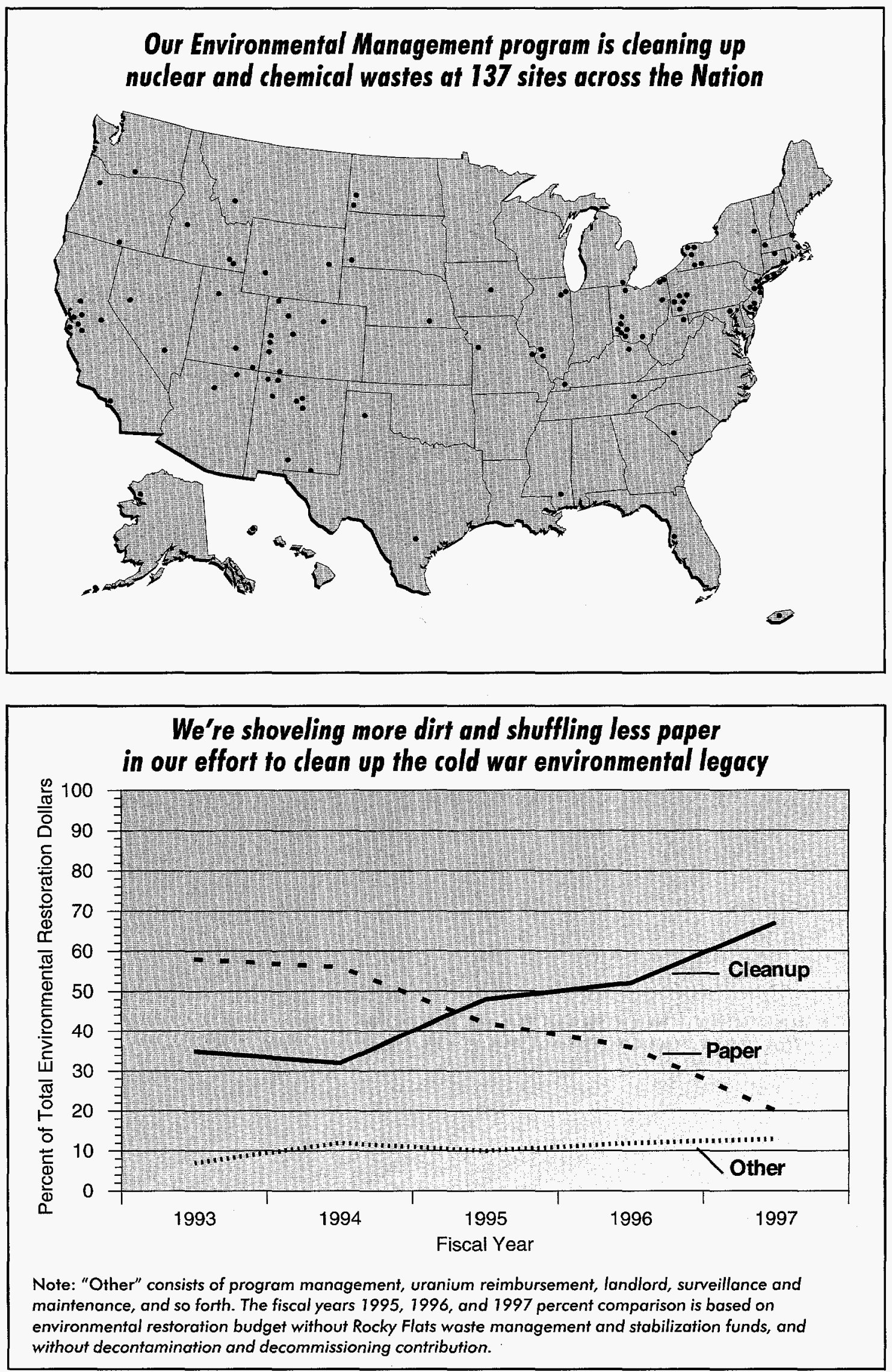


\section{Results From Coast to Coast}

From California to New Jersey, 69 of the Department's sites in 21 States that were contaminated with uranium mill tailings are being cleaned up by the Uranium Mill Tailings Remedial Action (UMTRA) Program. The UMTRA Program has completed remediation of 16 of 24 uranium mill sites that had been releasing radioactive radon gas, a known cause of lung cancer. The Grand Junction Project Office has successfully completed the remediation of 4,200 private homes and public buildings with foundations contaminated with uranium mill tailings used as fill and in mixing concrete. In 1994, the primary UMTRA contractor was awarded the National Safety Council's top award for establishing a new national standard for the best safety record in the United States.

Hanford was completed; and at the Idaho National Engineering Laboratory, 391 fuelhandling units were transferred to more secure storage.

We have also focused our activities on the Department's five major technology development areas by forming "focus area teams" made up of personnel from Headquarters and field offices, other Department of Energy programs, other Federal agencies, regulators, and other stakeholders. We have already developed a substantial portfolio of new or improved technologies that reduce risks to people and the environment, reduce cleanup costs, or provide cleanup methods that did not previously exist. Potential cost savings from use of new technologies are estimated to be between $\$ 8$ billion and $\$ 90$ billion, depending on the degree of cleanup.

\section{Reducing the Risks}

Approximately 85 percent of our Environmental Management budget goes toward compliance with environmental regulations and our agreements with States and the Environmental Protection Agency. We are working with our Federal and State regulators to find more cost-effective ways

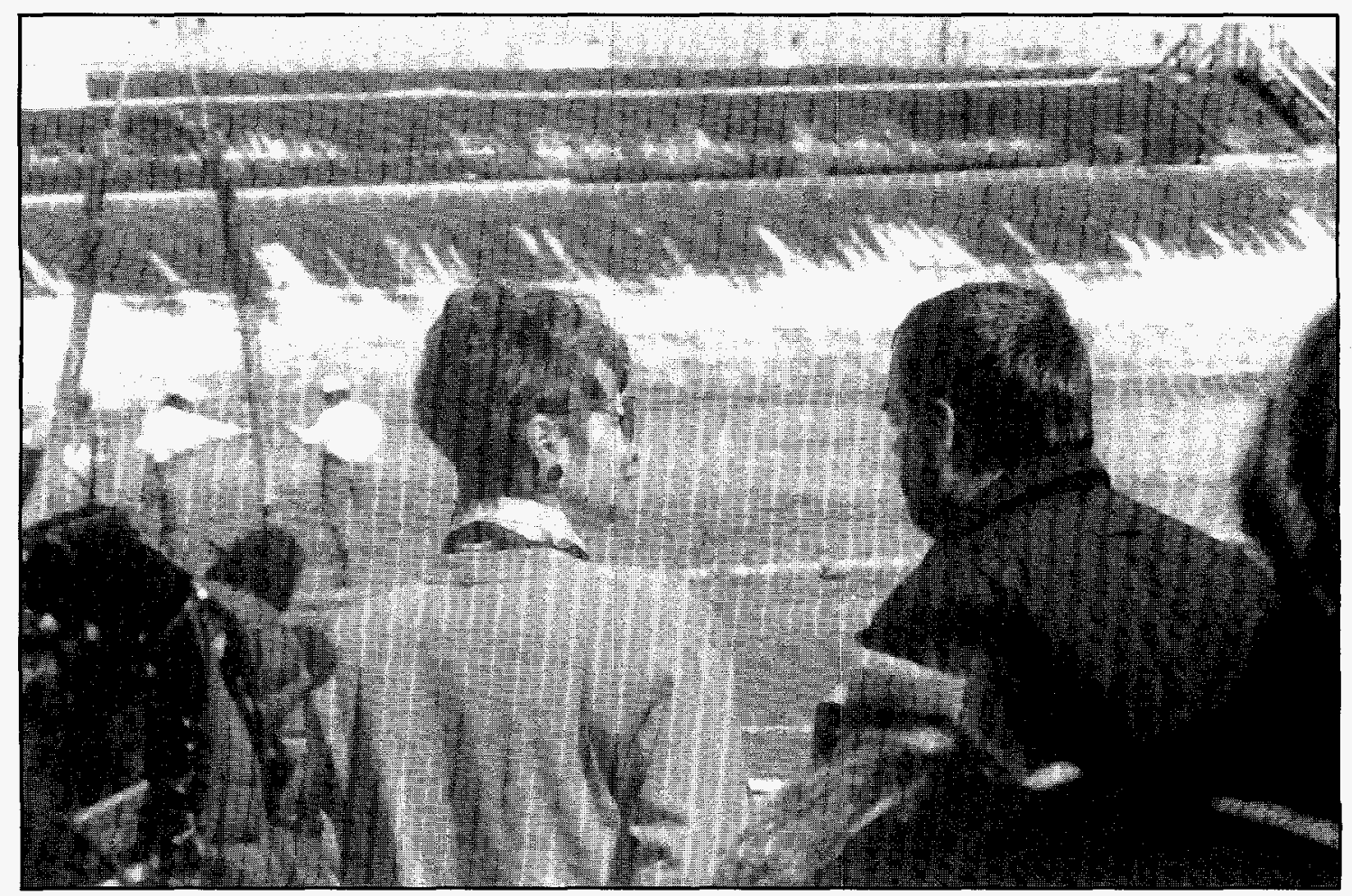

Secretary O'Leary attends a demonstration of sludge removal during her visit to the Rocky Flats Site in March 1994. The chemical operators are vacuuming sludge out of solar ponds as part of the environmental remediation effort. 
to meet our commitments, modifying existing compliance agreements as necessary to conform with budget constraints.

In 1994 and 1995, we completed the following: 106 remedial actions, bringing the total to date to 198 out of an original estimated total of $705 ; 237$ interim remedial actions; and cleanup at 9 Formerly Utilized Sites Remedial Action Program sites, bringing the total completed through 1995 to 21 out of 46 ; we also completed 9 decommissioning projects in 1994 and 17 projects in 1995.

We have safely placed in storage more than 500,000 cubic meters of high-level, transuranic, and low-level waste-enough to fill all the boxcars on a train more than 41 miles long-and treated 2.3 million kilograms ( 5 million pounds) of radioactive and PCB-contaminated mixed waste at the Toxic Substances Control Act (TSCA) Incinerator in Oak Ridge. We have now cleaned and responsibly managed almost 11 billion liters ( 3 billion gallons) of contaminated wastewater.

\section{Innovative Environmental Technologies}

Technology development is vital to the long-term success of our Environmental Management program. In some cases, there are no known solutions to cleanup problems. We are conducting a variety of applied research projects to develop more effective and less expensive remedies to the environmental and safety problems of the nuclear weapons complex. In 1994, the Department demonstrated, on a bench or full scale, more than 50 new or improved technologies, developed in partnership with the private sector, for treating environmental cleanup and waste management problems. We made available for private commercialization 24 new or improved technologies, including the Rapid Geophysical Survey and the Hybrid

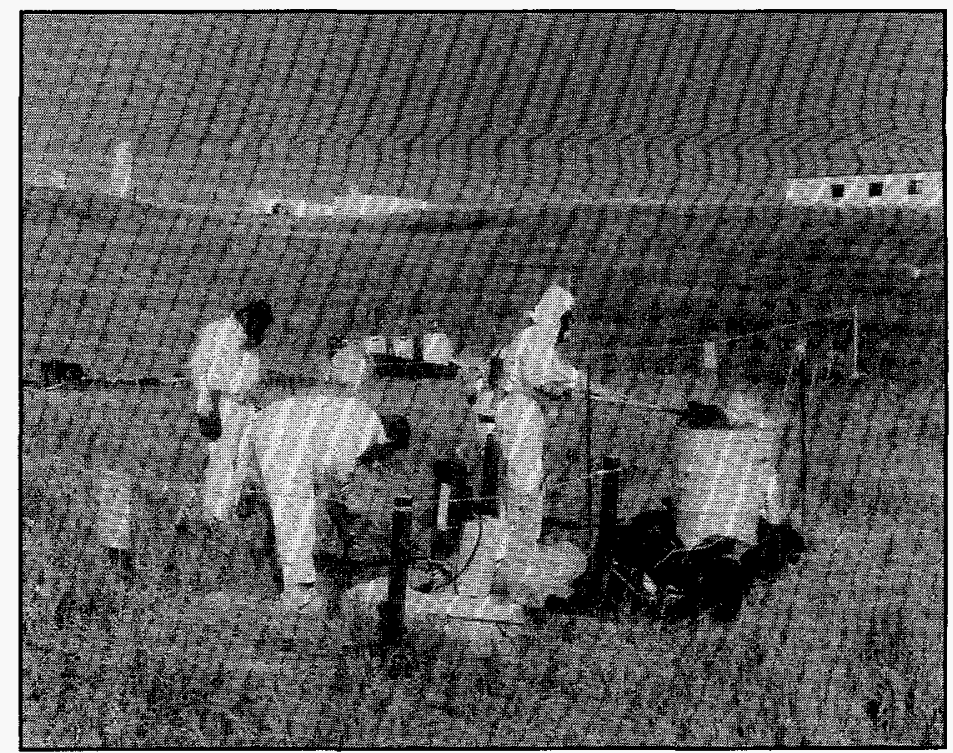

Technicians remove contaminated soil from high-priority site at Rocky Flats.

Directional Boring and Horizontal Logging Device. The Rapid Geophysical Surveyor can perform geophysical magnetic surveys 30 to 300 times faster than existing instruments at one-twentieth the cost.

In 1995 , we made 24 additional technologies available for transfer to the private sector. During the same time, the Department demonstrated another 50 environmental technologies at various stages of development. Thirteen innovative technologies were implemented on real Department of Energy cleanup projects in 1995. Among the technologies put to use for cleanup at the Mound Laboratory in Ohio was the Dig Face Characterizations system. This system is far faster than conventional environmental characterization processes, reducing workers' potential exposure to hazards.

\section{Efficiency Improvements in Environmental Management}

The Department is adopting "best in class" management practices to improve productivity without reducing planned environmental management and cleanup 


\section{Improved Contracting for Environmental Management}

Within the past 2 years, DOE has initiated competitions for contracts at Idaho National Engineering Laboratory, Rocky Flats Site, Nevada Test Site, Savannah River Site, and Hanford Site. Contractors have pledged savings of roughly $\$ 2$ billion in the two competitive procurements for Rocky Flats and Idaho National Engineering Laboratory alone. Both contracts contain incentives for economic development. The Rocky Flats contract rewards progress in site conversion. The ldaho contract includes commitments by the contractor to develop new cleanup technologies. Our new contracting policies also encourage Federal site managers and contractors to engage private companies and explore privalizafion opportunities.

at the sites. In 1995, the Department saved more than $\$ 2$ billion as a result of efficiency improvements. We are also privatizing some of our environmental management activities to reduce Federal costs. At Hanford, we have privatized lowlevel mixed waste thermal treatment projects and laundry services, for a projected savings of $\$ 630$ million.

We are reducing the size of our Headquarters offices and staff and completing difficult but necessary reductions of about 17,500 contractor employees across the complex. In all cases, these reductions are in compliance with worker transition requirements using early-out voluntary reductions in force, incentives, attrition, and partial hiring freezes, coupled with an expanded program of retraining. To ensure continued productivity improvements, the Department is recompeting contracts worth more than $\$ 28$ billion to implement fee rates based on performance, cost-saving incentives, and increased accountability for contractors.

To reduce the costs of maintaining our facilities, we are consolidating nuclear materials in fewer buildings, thereby reducing security costs and enabling us to close down old and inefficient buildings. We also have developed a systematic approach to identifying uncosted balances and improving funds management, thereby reducing unjustified carryover of uncosted balances from one fiscal year to the next.

\section{Building Consensus on Waste Treatment}

We have completed negotiations for 29 of the 35 site treatment plans for addressing the treatment of mixed radioactive and hazardous waste ("mixed waste") at our facilities in compliance with the Resource Conservation and Recovery Act (RCRA) and the Federal Facility Compliance Act (FFCA). These plans represent a 3-year collaborative effort among the Department, the hazardous waste regulatory agencies of the States, the Environmental Protection Agency, and the public.

The Department is ahead of schedule in treating mixed waste with thermal technologies at the Idaho National Engineering Laboratory. In addition, the achievement of three critical milestones in 1995 is enabling us to maintain our schedule for receiving waste at our Waste Isolation Pilot Plant in 1998.

For the cleanup program to ultimately succeed, the Department must gain the support of the public and local stakeholders in making economically feasible, technically sound, and publicly acceptable decisions on how the program is to move forward. One example of success in this effort is the Fernald Citizens Task Force, which was established in August 1993. The task force recommended that residual contamination levels match landuse levels and that certain low-level waste be stored at the site instead of being transported offsite. The task force determined that to leave soil that has radiation levels within acceptable risk undisturbed is more prudent than 
transporting it. Estimated savings resulting from this decision amount to more than $\$ 2$ billion.

We have set up advisory boards at Hanford, Idaho National Engineering Laboratory, Nevada Test Site, Monticello Site, Fernald, Oak Ridge, Rocky Flats, Savannah River, Los Alamos National Laboratory, Sandia National Laboratories, and Pantex Sites. Beginning in April 1995, the Department began a series of "budget work-out" sessions to address environmental activities under declining budgets. These sessions bring together senior Headquarters, field, and contractor managers and senior representatives of Federal and State regulatory agencies to find more cost-effective ways to meet environmental management commitments. The sessions have been held at Hanford, Savannah River, Rocky Flats, Oak Ridge, and the Idaho National Engineering Laboratory. One result has been the "Blueprint for Action and Cost Control at Hanford." This agreement, between Washington State, the Federal Government (the Department of Energy and the Environmental Protection Agency) and Hanford contractors, identifies a framework for implementing a more efficient and cost-effective cleanup program at Hanford under the Tri-Party Agreement. Those involved have committed to a partnership to improve environmental performance and create cost savings of more than $\$ 1$ billion at Hanford over the next 5 years.

\section{Pollution Prevention}

The Department has adopted a pollution prevention strategy to reduce the generation of all waste streams and minimize the impact of our operations on the environment. Preventing pollution reduces risks to the health and safety of workers and the general population. It also saves scarce financial resources by

\section{Processing Defense Waste}

Pretreatment of the 34 million gallons of high-level waste at DOE's Savannah River Site began in 1995 with the start of operations at the In Tank Processing Facility. The pretreatment is the first step in the immobilization of this waste in the Defense Waste Processing Facility, scheduled for operation in 1996.

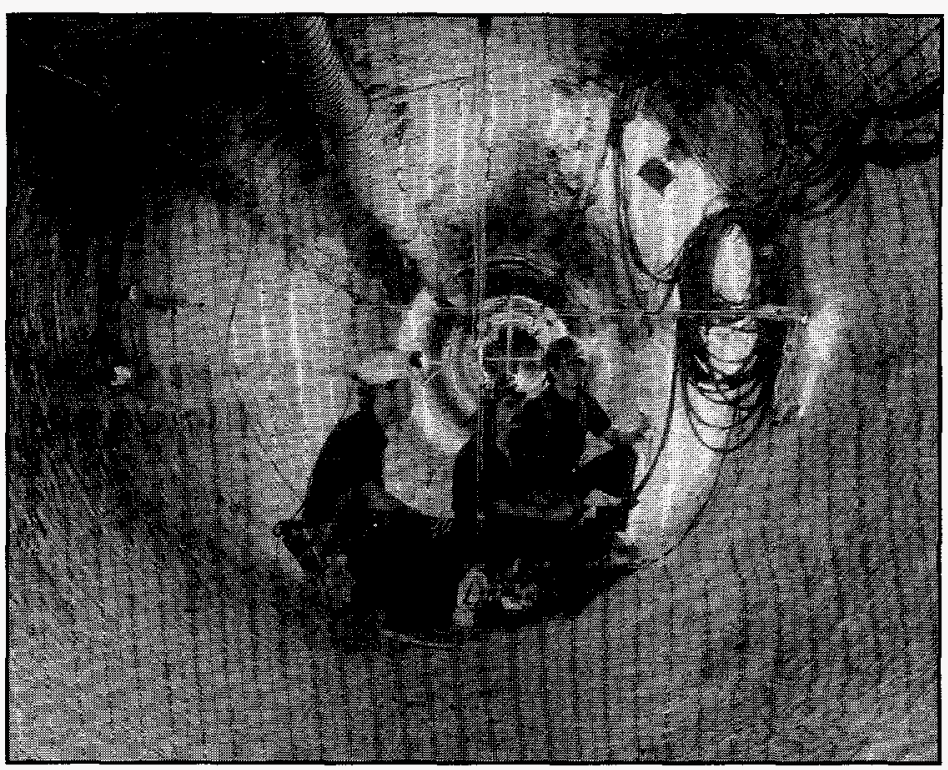

Waste Isolation Pilot Plant (WIPP) experiment operations personnel inspecting convergence gauges in an experimental room which monitors brine flow through clay seams that are present in the geology. WIPP, located in southeastern New Mexico, is a Department of Energy R\&D facility designed to demonstrate the safe disposal of defense radioactive waste in ancient saltbeds.

preventing or minimizing the need to clean up future waste. In 1995, the Department began 17 pollution prevention projects that will pay for themselves within 3 years.

An example of a pollution prevention project with a high return on investment is the elimination of radioactive waste at the Oak Ridge Y-12 Plant. Building 9995 of the Y-12 Plant currently has 19,000 square feet of floor area defined as radioactive material management areas. All wastes leaving the building are considered low-level radioactive waste for disposal. The pollution prevention project at this facility, initiated in February 1995, will reduce the overall size of the radioactive material 
management area to 2,300 square feet through work restructuring, decontamination, and relocating radiation area signs. The smaller area will mean less personal protective equipment will be required for work activities and most material leaving the building will not be considered low-level waste. The total project cost was $\$ 79,535$ and will result in annual savings of more than $\$ 1$ million.

\section{Disposal of Spent Nuclear Fuel}

For the Department's Civilian Radioactive Waste Management Program, 1994 was a turnaround year. We conducted a thorough programwide assessment and developed a new program approach that realistically aligned program technical work scope, resources, and stakeholder expectations so that critical milestones could be preserved and progress could be objectively measured. Congress supported the new approach by approving a 37-percent increase in program funding for 1995 compared to the 1994 level. The 1995 appropriation of $\$ 522$ million, along with improved program planning and enhanced

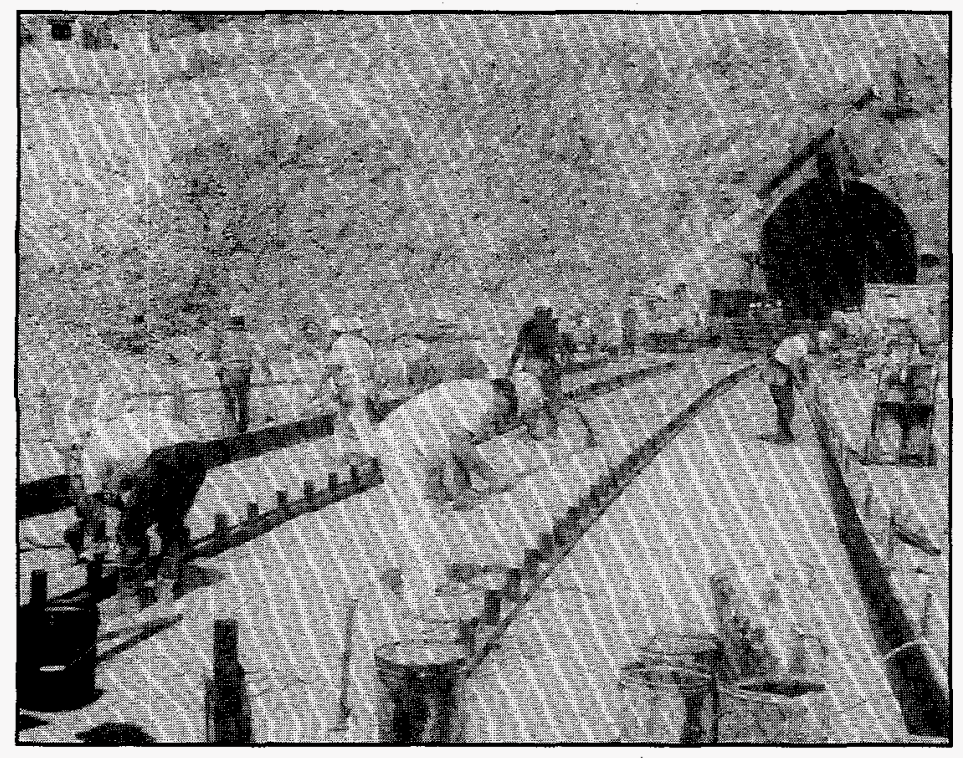

Construction activities outside the explaratory studies facility pad at Yucca Mountain. Research is under way to determine the site's suitability for a permanent repository of commercial nuclear waste. performance measurement, provided the foundation for successful implementation of the new program approach in 1995. Overall, 96 percent of the work planned for that fiscal year was completed.

Most of the funding increase was allocated to the Yucca Mountain Site Characterization Project. The project completed the year with accomplishments that often exceeded its targets, making significant, measurable progress toward a determination in 1998 of the viability of the site for a permanent geologic repository-a key objective of the new program approach. In the year following its initial shakedown in September 1994, the tunnelboring machine advanced into Yucca Mountain more rapidly than anticipated, completing more than 1 mile of the planned 5-mile tunnel loop. A new muck conveyor system, installed in July 1995, allows continuous removal of excavated rock and has increased the rate of tunneling and decreased the unit cost of tunnel construction. Three underground scientific test alcoves were also constructed to permit direct observation and in situ study of the site's geologic features. The advanced conceptual design for repository facilities progressed as planned, as did the waste package title I design. An assessment of total system performance concluded that the geologic setting at Yucca Mountain, combined with the engineered barrier system, could adequately contain and isolate emplaced high-level radioactive waste for tens, or even hundreds of thousands of years.

A second key element of the new program approach, the phased development of a multipurpose canister system for the storage, transport, and eventual disposal of spent nuclear fuel also proceeded on schedule and within budget during 1995 . The Department awarded a contract for design and certification of a multipurpose canister in April 1995, and a notice of availability of the Multipurpose Canister 
Environmental Impact Statement

Implementation Plan was published in August 1995.

Planned initiatives related to a third element of the new program approachenhancing the efficiency and costeffectiveness of program management and support activities-were also successfully implemented in 1995. Despite the significant increase in overall program funding, we held program management funding constant. An organizational realignment was completed, and major program participants were consolidated under the program's management and operating contractor. We encouraged earlier and more substantive involvement by program stakeholders through public meetings and other formal interactions. Three major documents were issued during the year to reflect the new program approach: the Civilian Radioactive Waste Management Program Plan, which described the strategy for implementing the new approach; a revised Program Cost and Schedule Baseline; and a new Analysis of Total System Life Cycle Cost of the Civilian Radioactive Waste Management Program.

The President's budget request for 1996 included $\$ 630$ million for the Civilian Radioactive Waste Management Program. The 1996 congressional appropriation of $\$ 400$ million, $\$ 85$ million of which is available only for an interim storage facility, and only upon enactment of specific statutory authority, precludes continued implementation of the program approach during 1996. In accordance with congressional direction, work at Yucca Mountain will focus on core scientific studies, and preparation and submittal of a repository license application to the Nuclear Regulatory Commission will be deferred. No funds are currently available in 1996 to prepare for interim storage or for development, beyond the design stage, of a multipurpose canister system. Within the present funding constraints, we are revising our strategy for advancing the program's mission.

\section{Environmental Justice Strategy}

The Department is also one of the major Federal agencies involved in implementing Executive Order 12898 on Environmental Justice, which requires Federal agencies to address the effect of their activities on human health and the environment for low-income and minority communities. Our Environmental Justice Strategy, which was approved by the President in April 1995, outlines our specific goals and approaches to reduce disproportionate negative impacts of our operations and facilities on these communities. As the first step in implementation, we established an environmental justice information clearinghouse to communicate with our stakeholders about our activities and resources for reducing or preventing adverse environmental impacts. A toll-free number for the Department's environmental justice information has been established. We are also cosponsoring with the National Institute of Environmental Health Sciences an Institute of Medicine study that will assess specific medical and health issues relating to environmental justice and establish appropriate priorities for medical research that would help improve our environmental and human health conditions.

We are also accelerating our waste management and cleanup activities to assist affected communities to improve their environmental and human health conditions. By cochairing the Interagency Task Force on Outreach for Environmental Justice with the Department of Defense, we facilitated the first interagency public hearing on environmental justice, held in January 1995 in Atlanta, Georgia. 


\section{International Sustainable Development Agreements}

Where global environmental risks call for international solutions, the Administration has been pursuing strong, fair, and balanced approaches in cooperation with other nations. The trend toward international agreements to protect the environment reflects both the transboundary character of the pollution damage and the need to establish environmental protection measures that treat trade competitors fairly. In the last decade, global agreements have been reached that address ozone depletion, climate change, biodiversity, and international shipments of hazardous waste.

The Administration has led international efforts to make the Framework Convention on Climate Change, entered into in March 1994, a strong and relevant institution. The first conference of the Parties to the Convention took place in Berlin in March 1995. At that meeting, the Parties agreed to U.S. proposals to begin negotiations on steps to stabilize atmospheric concentrations of greenhouse gases at levels that would not dangerously interfere with the natural climate system. They also agreed to start an international joint implementation pilot program that builds on the U.S. Initiative on Joint Implementation projects spearheaded by the Department of Energy and the Environmental Protection Agency (discussed in Chapter 1).

Under the Convention on Long-Range Transboundary Air Pollution of the United Nations' Economic Commission for Europe, the parties (including the United States) began work on a second-phase protocol to address the effects of nitrogen oxide emissions. Agreement was also reached to begin development of new protocols controlling persistent organic pollutants and heavy metal emissions. Because energy production and consumption activities contribute to all three categories of emissions, the Department of Energy participated in the U.S. representation and analyses. 


\section{ECONOMIC PRODUCTIVITY FUELING A COMPETITIVE ECONOMY}

Today more than ever, science and technology provide the foundation for the Nation's economic prosperity. The Department of Energy's unique scientific and technological resources within our vast network of programs, laboratories, and facilities continue to play an essential role in enhancing U.S. economic competitiveness. The Department's resources and world-class capabilities in key industrial areas such as energy and environmental technologies, advanced materials development, high-performance computing, advanced manufacturing, and biotechnology assist U.S. industries in sustaining economic growth.

Our vision is to use our leadership in energy, science, and technology to help industry sustain long-term economic growth that will create high-wage jobs and a cleaner environment. We envision that the Department will be sought by industry as an innovative and productive partner to make the U.S. economy the most productive in the world in its use of energy, material, and human resources. Achieving our vision will mean greater diversity in research and development $(R \& D)$ collaborations, greater resource efficiency and a shift from use of waste management to pollution prevention technologies, increased global usage and exports of technologies developed with Departmental support, and a cleaner global environment.

\section{U.S. Energy Technology Exports and Investments}

Global energy demand, fueled by economic growth in developing countries, is likely to increase by 40 percent in the next 15 years. As developing nations invest in new industrial infrastructure to fuel growth, there is an increasing emphasis on clean manufacturing processes, as well as interest in cleanup and waste management. Together with the Departments of Commerce and State, the Department of Energy is committed to increasing sales of clean U.S. energy and environmental technologies in countries with large, emerging markets and to promoting capital investments in such countries.

In keeping with those commitments, Departmental programs overseas are advancing sustainable energy development and creating jobs in the United States. In addition, Presidential and Secretarial missions on energy trade, investment, and sustainable development to India, Pakistan, South Africa, Russia, Brazil, and China were undertaken with great success.

Secretary O'Leary led the Presidential Mission on Sustainable Energy and Trade to India in July 1994. It was the first official visit by a U.S. Cabinet official to India in many years. The mission included one of the largest groups of business leaders in an 


\section{International Market Poiential for Energy Technologies, 1990-2010 (billion dollars)}

\begin{tabular}{lcc} 
Technology & Global Market & U.S. Exports \\
Electricity Generation & 914 & 94 \\
Oil and Gas & 955 & 110 \\
Efficiency & 252 & 17 \\
\hline
\end{tabular}

Sources: U.S. Agency for International Development; RCG/Hagler, Bailly, Inc.

official U.S. Government delegation. Another first was the inclusion of representatives of U.S. nongovernmental organizations. The mission began a new era for partnerships between the United States and India. A number of commercial deals were closed as a result of the mission, and several important government-togovernment agreements were reached on energy and environmental cooperation. Followup bilateral energy consultations in New Delhi in January 1995 produced a program of cooperation across all energy sectors that included environmentenhancing technologies. In June, a joint study by the U.S. Agency for International Development and the Department of Energy came up with eight ways to foster private investment in India's power sector.

Following up on the success in India, Secretary O'Leary led a Presidential Mission on Energy Investment to Pakistan in September 1994. An official delegation of more than 90 U.S. business executives, environmental leaders, and government officials accompanied the Secretary. The discussions again culminated in the signing of commercial agreements and in three joint statements of intent designed to encourage the bilateral exchange of information and ideas in the fields of energy and environment. In a December 1994 followup trade mission, then-Deputy Secretary White met with approximately 30 U.S. energy business executives in Pakistan to continue to promote opportunities for U.S. energy companies in the emerging markets of oil, gas, and coal. In April 1995, Prime Minister Bhutto of Pakistan met in Washington, D.C., with Secretary $\mathrm{O}^{\prime}$ Leary and participated in a signing ceremony for investment in Pakistan.

While in Florence, Italy, to give the closing remarks at the World Geothermal Congress in May 1995, the Secretary met with Italian Minister of Industry Alberto Clo and signed an agreement promoting joint energy R\&D and energy consultations. In addition, a roundtable discussion was held between the Secretary and the U.S. geothermal energy industry to discuss the $R \& D$ program and to make geothermal a cost-competitive energy resource.

In a project designed to diversify U.S. sources of energy supplies, the Department, together with Venezuela's Ministry of Energy and Mines, organized and hosted an energy symposium in Washington, D.C., for the Western Hemisphere's oil- and gas-producing companies. It showcased U.S. preeminence in environmental, production, exploration, and transportation technologies in oil and gas operations. The 3-day symposium began October 29, 1995, and attracted more than 400 participants.

Twenty-five Latin American countries were represented, as were U.S. and Latin American companies and the U.S. Government.

In June 1995, Deputy Secretary White led a delegation of representatives from 88 U.S. companies to Mexico City for a 4-day visit to meet with Mexican officials and Mexican private firms. The overall objective of the mission was to build new relationships between U.S. firms and private Mexican firms and government officials.

In August 1995, the Secretary led a delegation of some 80 energy companies, financiers, environmental groups, and government specialists to South Africa. The overall objective was to help the South 
African Government identify areas of cooperation in energy that will help it build a strong economy based on shared prosperity.

Throughout 1994 and 1995, the Department, working closely with the White House and other Departments and Agencies of the U.S. Government, provided energy policy assistance and other avenues of bilateral cooperation to Russia and the newly independent states. This assistance, designed to help the countries of the former Soviet Union make a successful transition to a free-market democracy, successfully laid the groundwork for tax and regulatory reforms that will eventually lead to new opportunities for U.S. energy companies.

\section{Industrial Resource Efficiency}

Partnerships between the Department and energy-intensive industries to develop research programs, strategies, and technologies will lead to dramatically improved energy and resource efficiency, as well as improved competitiveness. Through its Industries of the Future initiative, the Department works with seven of the Nation's most energy-intensive industries-petroleum refining, steel, aluminum, glass, metalcasting, forest products, and chemicals- to improve resource efficiency and energy productivity. Together, these industries account for 80 percent of energy demand (and waste) in U.S. manufacturing. Estimated cumulative benefits of the program through 2020 include a 4.3 quadrillion Btu reduction in energy usage, equal to the energy released by 1 million tons of TNT or more than 5 percent of the energy that this Nation consumes in a year, and 30 million metric tons less solid waste, equal to about 1 day's worth of U.S. industrial waste.

On May 1, 1995, more than 500 prominent government and industry leaders gathered in Washington, D.C., for the Department's

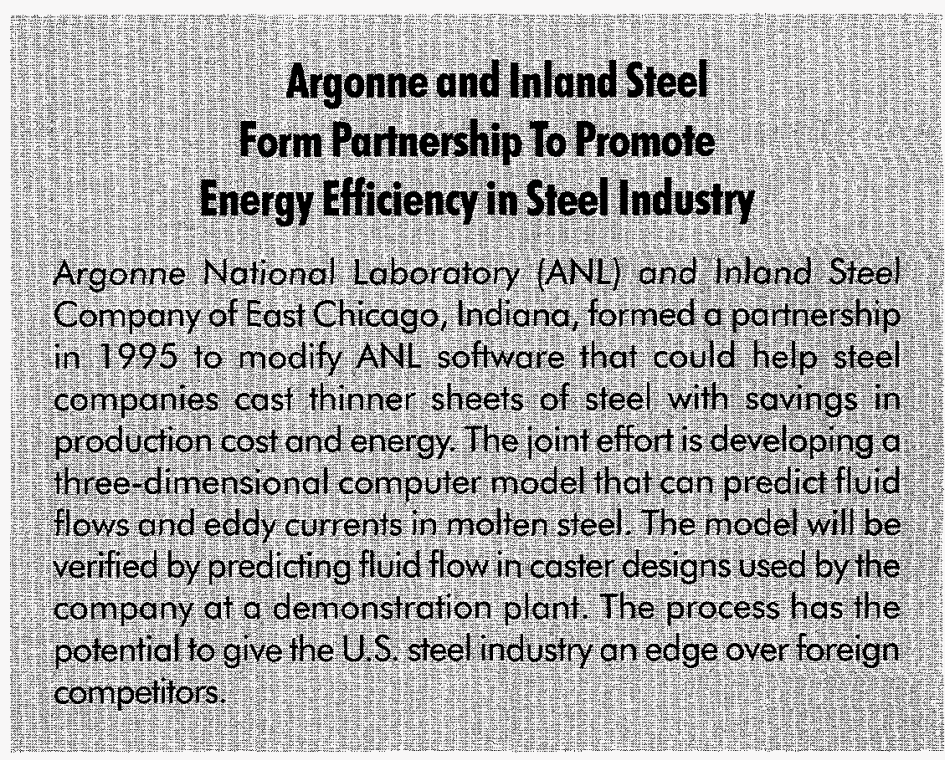

first Industrial Energy Efficiency Symposium and Exposition. The Expo was designed to launch new cost-shared partnerships with companies and industrial groups representing those seven energy-intensive industries. Each of those industries employs more than 250,000 people and is indirectly responsible for the employment of millions of others. The Expo featured a variety of workshops and more than 100 exhibits showcasing the latest industrial energy technology products, services, and R\&D.

Four industrial resource efficiency partnership agreements were signed in 1995. The first three agreements signed were with the pulp and paper, steel, and glass industries. And on October 25, 1995, the Department and representatives of the Cast Metals Coalition signed a collaborative agreement in support of the industry's "Beyond 2000: A Vision for the American Metalcasting Industry." The metalcasting industry's customers include the automotive, aerospace, railroad, construction, electric power, defense, and metal fabrication industries. These four agreements will ensure improved energy efficiency, a cleaner environment, and the creation of new jobs. 


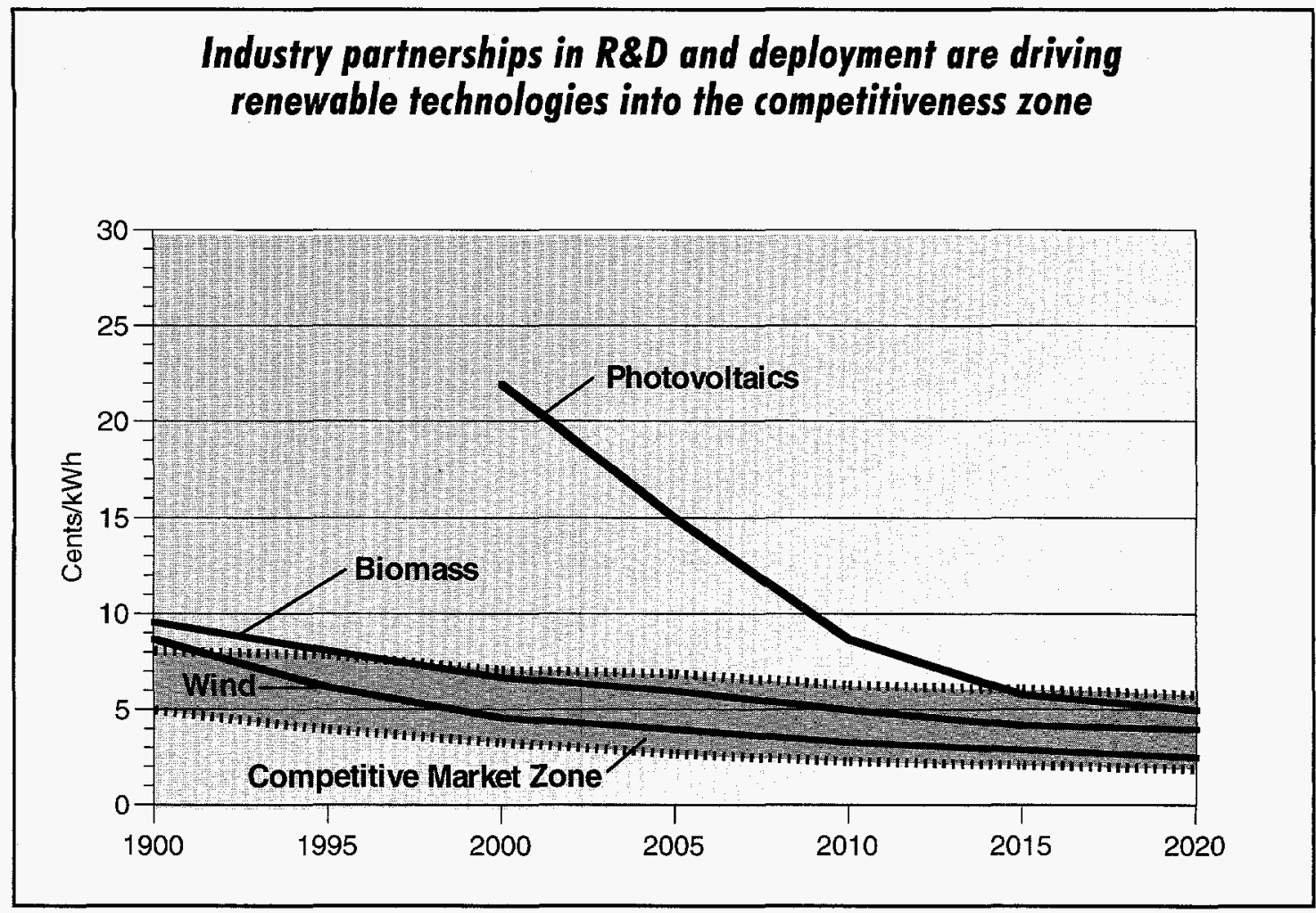

\section{R\&D Partnerships With Industry}

In 1994 and 1995, the Department placed a high priority on developing cost-shared partnerships. Collaborative R\&D in our four core mission areas forms the cornerstone of our economic productivity business line. Partnering with U.S. businesses, State and local governments, other Federal agencies, and the academic community produces dual benefits: We are strengthening the U.S. economy while expanding our scientific and technical knowledge base to accomplish our core missions.

The core competencies of our laboratory system have provided the basis for unprecedented growth in recent years in technology transfer partnerships between the Department and the private sector. Many of the partnerships that constitute this growth have already generated commercial products, improved U.S. industry's global market share, and created jobs. Partnering with industry is critical not only to ensuring the success of U.S. businesses but also to maintaining this country's long-term research base that will support tomorrow's applied R\&D. Privatesector R\&D in energy and energy-related fields has declined substantially over the past 10 years as industry has shifted its focus toward near-term development that generates commercial products in a shorter time. Collaborative efforts will help industry continue both long-term basic research and near-term development.

Cooperative research and development agreements (CRADAs) constitute one of the most successful partnership vehicles. In 1993, DOE had approved 333 CRADAs over a period of 2 years. In February 1994, we established an aggressive goal of signing 1,000 CRADAs by the end of 1995 . We actually reached this goal in August 1994 , more than a full year ahead of schedule. At the beginning of 1996, the Department had formed almost 1,600 partnerships through the CRADA process, involving more than 1,800 companies with 
a total research value of nearly $\$ 2.7$ billion. Industry has contributed more than $\$ 1.4$ billion toward this joint effort.

In 1995, the Department sought to increase its R\&D laboratory budget for cost-shared partnerships with industry. Despite the impact of budget cuts, the Department achieved this goal, with a 16-percent increase (from $\$ 283$ million to $\$ 327$ million). In terms of total laboratory $R \& D$, this is equivalent to a 19 -percent increase in terms of cost-shared partnerships as a portion of total laboratory R\&D.

In 1995, the Federal Laboratory Consortium honored the Department with 11 Awards for Excellence in Technology Transfer. The Consortium presents these awards to Federal laboratory employees who have done an outstanding job of transferring technologies to the private sector.

\section{Customer Satisfaction}

We conducted a survey in 1994 to determine our private-sector partners' level of satisfaction with the Department. Not content with the results of this survey, indicating that 80 percent of our privatesector partners were at least satisfied with the general value and service they received from collaborations with the Department, we established a goal for 1995 to increase industry's satisfaction.

A September 1995 survey of more than 500 technology partnership customers showed that 84 percent met the technical objectives they set for the arrangement and that 85 percent were satisfied or very satisfied with their overall experience with the Department and our services; 94 percent of respondents said they would recommend the Department as a partner, an increase from the 1994 total of 84 percent. The survey was based on responses to

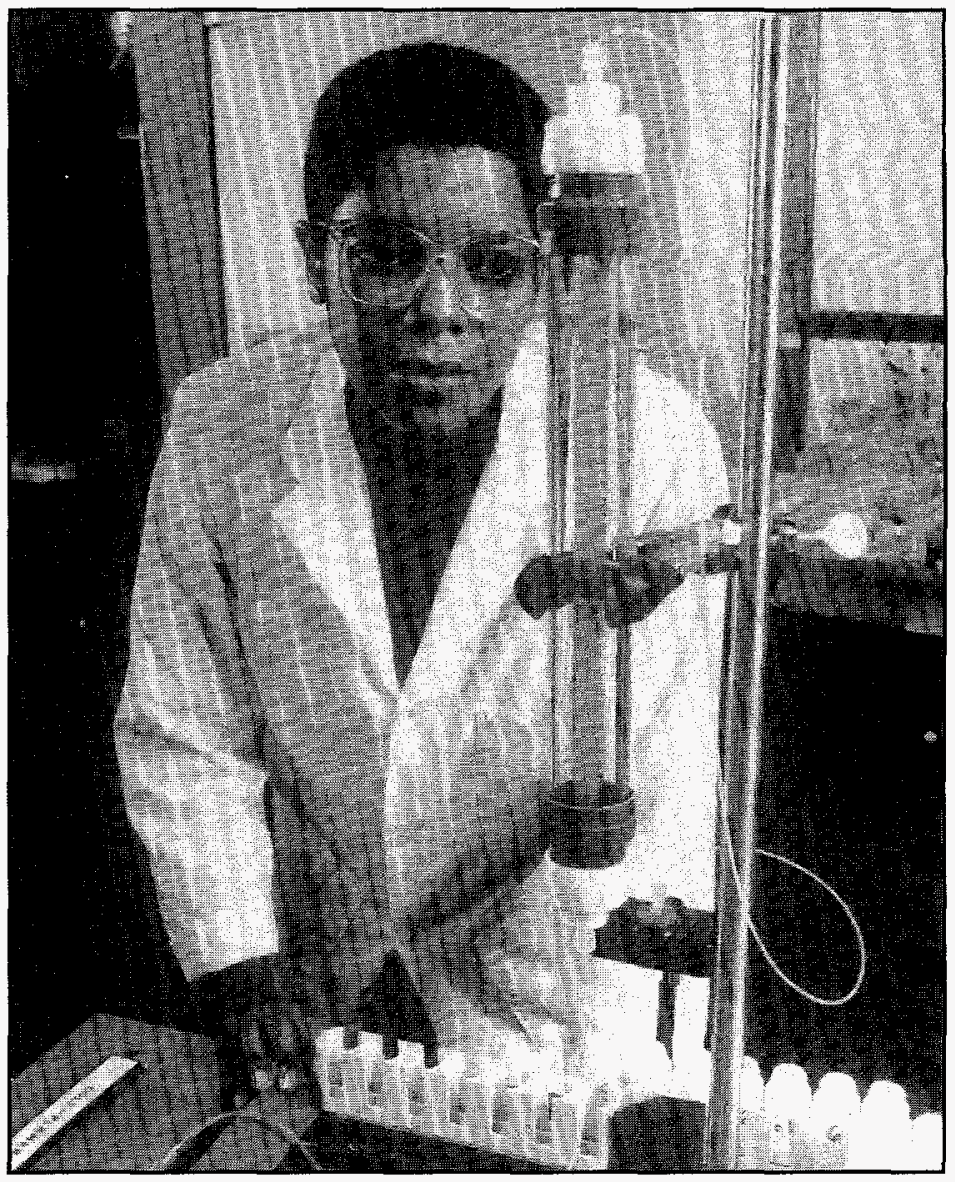

Brendlyn Faison, a researcher at Oak Ridge National Laboratory (ORNL), is leading a feam of ORNL researchers working with Ogden Environmental and Energy Services, Inc., to develop technology to be tested on contaminated water from a uranium mill tailings pond in Germany. The project is the first CRADA for environmental restoration between the Department and a foreign country.

questions on timeliness, objectives met, and overall satisfaction with Department of Energy collaborations. The customers represent a wide range of large and small companies, universities, and nonprofit organizations.

\section{Industrial Use of Department of Energy R\&D Laboratories}

The Department has made dramatic improvements in the contracting process over the past 2 years to facilitate technology transfer partnerships with the private sector. To reduce the contract 
processing time required for our

laboratories and facilities to enter into agreements to perform work for industry, one of our goals for 1995 was to eliminate or improve selected provisions and procedures in the Department's Orders. By taking such steps, the Department hoped to reduce the time required to process contracts by 25 percent of the 1994 baseline.

We achieved this goal by streamlining processes affecting the time for signing CRADAs. The average processing time at Department facilities was reduced by 49 percent, far exceeding the 25 -percent target. Field office reductions ranged from 24 to 77 percent. In addition, two field offices reduced the time required to process CRADAs to 1 day.

\section{Access for Small Business}

We also have promoted economic competitiveness within the small business community. The Department's Office of Economic Impact and Diversity instituted a Mentor-Protege Program that pairs small businesses with the Department's largest contractors. The Department also opened the Department of Energy Business Communication Center, which is open to all businesses but was designed to provide a one-stop information point for small businesses. 


\section{THE CRITICAL SUCCESS FACTORS ASSESSING THE WAY WE DO BUSINESS}

\section{Communication and Trust: Establishing an Open Relationship With the American People}

Under Secretary O'Leary's guidance, the Department of Energy is committed to establishing and maintaining a relationship with the American people based on communication and trust. We are moving from an atmosphere of secrecy and defensiveness-lingering habits of the cold war - to one of honesty and openness. Whether about past activities or current missions, we know that we must deal honestly and fairly with the public we serve and that communication is a two-way street. We are acutely aware that our activities directly affect the quality of life of each and every citizen.

Over the past 2 years, the Department has declassified thousands of documents, many of which have contributed to public discussion of complex issues, such as the ethics of early medical experiments to determine the effects of radiation. We have eliminated an extensive backlog of public requests for information. Our customers and stakeholders now advise us in many of the Department's policy and planning processes.

\section{The Openness Initiative}

Perhaps no single event better exemplified the Department's new attitude than the Secretary's

December 7, 1993, press conference unveiling a comprehensive plan to make the Department's facilities and information more open to the public. The press conference was the catalyst for a 2-year study across the Federal Government into past governmentsponsored experiments using radiation on human subjects - making information public and helping citizens locate the information in an unprecedented manner. The Department established an interagency telephone helpline in response to the enormous public demand for information. We have received more than 37,000 calls as of May 1996. The Department played a vital role in helping structure interagency searches for relevant documents and led all agencies in releasing these records to the public. We have made about 250,000 pages of documents (resulting from a search of 3.2 million cubic feet of records across the complex) available to the public electronically on the Internet, in our reading rooms, and in a central repository in Nevada. 
Known as the Openness Initiative, the comprehensive plan to make the Department's information more available to the public encompassed many efforts to declassify records and conduct policy reviews on this issue. Secretary O'Leary followed up her initial openness press conference with two press conferences, one on June 27, 1994, and the other on February 6, 1996, during which she announced significant declassifications and major policy initiatives related to openness. The Department is aggressively reviewing for declassification its holdings of classified records. In 1994 and 1995, we declassified 285,000 pages, and 337,000 pages, respectively. In 1994, we also began work on the Declassification Productivity Initiative to explore ways to automate the process of document declassification. In February 1995, as a major component of the Openness Initiative, the Under Secretary initiated the Fundamental Classification Policy Review, which is expected to result in major changes in classification policy.

In support of the Openness Initiative, the Department developed OpenNet, an Internet-based capability that enables the public to electronically search and retrieve all documents declassified and made publicly available after October 1 , 1994. In addition to these documents, OpenNet references older document collections from several Departmental sources.

OpenNet is one component of the Department's rapidly expanding Home Page - a "one-stop shop" on the information highway where the public can get instant information about Energy Department programs. The system brings together information from 50 DOE home pages for Headquarters, programs, and field sites. Unveiled on October 6, 1994, the Department of Energy's Home Page is another step forward in the Clinton Administration's initiative to make government information more easily available to the public. The Home Page is accessible to millions of homes and businesses around the world and in many U.S. public library systems by accessing DOE's Home Page address http://www.doe.gov. It provides general information about the Department of Energy, contact information, and pathways for finding and directly accessing information produced by the Department's staff and program offices, national laboratories, and other facilities. For example, the Department and its contractors are using the Home Page to establish a Purchasing System Benchmarking Clearinghouse as an on-line resource to ensure that "best in class" business systems and practices are available throughout the contracting complex. Our Home Page received 15,000 queries per week during the startup period in 1994-1995.

In 1994, the Department also established an electronic intergovernmental bulletin board, an on-line means of sharing information on the Department's participation in intergovernmental events. At present, only Headquarters is involved in providing information for and accessing it, but eventually the national laboratories, other Department facilities, and field offices will be included.

For many of our customers across the Nation and around the world, the Energy Information Administration (EIA) is their primary source for energy information, both on-line and off the shelf. EIA provides objective energy data for government, industry, and the public to foster sound policymaking and public understanding of energy issues. EIA has moved aggressively to make its energy data more available on the 
Internet and has established its own Web site as the primary means of electronic distribution of information. EIA energy information also is available electronically from the Federal Statistics Briefing Room, which is accessible from the White House's home page.

\section{Improved Services to Customers and Stakeholders}

Since Secretary O'Leary assumed her position at the Department of Energy, we have made a concerted effort to undo the unacceptably large backlog of Freedom of Information Act (FOIA) requests that existed at that time. Despite a 47-percent increase in the volume of requests, by the end of 1995, we had completely eliminated the pre1990 backlog and reduced the 1990-1992 backlog by 77 percent within Headquarters. We also increased case completions by 39 percent over the 1994 level. The average age of cases was reduced from 603 days in 1994 to 472 days in 1995, and requests were acknowledged within 2 days. In the spirit of openness, we have increased total grants (the complete release of requested information) by 94 percent over the 1993 level. There is also a FOIA home page, which includes the FOIA contact at each of our facilities and "how to" instructions on submitting requests.

\section{Public Participation}

In July 1994, Secretary O'Leary approved and issued a comprehensive Public Participation Policy to ensure that the business of the Department is "open to the full view and input of those whom it serves." More than 100 groups and individuals representing a broad range of public and privatesector interests contributed to development of the policy. The Public Participation Policy sets out the philosophy, goals, and core values on which the Department now operates. The policy promotes openness, early public involvement in the Department's decision-making processes, and employee empowerment.

One example is the Environmental Management Site-Specific Advisory Board, established on May 16, 1994. It currently has 11 site groups and, with stakeholders as board members, provides input and recommendations on Environmental Management's strategic decisions that affect future use of sites, risk management, economic development, and budget prioritization activities.

\section{Human Resources: Creating Meaningful Opportunities}

At the Department of Energy, our employees are our most valuable resource. Over the past 2 years, honoring our commitment to foster a workplace where teamwork, trust, openness, pride, and respect are standard, and where excellence and creativity are rewarded, we have made great strides in realizing the benefits of a diverse and talented workforce.

\section{Toward a Streamlined Management Structure}

The Department is reducing management layers and empowering employees to take greater responsibility and make more decisions. We completed a comprehensive reexamination of our organizational structure and staffing and improved our worker-to-supervisor ratio from 5.5:1 to 7.9:1 during 1995 . Twelve of our organizations reached a 10:1 ratio. 
We are using buyouts as a key downsizing tool in support of our Strategic Alignment goals. This program is being managed to minimize the need for involuntary separations, to protect diversity, and to allow for the acquisition of new skills to address the Department's changing missions and functions.

In 1994, the Department granted 600 buyouts. The highest priority for these buyouts was given to supervisors and managers at all grade levels and to employees in positions at or above the GS/GM grade 14 level. Second priority was for downsizing as a result of changing workload priorities. In 1995, the Department granted more than 700 buyouts; priority was given to meeting National Performance Review goals and downsizing needs in the Department.

Career counselors are providing Headquarters employees with assistance in dealing with the impact of downsizing and restructuring. Assistance covers a wide range of programs designed to help employees in changing jobs or career fields within the Department of Energy, moving to another Federal agency or to the private sector, starting their own businesses, or retiring. The centers provide job skill and interest evaluation, individual and career counseling, outplacement assistance, and relocation assistance. In 1994, 2,380 employees visited these centers. In 1995, the number of visitors rose to 2,912 .

There also was an increased use of career counseling and job information services. For example, in 1995 there were approximately 422 individual sessions with career counselors, and approximately 577 participants attended workshops or seminar sessionscompared with 300 individual sessions in 1994 and 121 attendees at workshops or seminars. We have also developed a comprehensive "how-to" resource guide and made it available to all Departmental site offices to help provide career transition assistance to our employees.

\section{Workforce Diversity}

Creating an atmosphere that fully uses the talents and capabilities of a diverse workforce is critical to achieving the Department's mission. In 1994, we issued the first-ever strategic plan for diversity, established the Secretary's Diversity Council, and issued a policy on diversity to all employees and managers. To foster diversity among our contractors, the Department worked with the Small Business Administration to allow credit against our 8(a) goals for the contract activities of these contractors. In addition, these contractors were authorized to award purchases of $\$ 3$ million or less on a noncompetitive basis to 8 (a) firms.

\section{Improving Human Resource Practices}

In keeping with the goals of the National Performance Review and Executive Order 12871, the Department is enhancing its ability to identify problems and craft solutions through the use of labor-management partnerships. In March 1995, Secretary $\mathrm{O}^{\prime}$ Leary and National Treasury Employees Union President Robert Tobias signed a partnership agreement for Department of Energy Headquarters. The Department has also entered into other local agreements at five field facilities with four different unions. We continue to hold monthly meetings with union representatives and have had an offsite session to develop mission and vision statements as well as to develop 


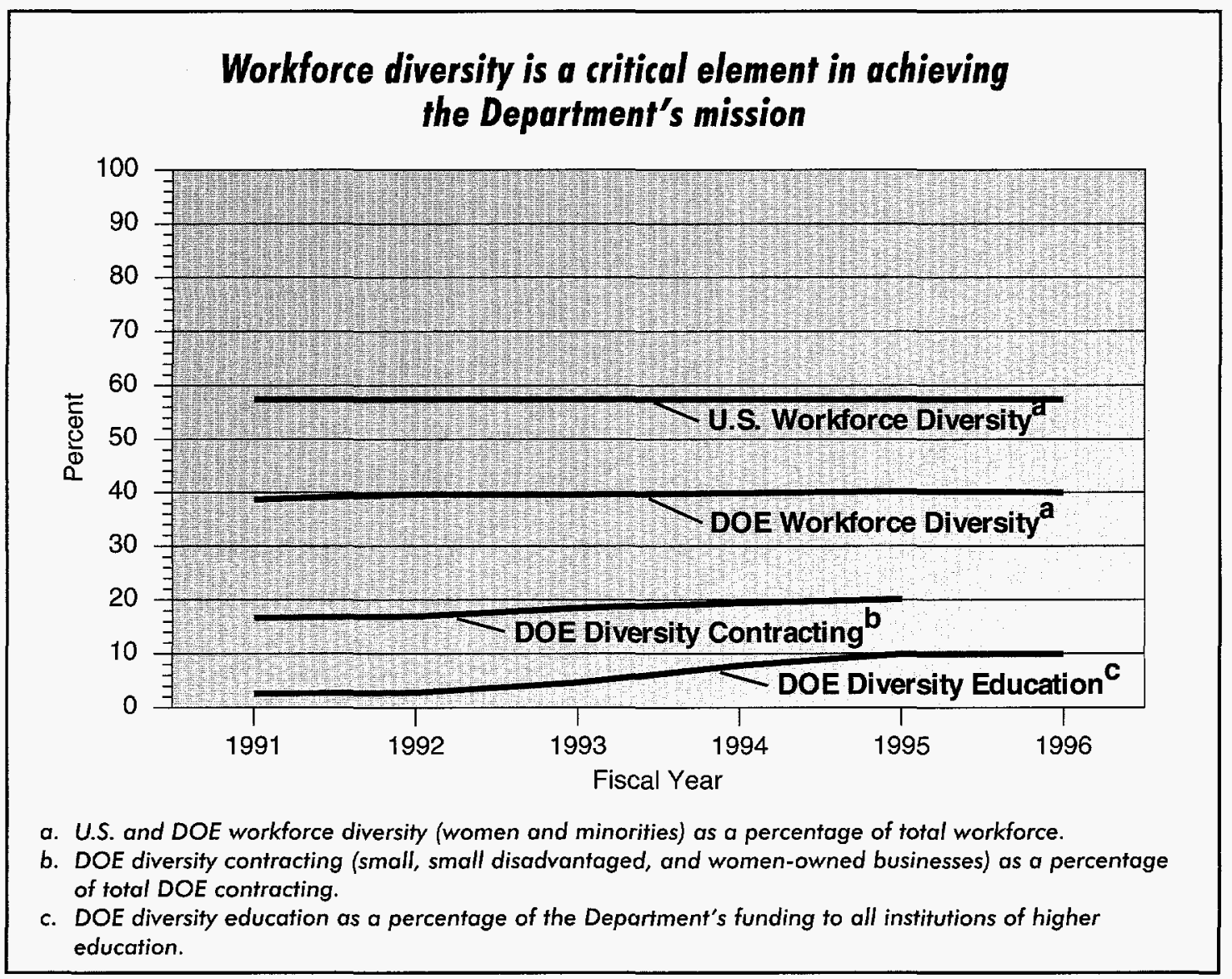

strategic goals and to outline a work plan that we are now implementing. Our new collective bargaining agreement will provide significant additional incentives for the formation of labor-management partnerships at the first-tier program element level. Taken together, these initiatives are expected to lead to more and improved labor-management partnerships.

Secretary O'Leary established an Employee Transition Plan in 1995 to coordinate various personnel and training projects, including retraining. The Department has issued guidelines on personnel, retraining, career development centers, and employee transition; conducted briefings on personnel and retraining issues; and instituted an individual development plan requirement. To support these efforts in a practical way, Career Management Resource Centers have been established in Headquarters and the field. Career counselors are now available to employees through these centers, and more than 1,000 employees have attended career planning workshops. The Headquarters centers have also sponsored private-sector job fairs with more than 1,000 employees participating. More than 50 percent of the Department's workforce has attended a special transition program called Moving Through Change. These new activities have been implemented while existing career development programs have continued.

The new appraisal system for the Senior Executive Service was successfully implemented July 1, 1994. During the first rating cycle, the annual 
performance of 407 executives was assessed. The Department received a favorable response from key managers and the executives on the revamped system, which focuses on effective leadership and program accomplishment. One of the key features of the system is the enhancement of effective communication and feedback between managers and their employees, as well as their customers, peers, and others involved in the work.

We have developed several tools to simplify and improve the operation of the current classification system. These include guides to help classify positions in streamlined organizations, generic position descriptions for certain leadership functions, and a clearinghouse of position descriptions for common Department of Energy positions. We developed generic position descriptions for about 30 percent of the approximately 5,000 Headquarters positions in the GS-1 through GS-15 grade range. These are currently available on computer diskettes.

Two Human Resource (HR) Partnerships are under way with customers. These include the HR/Environmental Management Team and the HR/Energy Efficiency Team. Both involve HR specialists being collocated with customers to provide easier access to HR expertise and to reduce the time required to process personnel actions. Employees' official personnel folders being onsite and the capability to process and print personnel actions are features of the Environmental Management partnering initiative. Customer reaction thus far has been very positive. The HR/Energy Efficiency Team is tracking cycle-time for typical personnel actions processed before and after the partnership was established. The results have been promising. For example, the total days to process a redescription of a job decreased from 7 days to 2 days. The results of these improvements in processing times will be expanded to other programs in the near future.

In August 1995, the Office of Human Resources issued An Employee Guide to Family-Friendly Programs in the Department of Energy as part of a continuing effort to respond to the President's July 11, 1994, memorandum directing all Federal Agencies to create a more family-friendly workplace. The guide explains in nontechnical language a variety of program options available to Department employees, including such options as flexitime, flexiplace, and family-friendly leave. Local personnel offices distributed copies of the guide and supplementary organizationspecific materials to all employees.

A major effort has been made to give the Department's managers greater flexibility to design and implement awards programs that support organizational, group, and individual goals. The Assistant Secretary for Human Resources and Administration has delegated broad program management authority to heads of Departmental elements and in June 1995 issued guidance on flexibilities available in administering awards programs. In accordance with revised Federal Performance Management Regulations, the Department modified its Performance Management System to allow further local development of innovative, value-added awards programs.

\section{Environment, Safety, and Health: Protecting Workers, the Public, and the Environment}

Excellence in environmental, safety, and health activities is critical to the success 
of each of the Department's businesses. The Department is responsible for the health and safety of tens of thousands of workers who participate in the cleanup and environmental management of former nuclear weapons facilities. We have shifted from a reactive approach to an emphasis on prevention and excellence in protecting worker and public safety and health and in achieving environmental standards. The Department is making significant progress in addressing its unique hazards, but we have much more to do.

\section{Groundbreaking Vulnerability Studies}

In 1994, the Department conducted groundbreaking "vulnerability" studies to identify the most serious hazards to workers and the public. These studies were the first Departmental overviews of major safety and health hazards across the complex. By the end of 1995, the Department had successfully addressed 299 plutonium-related vulnerabilities identified in our November 1994 Plutonium Vulnerability Study. A second study, published in December 1994, identified 33 chemical vulnerabilities and was accompanied by a management plan to address these vulnerabilities. During 1995, the Department implemented risk-based planning and budgeting at all operating elements to ensure allocation of personnel and budgetary resources to protect the environment and the safety and health of the Department's workers and the public.

\section{New Approach to Managing Hazards}

We began implementing a radical new approach to managing hazards at the Department's facilities - the "necessary

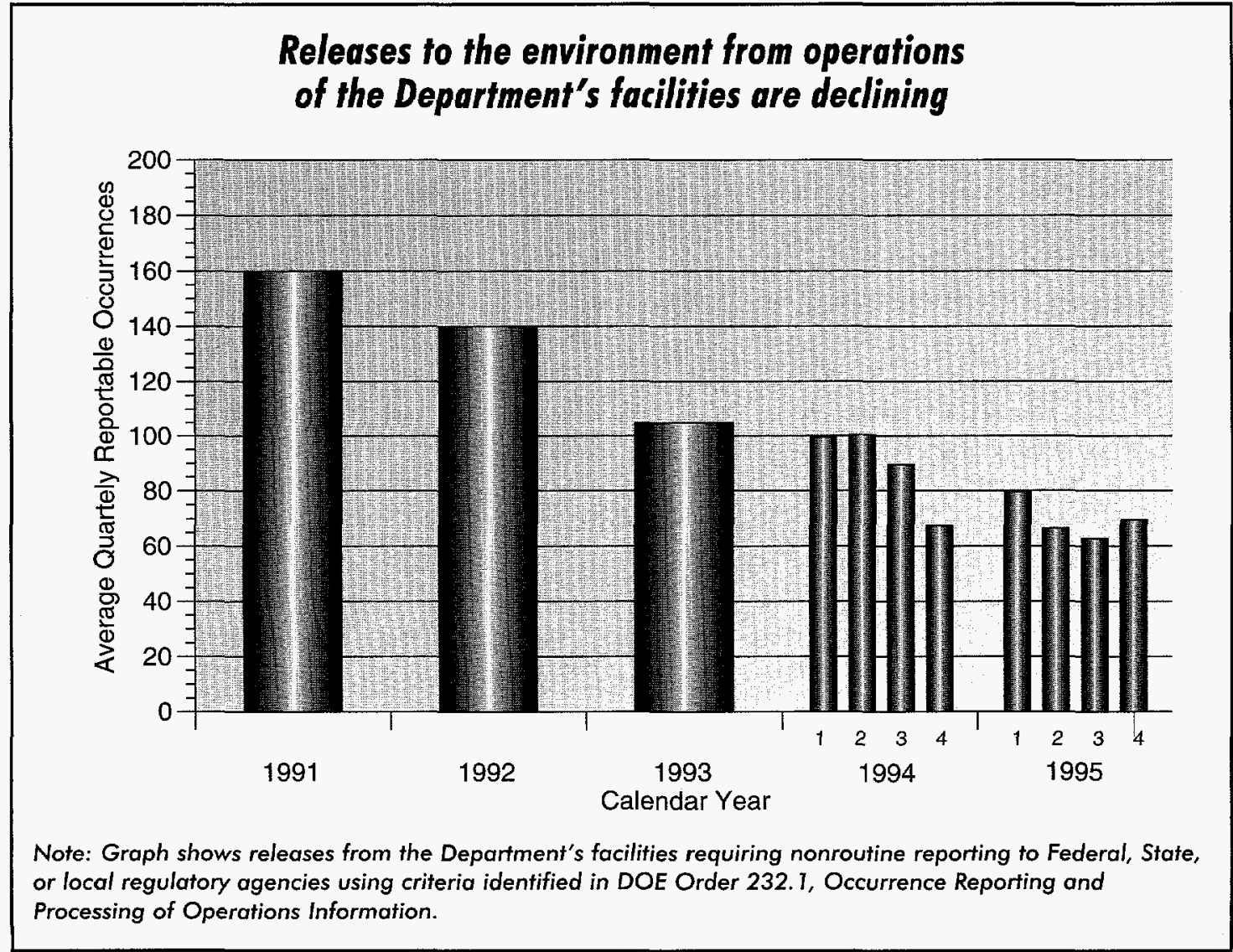




\section{The Department has made worker safety a critical measure of success}

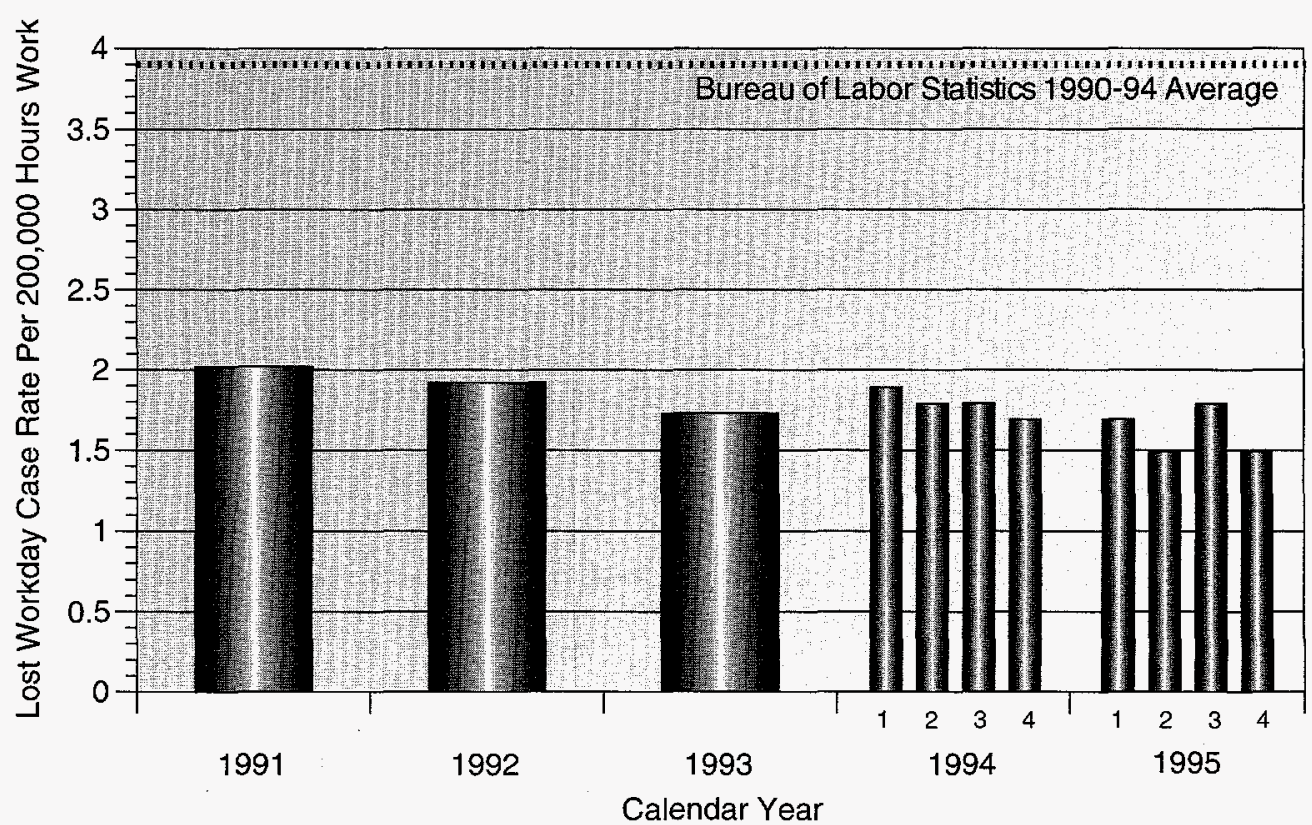

Note: Graph uses Bureau of Labor Statistics standards for reportable worker accidents. It includes industrial/ operational/production facilities only, and excludes Federal workers. The rate for 1995 is expected to increase as a result of revisions and later reporting.

and sufficient process." This approach focuses on work instead of paper. A team of experts at the site gets together and examines the work to be done, defines the hazards, and finds ways to perform the work while protecting health and safety. This results in greater efficiency, less bureaucracy and paperwork, and a safer workplace. Nine pilot projects were initiated in 1995, and final implementation of the process is expected in 1996.

\section{Streamlined Environmental Compliance}

In June 1994, Secretary O'Leary announced a new policy to improve the Department's procedures for complying with the National Environmental Policy Act (NEPA). The policy shift streamlines the NEPA process to work better, cost less, and increase public participation.
The new policy calls for innovative approaches to NEPA compliance, gives field organizations the authority to approve some environmental assessments and to issue findings, and supports a team approach to the review process. We established a goal to reduce process time for environmental impact statements from 33 months to 15 months, saving an estimated $\$ 26$ million over 5 years. The Department received the 1995 National Environmental Policy Act Quality Award for this effort.

\section{External Regulation of Department of Energy Nuclear Facilities}

In 1993, Secretary O'Leary called for external regulation of occupational safety and health at the Department of Energy. As a followup, Secretary 
O'Leary and Secretary of Labor Robert Reich signed a memorandum of understanding to study the costs, barriers, and benefits of making the Occupational Safety and Health Administration responsible for such regulation. Additionally, Secretary $\mathrm{O}^{\prime}$ Leary established the Advisory Committee on External Regulation of DOE Nuclear Facilities in January 1995 to examine the possibility of externally regulating all of the Department's nuclear sites. The Committee was provided numerous reports, analyses, briefings, and tours of Departmental facilities to support its deliberations. Its recommendations are expected in 1996.

\section{Management Practices: Delivering Best-in-Class Services}

The Department is embracing the best management practices available to improve internal processes and customer satisfaction, prevent defects, and eliminate waste. Employees have been empowered through integrated and open management systems that are results-oriented and cost-effective.

Customer expectations are intended to be met or exceeded. Contractor accountability is being increased.

\section{Strategic Alignment}

In response to the Administration's direction to all Federal agencies to streamline, the Department of Energy is reducing management layers and encouraging employee responsibility. Along with contract reform and performance measurement, these changes will increase accountability for results at all staffing levels. Programs are now aligned by "business lines" that represent elements of the Department's mission. Conducted along these business lines, strategic planning and program evaluation processes have

\section{By the year 2000, we will save U.S. taxpayers $\$ 10.5$ billion}

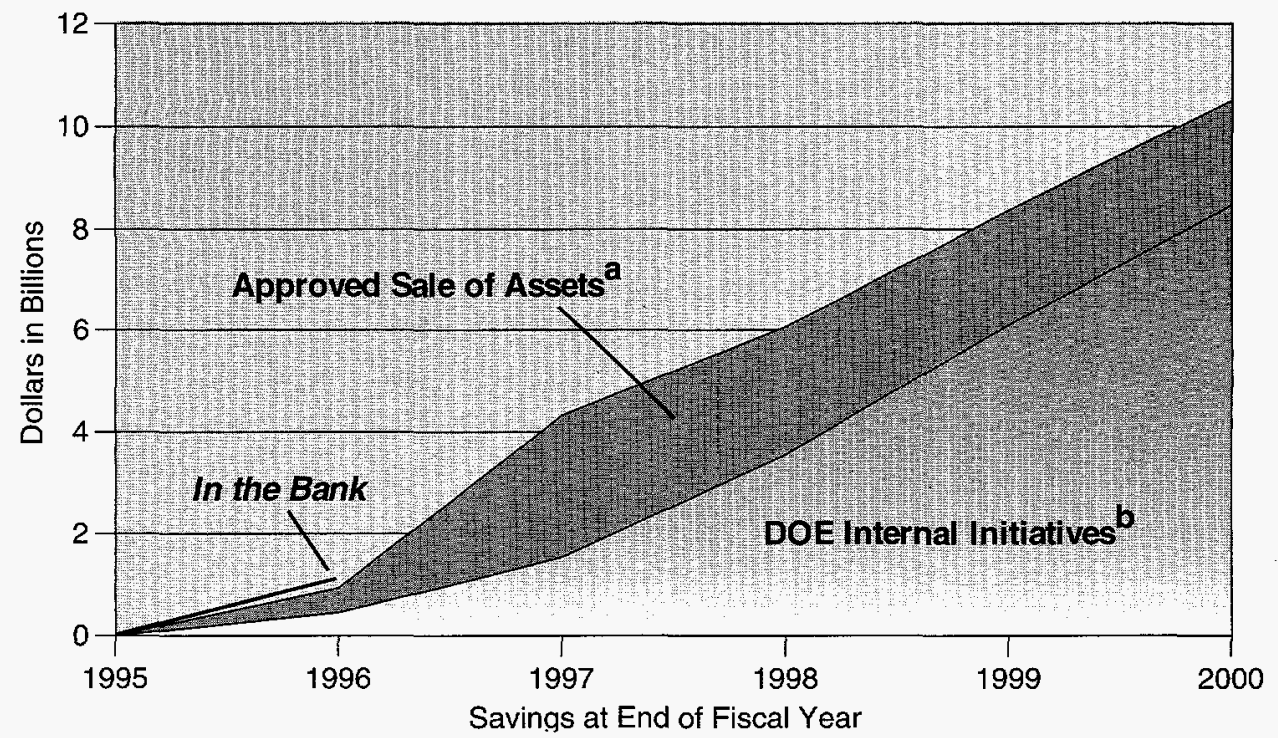

a. Naval Petroleum Reserves and highly enriched uranium.

b. Strategic Alignment, Yergin and Galvin task force recommendations, and weapons site cleanup and Environmental Management. 
become corporate activities that clarify our goals, priorities, and milestones.

The Department has made a concerted effort to realize efficiency savings throughout its programs, thus reducing budget requirements. From 1994 to 1996, our aggressive management initiatives have reduced budget requests by $\$ 2.1$ billion. These savings have been achieved through a combination of reductions in the cost of project management, reductions in contractor personnel, competitive efficiency improvements at sites, reduced overhead, and decreased support service contracting. Uncosted balances at year-end have been pared from \$2.47 billion in 1993 to $\$ 1.5$ billion in 1995 .

The Department's 5-year $\$ 1.7$ billion Strategic Alignment Initiative of May 1995 is ahead of schedule. Between May and December 1995, the Department reduced Federal staffing by 670 positions; reduced contractor staffing by 14,951 positions; closed its Laramie, Dallas, and Metairie offices; reduced support service contractor expenditures by $\$ 108$ million; saved $\$ 40$ million on travel; and reduced the number of Departmental Orders by 50 percent under the Accelerated Directives Reduction Effort.

The first year's implementation of 45 Strategic Alignment plans is expected to result in $\$ 277$ million in savings for 1996. During 1996, staffing levels will be reduced by 1,380 positions, 12 locations will be closed, overhead costs will be reduced by $\$ 180$ million, and the sale of excess assets will provide $\$ 15$ million to the U.S. Treasury.

\section{Contractor Accountability and Performance}

Most of the Department of Energy's budget is spent by contractors who manage the Department's extensive facilities around the country. In February 1994, Secretary O'Leary announced sweeping reforms in the Department's contracting system needed to carry out the Administration's effort to "reinvent government, make government work better and cost less." The contract reform measures are expected to save an estimated $\$ 5$ billion by the year 2000 . The reforms aim to reduce costs and make contractors more accountable in a multibillion-dollar management and operating system that has been operating on a cost-reimbursement basis, with payment to contractors based on costs incurred rather than results and an almost automatic contract extension. Among the specific accomplishments of contract reform are the following:

- Elimination of the "Federal norm" as the purchasing system standard for management and operating contractors and, in lieu thereof, reliance on best commercial practices

- Institution of "value-based selfassessment" programs to replace outmoded procurement and property oversight systems

- Elimination of Department of Energy and General Accounting Office involvement in protests between the Department's management and operating contractors and their subcontractors.

The overall result of contract reform has been the largest recompetition of contracts in the Department's history $\$ 28$ billion in 1995 alone, and $\$ 40$ billion over 5 years. The thrust of these competitions is a recognition that competition can be a valuable tool in achieving better contract performance, improved contractor management and cost-effectiveness, and high-quality environmental, safety, and health protection. 
Under the reforms, whether the contract is competed or extended, the Department also encourages management and operating contractors to focus on managing and integrating site activities, rather than on performing all site functions. The contract to manage the Idaho National Engineering Laboratory was the first to incorporate some of the reforms, including incentives for better performance and job creation through technology transfer. The most recent example is the 5-year management contract to run the Nevada Test Site, which contains resultsoriented, performance-based measures with incentives to achieve cost savings through increased efficiency.

Outsourcing and privatization are encouraged. Other management contracts signed in 1995 included the contracts at Rocky Flats, West Valley, Hanford, Kansas City, Oak Ridge, Argonne National Laboratory, Brookhaven National Laboratory, and the Thomas Jefferson National

Accelerator Facility.

\section{Reduced Costs of Litigation}

Another way the Department is making itself work better and cost less is by managing contractor litigation and, consequently, reducing legal fees. When Secretary $O^{\prime}$ Leary assumed Departmental leadership, the Department had been paying legal fees to contractors defending themselves in various class action suits with little or no Departmental review. She asked the General Counsel to do whatever was necessary to bring those costs under control.

On August 31, 1994, the General Counsel issued strict and specific guidelines to the legal counsel at the Department's operating field offices, severely limiting how much money may be spent and requiring close coordination of what contractors pay. At the Hanford facility, for example, the defense of cases involving 6 contractors was consolidated from 10 law firms to 2 . The legal fees for outside counsel in these Department of Energy cases, which had amounted to about $\$ 30$ million a year, dropped to about $\$ 25$ million during 1995, even though the number of cases increased from 281 to 407 . Overall, litigation costs for class actions dropped 21 percent from 1994 to 1995.

Savings were achieved in other litigation, too. Legal fees for non-classaction litigation cases dropped by 10 percent per case from 1994 to 1995 . Significant additional savings will be realized in the coming years as the full consequence of the guidelines - more effective and efficient management of cases from filing to resolution-shows up in the form of reduced litigation costs.

\section{A 50-Percent Cut in Internal Directives}

On September 30, 1995, the Department achieved a 50 -percent reduction in internal directives by transforming more than 100 prescriptive and costly DOE Orders into 21 streamlined, userfriendly ones. This reduction initiative was met a full year ahead of the goal established by the Administration. It not only reduced the volume of directives but also eliminated redundancy and overall burden while properly delegating authority and continuing to maintain worker and public health and safety at the Department's facilities. Additional benefits include increased stakeholder participation in the directives review process, enhanced electronic communication throughout 
the Department of Energy community, and clarified contractor requirements.

The Department initiated the Accelerated Directives Reduction Effort in March 1995. By partnering with internal and external customers, and through teamwork, trust, and perseverance, the Department achieved its ambitious goal of reducing internal directives by 50 percent. For example, the Office of Field Management created and used an effective new approach in consolidating 13 Orders. A process improvement team led by that office developed a performance-based set of management expectations for Federal managers. These managers can now use the expectations created to modify contracts for enhanced work results.

Our work continues. The Department is now pursuing additional reductions in both field and Headquarters directives.

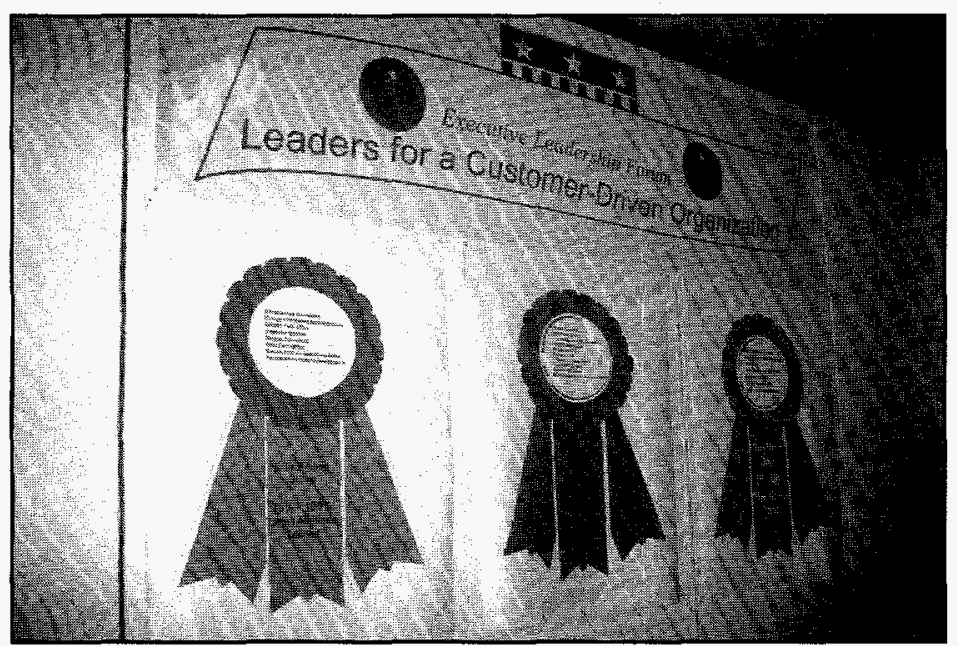

The Executive Leadership Forum is a $3^{1 / 2-d a y ~ w o r k s h o p ~ f o r ~ i n t a c t ~ t e a m s ~}$ of Departmental executives to accelerate leadership activities and skills for the transformation of the Department into a high-performing organization that is customer oriented, is mission and vision driven, and relies on the principles of quality management. The forum brings out the best in class. Blue ribbon status (75-100 percent of target audience trained) has been achieved by the following organizations: Albuquerque Operations Office, Energy Information Administration, Golden Field Office, Inspector General, Nevada Operations Office, Ohio Field Office, Quality Management, Savannah River Operations Office, and Southeastern Power Administration.
Field directives will be reduced by 80 percent in 1996, and evaluation of individual directive effectiveness continues throughout the entire Department complex.

\section{The Quality Transformation: Becoming a World-Class Organization}

Today, as the Department is called upon to deliver superior products and services with increasingly limited resources, the use of quality management tools is critical to our success in reinventing government. In response to calls from taxpayers for government that works better and costs less, the Department implemented a comprehensive quality transformation plan to demonstrate our commitment to the use of the proven principles of quality management to transform the agency into a world-class organization. The Quality Transformation: A Catalyst for Achieving Energy's Strategic Vision, introduced by Secretary $O^{\prime}$ Leary in March 1995, provides senior Department of Energy managers the key areas on which to focus for the Department to become a high-performance organization.

Six Department-wide goals were established following completion of a baseline assessment that made use of the criteria included in the Presidential Award for Quality, the public-sector equivalent of the prestigious Malcolm Baldrige National Quality Award. With facilitation by the Office of Quality Management, Departmental managers established goals and objectives for improved performance in the following areas:

- Information and analysis

- Human resource development and management

- Leadership 
- Process management

- Customer focus and satisfaction

- Strategic quality planning

The use of quality-improvement tools designed to achieve these goals has resulted in better performance. By using the Quality Transformation Plan to focus our efforts, virtually every part of the Department has significantly increased customer satisfaction, improved productivity, and reduced costs.

Customer satisfaction is a critical measure of performance. In January 1994, we conducted a Department-wide survey of 1,200 of our customers to obtain baseline data of customer satisfaction. We found that, overall, the Department is recognized as an excellent service provider, with 73 percent of the respondents indicating that they were satisfied or very satisfied with our products.

We continuously search for ways to improve customer service, including personnel and process management changes. For example, approximately 800 mid-and upper-level Department managers completed the "Leaders for a Customer-Driven Organization" training in 1995 to secure the leadership skills necessary for transforming the Department into a high-performance, customer-oriented organization. We have also focused on identifying activities that could be reengineered to provide meaningful results and meet customer requirements. Tangible results include the previously discussed NEPA process improvements that will save $\$ 26$ million over 5 years.

We have been recognized with numerous quality-related awards, including the National Performance Review Hammer Awards mentioned in the Introduction. The Quality

\section{We are striving to increase customer safisfaction-and we are succeeding}

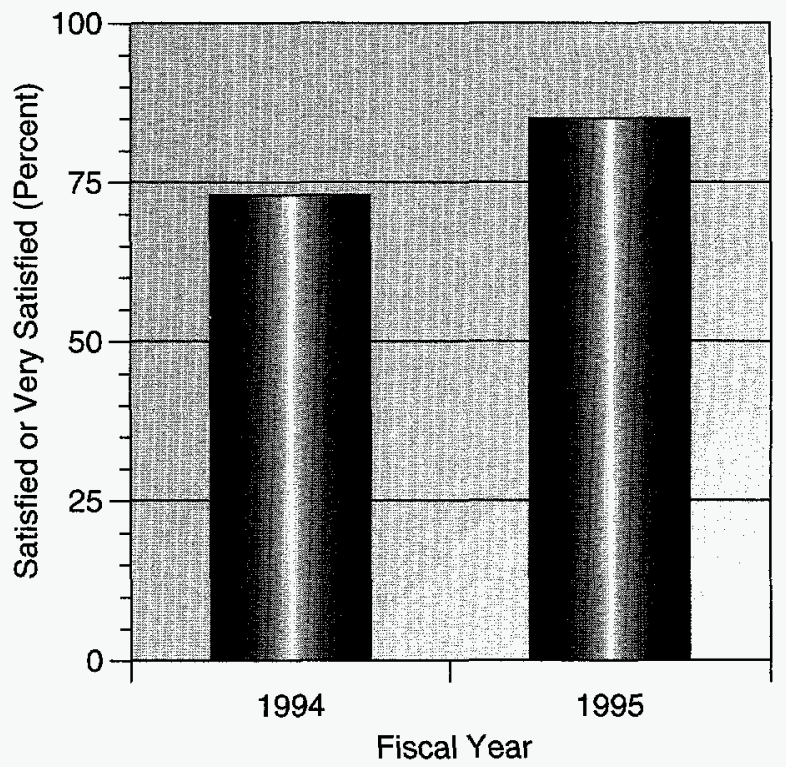

Note: 1994 data based on a survey of 1,200 customers complexwide. 1995 data based on surveys conducted by 7 Department of Energy organizations of a total of 1,130 customers. Future Departmental surveys will include standard questions and collect complex-wide data biannually.

Transformation Plan has been key to helping us achieve the results that have earned us such recognition and to our becoming a world-class organization.

\section{Alternative Uses of the Department's Lands and Facilities}

Stewardship of a vast complex of facilities and land assets is a major role of the Department. We believe that stakeholder involvement is necessary to determine the alternatives for the best use of these lands and facilities. In December 1994, we announced our new policy to directly involve our stakeholders in this process; and by the end of 1995, we initiated six major actions in conjunction with the general public and our field offices to make the 
Department's land and facilities available for broader public use. For example, the Nevada Operations Office is increasing tribal involvement in its sitewide environmental impact statement process for the Nevada Test Site. Another example of our extending the use of our assets is the privatization of the power production and transmission facilities at the Savannah River Site near Aiken, South Carolina. Actions such as these will provide the public, our customers, the best alternative uses for our valuable assets as well as the input to make them happen.

\section{Privatizing Assets}

The Department of Energy has an interest in privatizing those of its activities and assets that are more appropriate to the private sector than to government. In its first privatization initiative, the Department has been successfully transferring the operation of its uranium enrichment facilities to the United States Enrichment Corporation. This ongoing change is maximizing the value of the uranium enrichment complex to taxpayers and ensuring a long-term domestic supply.

The Department has proposed legislation to privatize the Government's share of the Elk Hills Naval Petroleum Reserves. While these privatization efforts are under way, we are also making significant progress in improving the efficiency of these operations, saving taxpayer dollars. For example, a cogeneration plant completed at the Elk Hills field (and discussed in Chapter 1) is saving nearly $\$ 14$ million per year by generating onsite electricity and earning another $\$ 2$ million annually by selling excess electricity.

The Department is selling many of its material and land assets, including precious metals that have been stored for years - with the proceeds returned to the Treasury. Many of these efforts offer multiple benefits. For example, we are working with the United States Enrichment Corporation to blend down excess highly enriched uranium inventories so they can be sold as fuel for commercial reactors. This reduces our costs for safeguarding the uranium, while helping to satisfy our nonproliferation goals.

At our Hanford Site, we have embarked on the largest privatization effort in the history of the environmental cleanup program. We are moving forward with plans to select one or more private companies to design, finance, build, own, and operate plants to treat and solidify 56 million gallons of radioactive and hazardous waste stored at Hanford. By guaranteeing these companies a steady waste stream and a fixed price per unit of waste, the Department will ensure progress on this complex, highpriority task - timely reduction, without undue burden to taxpayers, of a major risk remaining from cold war weapon production. These changes make good economic sense. Our privatization efforts recognize the appropriate role of government and contribute to reducing the national deficit. 


\section{WE CHANGED OUR PRIORITIES PROCEEDING WITH OUR GOALS AND COMMITMENTS}

Following his election in 1992, President Clinton noted that the Department of Energy's future demanded a different direction and a different policy. His energy priorities were "greater reliance on American natural gas, greater energy efficiency, greater development of alternative resources, a greater commitment to making good energy policy and good environmental policy good economic policy for America." Secretary O'Leary's major task then was to redirect the Department of Energy in these priorities.

Her proposed 1994 budget, sent to Congress in April 1993, was one of the first reflections of her changed priorities for the Department. These changed priorities led to significant progress toward achieving the key goals of improving the Nation's economic productivity, reducing the nuclear danger, enhancing energy security, protecting global environmental quality, improving the Department managerially, and increasing public trust in government. After decades of an old culture focused on building weapons, the Department shifted to its post-cold war role as a major contributor to the Nation's economic vitality.
The unprecedented strategic planning process and strategic alignment begun in 1994 were major steps toward achieving the new vision set for the Department by Secretary O'Leary. We actively pursued meaningful involvement of our stakeholders, and surveys of our customers indicate we are achieving results. As we proceed with the goals and commitments established for 1996, we are also revisiting the strategic plan to ensure that it remains consistent with the overall goals of this Administration. As we look toward 1997 and beyond, we will continue to use quality management tools to set expectations and measure our results against our strategic plan.

While the long-term scope of the Department is still evolving, we now have a greater sense of the future. We demonstrated our ability to adapt to a changing world. And while the world may continue to change, we are confident that the missions we now perform will remain vital to the Nation and that we will be successful in carrying them out. 